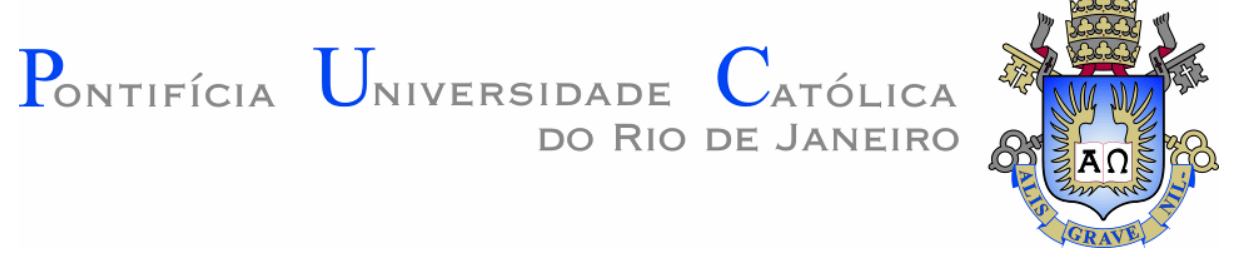

Claudio Marcio Pinheiro Martins

Quando YHWH silencia: A dinâmica entre o profeta e a palavra no livro de Amós. Análise exegética de Am 8,11-12 e sua relação com Am 7,10-17.

Dissertação apresentada ao programa de Pósgraduação em Teologia da PUC-Rio como requisito parcial para obtenção do título de mestre em Teologia Bíblica.

Orientadora: Prof ${ }^{\mathrm{a}}$. Maria de Lourdes Correa Lima

Rio de Janeiro Agosto de 2015 


\section{Quando YHWH silencia: A dinâmica entre o profeta e a palavra no livro de Amós. Análise exegética de Am 8,11-12 e sua relação com Am 7,10-17.}

Dissertação apresentada como requisito parcial para obtenção do grau de Mestre pelo Programa de PósGraduação em Teologia do Departamento de Teologia do Centro de Teologia e Ciências Humanas da PUC-Rio. Aprovada pela Comissão Examinadora abaixo assinada.

Prof ${ }^{a}$. Maria de Lourdes Correa Lima Orientadora Departamento de Teologia - PUC-Rio

Prof. Leonardo Agostoni Fernandes Departamento de Teologia - PUC-Rio

Prof ${ }^{a}$. Teresa Cristina dos Santos Akil de Oliveira Faculdade Batista do Rio de Janeiro

Profa. Denise Berruezo Portinari

Coordenadora Setorial de Pós-Graduação e Pesquisa do Centro de Teologia e Ciências Humanas - PUC-Rio

Rio de Janeiro, 24 de agosto de 2015. 
Todos os direitos reservados. É proibida a reprodução total ou parcial do trabalho sem a autorização da universidade, do autor e do orientador.

\section{Claudio Marcio Pinheiro Martins}

Graduou-se em Teologia pela Faculdade Unida de Vitória - ES em 2011. Atua no ensino teológico em instituições como o Centro Universitário Internacional - UNINTER, a Faculdade Evangélica das Assembléias de Deus - FAECAD e no Eteacher Group (Israel). Leciona Hebraico Bíblico, Exegese, e Teologia Bíblica, dentre outras disciplinas relacionadas às Escrituras Sagradas. Possui certificação e experiência em EAD. Suas pesquisas estão concentradas na Bíblia Hebraica.

Ficha Catalográfica

Martins, Claudio Marcio Pinheiro

Quando YHWH silencia : a dinâmica entre o profeta e a palavra no livro de Amós : análise exegética de Am 8,11-12 e sua relação com Am 7,10-17 / Claudio Marcio Pinheiro Martins ; orientador: Maria de Lourdes Correa Lima. 2015

107 f. : il. ; $30 \mathrm{~cm}$

Dissertação (mestrado) - Pontifícia Universidade Católica do Rio de Janeiro, Departamento de Teologia, 2015.

Inclui bibliografia.

1. Teologia - Teses. 2. Exegese do Antigo Testamento. 3. Profetismo. 4. Livro de Amós. 5. Profetas. 6. Palavra de YHWH. I. Lima, Maria de Lourdes Correa. II. Pontifícia Universidade Católica do Rio de Janeiro. Departamento de Teologia. III. Título. 
Dedico este trabalho à minha esposa Ana Lúcia e aos meus filhos Sarah e Ysrael. 


\section{Agradecimentos}

Em primeiro lugar, agradeço ao meu Senhor Jesus Cristo, autor e consumador da fé, em quem estão escondidos os tesouros da sabedoria e do conhecimento. Agradeço pela graça a mim concedida de iniciar e concluir a jornada do mestrado.

A minha amada esposa Ana Lúcia e aos meus filhos amados, Sarah e Ysrael pela paciência, amor, intercessão e compreensão em função da minha ausência em tantos momentos devido à dedicação aos estudos.

Aos meus pais Milton e Eunice por todo o amor e incentivo.

A Prof ${ }^{a}$. Dr ${ }^{a}$. Maria de Lourdes Correa Lima pela preciosa atenção e orientação, sem as quais este trabalho não seria possível. Agradeço por compartilhar comigo uma parte de tão vasto conhecimento que me servirão por toda a minha caminhada na exegese.

À PUC-Rio e aos professores do Departamento de Teologia, especialmente ao Prof. Dr. Leonardo Agostini Fernandes pelo apoio e incentivo.

Ao Programa de Pós-graduação em Teologia, representado pelo Prof. Dr. Abimar. Ao CAPES, pela concessão da bolsa de estudo, possibilitando a realização deste trabalho.

Aos funcionários do Departamento de Teologia pela atenção e serviço.

Aos meus amigos Davi, Rodrigo e Fábio, colegas de turma no propedêutico e no mestrado, que nosso Deus vos abençoe em vossa caminhada na exegese.

Ao padre Fábio Siqueira pelo acolhida e acesso ao seu acervo particular.

Ao Juan e a Roberta pelo apoio e incentivo, bem como pela ajuda com o francês. Aos amigos pastores Márcio e Francine, bem como a todo o corpo diaconal e membresia do Ministério Rei Jesus pelas intercessões. 


\section{Resumo}

Martins, Claudio Marcio Pinheiro; Lima, Maria de Lourdes Correa (Orientador). Quando YHWH silencia: a dinâmica entre o profeta e a palavra no livro de Amós. Análise exegética de Am 8,11-12 e sua relação com Am 7,10-17. Rio de Janeiro, 2015. 107 p. Dissertação de Mestrado Departamento de Teologia, Pontifícia Universidade Católica do Rio de Janeiro.

O presente trabalho estuda a relação entre o silêncio de YHWH, anunciado em Am 8,11-12 e que é manifestado pela retirada da palavra profética por meio da metáfora do envio da fome, com a rejeição desta mesma palavra pela nação, representada por Amasias, o líder da religião de Israel, tal como é relatado em Am 7,10-17. Esta pesquisa dá especial atenção à função mediadora do profeta, sua inesperada e irresistível vocação, seu senso de missão e sua identificação com a palavra de YHWH. A presença dos profetas é favor divino e sinal de que YHWH quer comunicar-se com o seu povo; o povo, por sua vez, precisa ouvir as palavras de YHWH. A rejeição da palavra de YHWH mediada pelos profetas implica, segundo o livro de Amós, em severo juízo que culminará no fim da nação. O fím do povo começou com o silêncio divino.

\section{Palavras-chave}

Exegese do Antigo Testamento; Profetismo; Livro de Amós; Profetas; Palavra de YHWH. 


\section{Abstract}

Martins, Claudio Marcio Pinheiro; Lima, Maria de Lourdes Correa (Advisor). When YHWH get silence: the dinamic between the prophet and the word in Amos's book. Exegetical analysis of Am 8,11-12 and his relation to Am 7,10-17. Rio de Janeiro, 2015. 107 p. MSc. Dissertation - Departamento de Teologia, Pontifícia Universidade Católica do Rio de Janeiro.

The present work studies the relation between the silence of YHWH, announced in Am 8,11-12 that is expressed by the withdrawal of the prophetic word through the hungry send metaphor, with this word's rejection by the nation, represented by Amasias, leather of Israel's religion, as related in Am 7,10-17. This search gives a special attention to the prophet's mediating function, his unexpected and irresistible vocation, his sense of mission and identification with the YHWH's word. The prophets' presence is a divine favor and a signal that YHWH wants to communicate Himself with His people; the people need to hear the YHWH's words. The YHWH word's rejection through the prophet implies, according Amos's book, in a severe judgment that will culminate in the end of the nation. The end of the people started with the divine silence.

\section{Keywords}

Exegesis of the Old Testament; Prophetism; Book of Amos; Prophets; YHWH's Word. 


\section{Sumário}

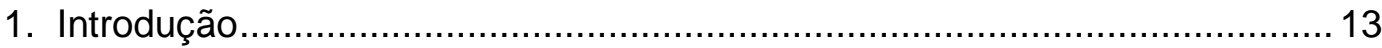

2. Am 8,11-12 em seu contexto literário .................................................... 15

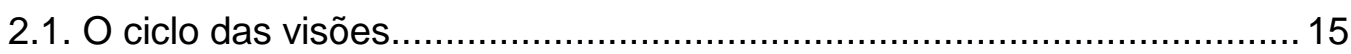

2.1.1. As cinco visões ........................................................... 15

2.1.2. Outros textos presentes no ciclo das visões.......................... 19

2.2. Am 8,11-12 no contexto imediato de Am 8,9-14 ...................................21

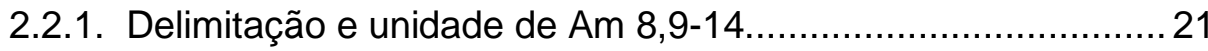

2.2.2. Organização de Am 8,9-14 ............................................... 23

2.3. Tradução e Crítica Textual de Am 8,11-12 …...................................... 25

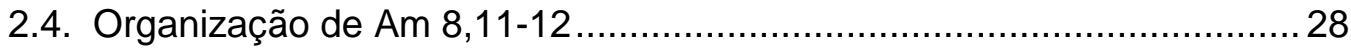

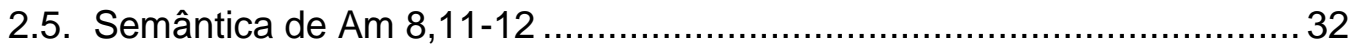

2.5.1. Introdução temporal ........................................................ 32

2.5.2. YHWH anuncia o envio da fome ............................................ 33

2.5.2.1. O anuncio propriamente dito ............................................ 33

2.5.2.2. Explicação negativa da fome ........................................... 35

2.5.2.3. Explicação positiva da fome ................................................ 36

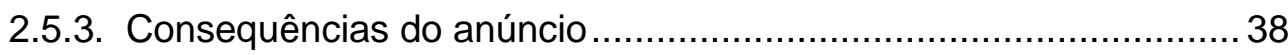

2.5.3.1. O movimento dos homens a partir da ação de YHWH........... 38

2.5.3.2. A finalidade do movimento ................................................. 39

2.5.3.3. O resultado do movimento ............................................... 40

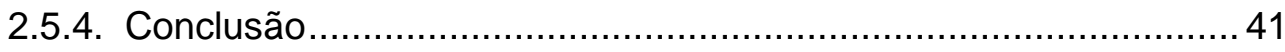




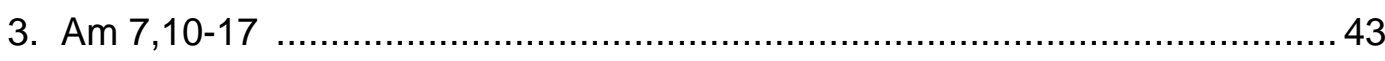

3.1. O contexto imediato.................................................................. 43

3.2. Tradução e Crítica Textual ................................................................. 44

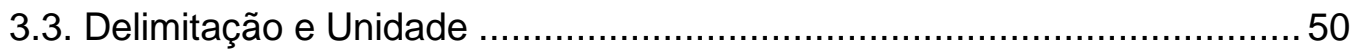

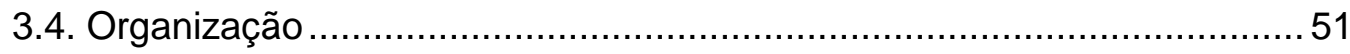

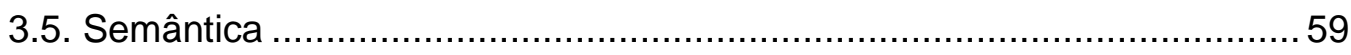

3.5.1. Palavras de Amasias a Jeroboão............................................. 59

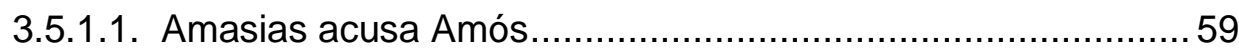

3.5.1.2. Amasias cita as palavras de Amós a Jeroboão .......................61

3.5.2. O confronto entre Amasias e Amós.............................................. 63

3.5.2.1. Amasias fala a Amós .....................................................63

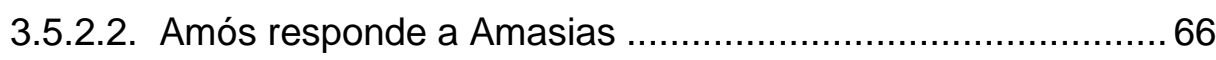

3.5.3. Amós profetiza contra Amasias................................................ 74

3.5.3.1. A justificativa para a punição de Amasias ............................ 74

3.5.3.2. O oráculo contra Amasias ............................................. 75

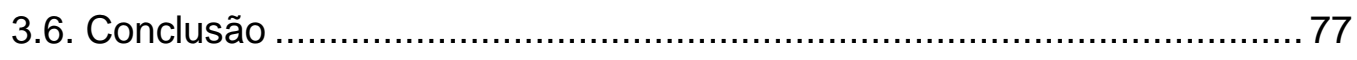

4. Am 8,11-12 e Am 7,10-17: Relações quanto ao profetismo e à palavra ........80 80

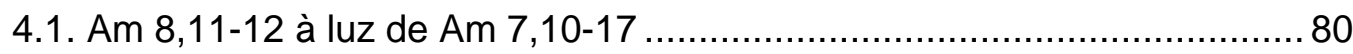

4.1.1. Am 7,10-17 e sua redação .................................................... 80

4.1.2. Am 8,11-12 e sua redação ................................................ 87

4.1.3. Am 8,11-12 e Am 7,10-17: cronologia relativa .......................... 89

4.2. A função profética e a palavra ....................................................... 91

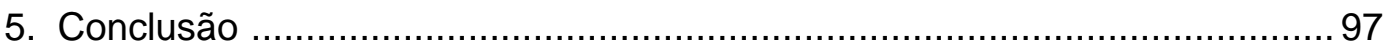

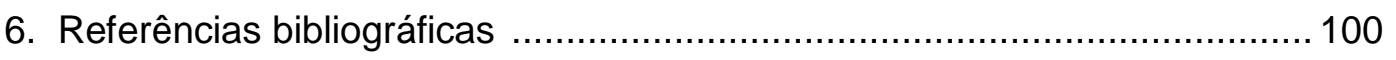




\section{Lista de siglas e abreviações}

Os nomes dos livros da Escritura Sagrada que constam deste trabalho são abreviados de acordo com as abreviaturas utilizadas na Bíblia de Jerusalém.

a.C. antes de Cristo

AT Antigo Testamento

ATeo Atualidade Teologica

BH Bíblia Hebraica

BHQ Biblia Hebraica Quinta

$\mathrm{BHQ}^{\mathrm{App}} \quad$ Biblia Hebraica Quinta. Aparato crítico

BHS Biblia Hebraica Stuttgartensia

c., cc. Capítulo(s)

Cf. Conferir

CTAT Critique Textuelle de L'Ancien Testament

DB Dicionário Bíblico

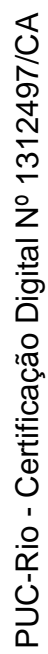

DBHP Dicionário Bíblico Hebraico-Português

DITAT Dicionário Internacional de Teologia do Antigo Testamento

DTMAT Diccionario Teologico Manual del Antiguo Testamento

ed. $\quad$ Editor(es)

f. Feminino

GELS A Greek-English Lexicon of the Septuagint

GHATIS Greek-Hebrew/Aramic two-way Index to the Sepruagint

GK Gesenius' Hebrew Grammar

Gn Gênesis

JSOT Journal for the Study of the Old Testament.

L Códice Lenigradense

NDITEAT Novo Dicionário de Teologia e Exegese do Antigo Testamento

org. Organizador(es)

p. página

pp. páginas

sg. $\quad$ Singular

TDOT Theological Dictionary of the Old Testament

TLOT Theological Lexicon of the Old Testament

TM Texto Massorético

v. / vv. Versículo(s)

vol. Volume 


\section{Lista de Tabelas}

$\mathrm{N}^{\mathrm{o}}$ Título

1 Progressão das visões e as atitudes do profeta e de YHWH 19

2 Localização das expressões הִּנּה יָמִים בָּאִים em Amós 24

3 Estrutura quiástica de Am 8,9-14 baseada nas fórmulas de introdução 26

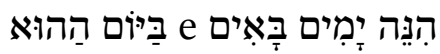

4 Estrutura quiástica de Am 8,11c-f 30

5 Estrutura de Am 8,11-12 32

6 Ocorrências da raiz שלח no hifil no contexto da BH 35

7 Comparação entre a estrutura sintática de Os 5,6 e Am 8,12 42

8 Oráculo de juízo individual em Am 7,16-17 e seus elementos 57 constitutivos

9 Estrutura de Am 7,10-17 59

10 Quadro comparativo de Am 7,15 e 2Sm 7,8 72

11 Quadro comparativo entre a palavra de YHWH em Am 7,15 e a 74 palavra de Amasias em Am 7,12

12 Quadro comparativo entre Am 7,10-17 e 1Rs 13,1-10 84

13 Vocabulário comum a Am 7,10-17 e 1Rs 13,1-10 85

14 Textos da BH que em que ocorrem a raiz גלה junto a expressão מַעל 86

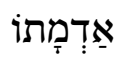

15 Quadro comparativo das semelhanças entre Am 7,16 e Jr 11,21 87

16 Quadro comparativo das semelhanças entre Am 7,17 e 87 Jr 11,21

17 Vocabulário comum a Am 8,11-12 e Am 7,10-17 91

18 Relação entre vocábulos de Am 8,11-12 e Am 7,10-17 92

19 Relação de versículos do livro de Amós com a ocorrência da raiz נבא 93 


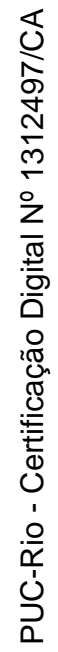

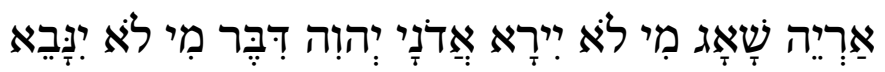
Amós 3:8 


\section{1 \\ Introdução}

O tema do profetismo recebe destaque no livro de Amós, especialmente no que concerne à sua relação com a palavra de YHWH. A importância do profetismo no livro pode ser verificada pela referência que alguns textos, além daqueles que serão analisados neste trabalho, fazem a este tema: Am 2,11-12 e Am 3,7-8. O primeiro texto, Am 2,11-12, é um oráculo no qual YHWH diz aos israelitas que ele próprio vocaciona os seus profetas, no entanto, a nação os rejeita ordenando que não profetizem. Já em Am 3,7-8 é dito que YHWH revela as suas intenções aos profetas e, através do dito proverbial do leão que ruge e traz temor aos que o ouvem, assim o profeta profetiza ao ouvir YHWH falar.

O texto de Am 7,10-17 desenvolve o tema do profetismo em forma narrativa, mostrando o confronto entre o profeta Amós e o sacerdote de Betel, Amasias, que proíbe Amós de profetizar em Betel. Já o tex to de Am 8,11-12 traz o tema da extinção palavra de YHWH.

Esta dissertação tem o propósito de verificar uma possível relação entre Am 8,11-12 e Am 7,10-17. A hipótese de trabalho é que Am 7,10-17 e Am 8,11-12 estão vinculados em uma relação de causa e efeito, respectivamente. Estes dois textos tratam diretamente da questão da palavra, possuindo vocabulário em comum.

Não serão considerados neste estudo os textos de Am 2,11-12 e Am 3,7-8, porque apesar de utilizarem a raiz נבא, não tratam diretamente da palavra, que compõe o foco deste estudo. Além disso, tais textos agregam outros temas que exigiriam uma ampliação da delimitação da pesquisa, como, por exemplo, o nazireado presente em Am 2,11-12.

Para responder a questão central deste trabalho, primeiro será analisado o texto de Am 8,11-12, porque este texto encontra-se entre os oráculos de juízo que explicam o fim da nação, e com isso mostra a que conduziu o ministério do profeta, podendo ser visto, portanto, sob certo aspecto, como uma das chaves interpretativas das ameaças feitas nos capítulos anteriores, particularmente quando entra em jogo o tema da palavra. Então, no capítulo 2, através de uma abordagem sincrônica, será 
estudado Am 8,11-12 em seu contexto literário, pela verificação dos textos que estão no seu entorno, a qual parte do livro pertence, qual é o seu contexto imediato e como relaciona-se com ele. Tal estudo é fundamental para uma compreensão mais profunda do significado do texto.

Após o estudo de Am 8,11-12, a pesquisa deter-se-á no estudo de Am 7,1017. O foco de leitura se concentrará naqueles aspectos que são relevantes para a compreensão da dinâmica da relação entre o profeta e a palavra. Então, em primeiro lugar, o texto será considerado em seu contexto imediato, que lhe oferece dados significativos para compreensão de seu sentido. Em seguida estudar-se-á a narrativa de Am 7,10-17 pondo em relevo o tema da palavra profética, do profeta, sua vocação e missão.

Como ponto de chegada desta pesquisa, na primeira parte do capítulo 4, procurar-se-á estudar o texto de Am 8,11-12 em relação a Am 7,10-17 a fim de verificar qual texto é precedente e se há uma dependência literária entre eles. Tal estudo é necessário para que se possa, com mais propriedade, estabelecer uma relação entre as duas passagens. Para este fim proceder-se-á ao estudo diacrônico pela análise redacional de cada um destes textos com o propósito de estabelecer sua cronologia relativa. Por fim na segunda parte do capítulo 4 será feita uma reflexão sobre as relações mais significativas entre a função do profeta e a palavra.

Assim, uma vez aplicada a metodologia acima descrita, espera-se compreender a relação entre o silêncio divino anunciado em Am 8,11-12 com a rejeição da palavra profética narrada em Am 7,10-17. 


\section{Amos 8,11-12 em seu contexto literário}

\section{1. \\ O ciclo das visões}

\subsection{1.}

\section{As cinco visões}

Am 8,11-12 está contido na terceira parte do livro de Amós, chamada de ciclo das visões, que compreende cinco visões e outros textos diversos. O ciclo das visões se inicia em Am 7,1 e seu término varia de acordo com a compreensão dos autores, que apontam o final da seção em Am 9,61 ou em Am 9,10².

A primeira visão está em Am 7,1-3, a segunda em Am 7,4-6, a terceira em Am 7,7-9, a quarta em Am 8,1-3 e por fim, a quinta em Am 9,1-4. Por razões formais, estilísticas e contextuais, as visões podem ser divididas em três unidades: a primeira unidade formada pelo par da primeira e segunda visão; a segunda unidade formada pelo par da terceira e pela quarta visão; e a quinta visão como sendo a terceira unidade ${ }^{3}$.

A primeira unidade ou primeiro par de visões (Am 7,1-3 e Am 7,4-6)

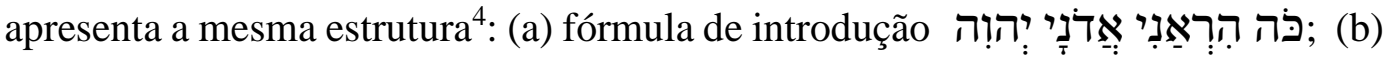
a descrição da visão; (c) intercessão do profeta; (d) YHWH mostra-se compassivo, declarando o seu perdão através da expressão לא תִת:ּיֶה.

Além da estrutura, destacam-se outros pontos em comum: (a) as duas primeiras visões também revelam o juízo de YHWH por meio dos seus agentes sejam gafanhotos (cf. Am 7,1-2) seja o fogo (cf. Am 7,4-5); (b) devido à clareza da

\footnotetext{
${ }^{1}$ Cf. ZENGER, E., “O livro de Amós”, In: Introdução ao Antigo Testamento, pp. 481, 485-486; ANDERSEN, F, I.; FREEDMAN, D, N., Amos: A New Translation With Notes and Commentary, pp. $65,71-72$.

${ }^{2}$ Cf. SMITH, G. V., Comentário do Antigo Testamento: Amós, pp. 377-383.; HUBBARD, D, A., Joel e Amós: Introdução e Comentário p.134.; ALONSO SCHÖKEL, L., Profetas, Vol.2, pp.987988; MCCOMISKEY, T. E., The Minor Prophets: An Exegetical and Expository Commentary. Vol.1: Hosea, Joel and Amos, p. 482.

${ }^{3}$ Cf. PAUL, S. M., Amos: A Commentary on the Book of Amos, p. 222.

${ }^{4}$ Cf. SMITH, G. V., Comentário do Antigo Testamento: Amós, p. 319.
} 
mensagem, dispensam qualquer explicação da visão por parte de YHWH; (c) ambas as visões iniciam-se com partícula de interjeição mais verbo no particípio; (d) possuem a raiz אכל אכרל designando a devastação que a terra haveria de sofrer; (e)

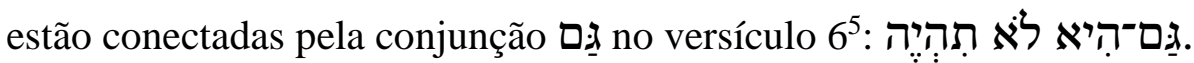

No segundo par (Am 7,7-9 e Am 8,1-3) as visões possuem estrutura semelhante $^{6}$ : (a) fórmula de introdução, contudo abreviada em Am 7,7; (b) descrição da visão; (c) YHWH questiona o profeta; (d) o profeta responde de forma sucinta; (e) oráculo explicando a visão. Neste par de visões não há mais intercessão, o juízo será irrevogável. Se no primeiro par as visões eram claras em seus significados, mostrando o juízo através da ação de gafanhotos na vegetação e do fogo sobre o solo, agora o juízo é mostrado por meio de símbolos estáticos e por isso YHWH explica a visão ao profeta. Logo, a estrutura deste segundo par difere da estrutura do primeiro par, justificando, assim, a distinção das visões em pares.

A terceira visão traz a causa do juízo através do símbolo do prumo ${ }^{7}$, que parece representar o padrão divino da justiça estabelecido pela relação entre YHWH e seu povo, mostrando que a vida política, social e religiosa de Israel estava fora do padrão de $\mathrm{YHWH}^{8}$. O oráculo que explica a visão (cf. Am 7,9) anuncia juízo sobre os santuários de Israel e sobre a casa de Jeroboão, isto é, sobre a liderança religiosa e política.

A quarta visão faz conexão com a visão precedente por meio da expressão ל לא-אוֹסִיף עוֹד עַבוֹר לו também à narrativa de Am 7,10-17 pelo tema do cativeiro de Israel presente no final do v.17 e em Am 8,2, onde é anunciado o fim ${ }^{9}$. Enquanto a terceira visão forneceu o motivo para a falta do perdão divino (Israel fora de prumo) e estabeleceu a liderança religiosa e política como alvos do julgamento, a quarta visão é a consequência da iniquidade, e o alvo é o fim de toda a nação.

\footnotetext{
5 Cf. PAUL, S. M., Amos: A Commentary on the Book of Amos, p. 224

${ }^{6}$ Cf. SMITH, G. V., Comentário do Antigo Testamento: Amós, p. 330.

${ }^{7}$ Cf. ALONSO SCHÖKEL, L., Dicionário Bíblico Hebraico-Português, p. 68. A visão parece mostrar um construtor inspecionando o muro com um prumo feito de metal. Mas de acordo com Konwel esta interpretação tradicional não é inquestionável, sendo objeto de discussão entre os estudiosos. O vocábulo אנֵ ד ocorre apenas quatro vezes na $\mathrm{BH}$, todas na terceira visão do livro de Amós (duas vezes em Am 7,7 e duas vezes em Am 7,8). Parece ter sido um empréstimo lexical do acadiano, cujo significado seria estanho ou chumbo. Cf. KONWEL, A. H., אָנז NDITEAT, p. 449.

${ }^{8}$ Cf. HUBBARD, D.A., Joel e Amós: Introdução e Comentário, p. 235-236.

${ }^{9}$ Cf. BULKeLEY, T., “Amos 7,1-8,3: Cohesion and Generic Dissonance”, In: ZAW, vol. 121, nº 4, pp. 523-524.
} 
Na quarta visão YHWH mostra ao profeta um cesto de frutos maduros ou frutos de verão ${ }^{10}$ : כְִּלוּב קָּ. No diálogo com o profeta, YHWH anuncia que chegou o fim para Israel, קֵקץ . Neste jogo de palavras sonoramente semelhantes, קָקץ, pode-se perceber a estreita relação entre a quarta visão e o destino terrível da nação, que será condenada irreversivelmente ao fim, pois a nação, retratada como fruto maduro, está pronta para o juízo. O oráculo do versículo 3 explica a visão, ao anunciar que os cânticos do palácio serão gemidos e que serão numerosos os cadáveres. O tema do lamento já surgira em Am 5,16-17 e reaparece em 8,8 e 10; e o tema de cadáveres amontoados já aparecera em Am 6,9-10.

A quinta visão (Am 9,1-4) encerra o ciclo das visões e é a concretização das visões anteriores, mormente a terceira e a quarta. Se nas visões precedentes a destruição do templo e o fim da nação foram anunciados, é na quinta visão que tudo é consumado e ninguém poderá escapar ${ }^{11}$. Esta última visão difere das demais em alguns aspectos $^{12}$ : (a) Não há a fórmula de introdução que caracterizou as demais, onde YHWH faz o profeta ver; (b) nenhum símbolo; (c) não há diálogo mas um comando para a devastação começar.

Percebe-se, pois, que há uma progressão ao longo das visões, onde à medida que as visões ocorrem há o aumento gradual do alcance do juízo divino, a diminuição das palavras do profeta até chegar ao silêncio e a disposição de YHWH para perdoar termina, comandando por fim o juízo ${ }^{13}$.

A tabela abaixo relaciona o alcance do juízo divino, a atitude de Amós e a atitude de YHWH à medida que as visões progridem:

\footnotetext{
${ }^{10}$ Cf. ALONSO SCHÖKEL, L., Dicionário Bíblico Hebraico-Português, p.580.

${ }^{11}$ Cf. SMITH, G. V., Comentário do Antigo Testamento: Amós, p. 378.

${ }^{12}$ Cf. PAUL, S. M., Amos: A Commentary on the Book of Amos, p. 273.

${ }^{13}$ Cf. PAUL, S. M., Amos: A Commentary on the Book of Amos, p. 222. Também cf. LIMA, M.L.C., “O juízo para Israel / Judá nos livros proféticos”. In: ATeo, Ano XII, fasc. 30 (2008), p. 323.
} 


\begin{tabular}{|c|c|c|c|}
\hline & $\begin{array}{l}\text { Descrição } \\
\text { da visão }\end{array}$ & Atitude do profeta & $\begin{array}{c}\text { Atitude de } \\
\text { YHWH }\end{array}$ \\
\hline $\begin{array}{c}1^{\mathrm{a}} \text { Visão } \\
\text { (Am 7,1-3) }\end{array}$ & $\begin{array}{l}\text { Gafanhotos } \\
\text { devoram a } \\
\text { vegetação }\end{array}$ & Profeta intercede & YHWH perdoa \\
\hline $\begin{array}{c}2^{\mathrm{a}} \text { Visão } \\
\text { (Am 7,4-6) }\end{array}$ & $\begin{array}{l}\text { Fogo devora o } \\
\text { solo e as fontes } \\
\text { subterrâneas de } \\
\quad \text { água }\end{array}$ & Profeta intercede & YHWH perdoa \\
\hline $\begin{array}{c}3^{\mathrm{a}} \text { Visão } \\
(\text { Am 7,7-9) }\end{array}$ & $\begin{array}{l}\text { O prumo no } \\
\text { muro }\end{array}$ & $\begin{array}{c}\text { Profeta responde a } \\
\text { pergunta de } \\
\text { YHWH com } \\
\text { poucas palavras }\end{array}$ & $\begin{array}{l}\text { YHWH não } \\
\text { perdoa mais }\end{array}$ \\
\hline $\begin{array}{c}4^{\mathrm{a}} \text { Visão } \\
(\text { Am 8,1-3) }\end{array}$ & $\begin{array}{l}\text { O cesto de frutos } \\
\text { maduros }\end{array}$ & $\begin{array}{c}\text { O profeta responde } \\
\text { a pergunta de } \\
\text { YHWH com } \\
\text { poucas palavras }\end{array}$ & $\begin{array}{l}\text { YHWH não } \\
\text { perdoa mais }\end{array}$ \\
\hline $\begin{array}{c}5^{\mathrm{a}} \text { Visão } \\
\text { (Am 9,1-4) }\end{array}$ & $\begin{array}{c}\text { O santuário } \\
\text { desmorona e o } \\
\text { povo é morto }\end{array}$ & O profeta silencia & $\begin{array}{c}\text { YHWH } \\
\text { comanda a } \\
\text { destruição }\end{array}$ \\
\hline
\end{tabular}

Tabela 1

Relação entre a progressão das visões e as atitudes do profeta e de YHWH 


\subsection{2. \\ Outros textos presentes no ciclo das visões}

No ciclo das visões estão entremeados outros textos: uma narrativa (Am 7,10$17)^{14}$, um conjunto de oráculos (Am 8,4-8;8,9-14 $\left.{ }^{15} ; 9,7-10 ; 9,11-15\right)$ e uma doxologia (Am 9,5-6).

a) Os oráculos de Am 8,4-8

Am 8,4-8 é constituído por dois oráculos breves, que acusam a nação (cf. vv.4-6), e sentenciam-na (cf. vv.7-8).

Am 8,4-6 apresenta algumas razões pelas quais Israel será condenado, demostrando assim que YHWH não é arbitrário e sim justo. Nestes motivos consta a opressão dos pobres, que tanto repete acusações anteriores quanto traz novidade. A repetição fica por conta da exploração dos pobres (cf. Am 2,6-8), que desprovidos de tudo, eram condenados a serem vendidos a fim de pagar suas dívidas, tornandose escravos dos seus credores ${ }^{16}$. Isto acontecia também com aqueles pobres que não tinham dívidas, mas que mediante o suborno dos juízes também eram condenados à escravidão ${ }^{17}$. O que há de novo é a acusação de que os israelitas estavam impacientes nos feriados religiosos, desejosos de que terminassem logo, a fim de voltarem às suas práticas comerciais desonestas e injustas e ao uso da balança fraudulenta ${ }^{18}$.

Em Am 8,7 YHWH afirma solenemente que não esquecerá que seu povo é culpado destas práticas perversas. Já em Am 8,8 é utilizado um recurso frequente no livro: a pergunta retórica (cf. Am 2,11; 3,3-8; 5,18-20; 5,25; 6,2.13; 9,7). Esta pergunta (que exige uma resposta afirmativa) tem como finalidade levar o receptor da mensagem à compreensão de que a nação é indesculpável e por isso a terra, que é o cenário daquelas referidas iniquidades, vai tremer. $\mathrm{O}$ tema do terremoto, que

\footnotetext{
${ }^{14}$ A narrativa de Am 7,10-17 será estudada no capítulo 3 desta dissertação.

${ }^{15}$ Por ser o texto do presente estudo, Am 8,9-14 será tratado à parte no ítem 2.2.1.

${ }^{16}$ Cf. SMITH, G.V., Comentário do Antigo Testamento: Amós, p.129.

${ }^{17}$ Cf. HUBBARD, D.A., Joel e Amós: Introdução e Comentário, pp. 159-160.

${ }^{18}$ Cf. HUBBARD, D.A., Joel e Amós: Introdução e Comentário, p. 247. De acordo com Hubbard, a fraude consistia em diminuir a medida do trigo, o efa, possivelmente com um forro colocado na cesta e aumentando o siclo, de modo a requerer maior volume de ouro ou prata para equilibrar a balança.
} 
dá a ideia da magnitude do juízo, aparece já na introdução do livro (cf. Am 1,1) e em outas passagens (cf. Am 2,13; 3,14-15; 9,1.5).

b) A doxologia de Am 9,5-6

Após a quinta visão encontra-se a terceira ${ }^{19}$ doxologia presente no livro de Amós e que se encontra em Am 9,5-6. Este hino doxológico exalta o poder criador e destruidor de $\mathrm{YHWH}^{20}$ pois ele é soberano sobre o seu universo e não deixa dúvida a respeito de que ele próprio executará o juízo, pois tem competência para fazê-lo ${ }^{21}$.

c) Oráculo de Am 9,7-10

Am 9,7-10 é o último oráculo de juízo presente no livro de Amós. Aqui a falsa segurança do povo é confrontada por duas perguntas retóricas (cf. Am 9,7), e a razão é que Israel imaginava que, por ter sido libertado do Egito no passado (cf Am 2,10; 3,1-2), estaria ileso de qualquer juízo (cf. Am 9,10). YHWH mostra que também conduziu o êxodo dos filisteus e dos arameus (cf. Am 9,7) e que seu povo é como os etíopes (cf. Am 9,7). A posição de povo de YHWH não deveria trazer certeza de impunidade, mas antes, de responsabilidade. Israel ignorou os preceitos éticos estabelecidos para sua relação com YHWH e desprezou a justiça, sendo assim chamado por YHWH de reino pecador que seria destruído (cf. Am 9,8). O juízo é retratado pela metáfora da peneira no v.9, e pela declaração de que os pecadores dentre o povo morrerão pela espada no v.10.

\footnotetext{
${ }^{19}$ A primeira doxologia do livro encontra-se em Am 4,13 e a segunda em Am 5,8-9.

${ }^{20}$ Cf. SMITH, G.V., Comentário do Antigo Testamento: Amós, p.379.

${ }^{21}$ Cf. HUBB ARD, D.A., Joel e Amós: Introdução e Comentário, p.255.
} 
d) Oráculo salvífico final: Am 9,11-15

O livro de Amós tem como última parte um oráculo de salvação (Am 9,11$15)^{22}$. Este oráculo, ao contrário de todo o restante do livro, suscita no receptor da mensagem uma grande esperança quanto ao futuro da nação, pois contém promessas de restauração da dinastia davídica ${ }^{23}$ (cf. Am 9,11), de grande fecundidade da terra (Am 9,13), de mudança da sorte de nação de Israel (cf. Am 9,14) e que jamais serão arrancados da terra (cf. Am 9,15).

\section{2.}

\section{Am 8,11-12 no contexto imediato de Am 8,9-14}

\subsection{1. Delimitação e unidade de Am 8,9-14}

A seção de Am 8,9-14 é precedida por duas outras seções dentro do capítulo 8. O relato da quarta visão situa-se em Am 8,1-3, onde no final do v.3 consta uma petuhá indicando início de uma seção nova no v.4. A abertura de uma nova seção no v.4 é verificada também pela mudança de gênero de relato de visão para oráculo profético, onde os acusados são convidados a ouvir a palavra por meio do imperativo שִׁמְעוּ־ץאת Nos vv 4-6 é feita uma acusação contra a opressão aos pobres bem como contra a fraude comercial. Os vv.7-8 são a consequência destas transgressões, onde YHWH diz que não esquecerá tais iniquidades e ameaça fazer a terra tremer. No final do v.8 o TM acrescenta uma setumá indicando o encerramento da seção e abertura de seção nova no v.9.

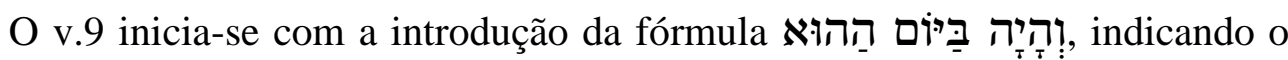
início de um novo oráculo. A unidade iniciada no v.9 estende-se até o v.14 em cujo término há presença de outra setumá. O versículo seguinte, Am 9,1, inicia o relato da quinta visão.

\footnotetext{
${ }^{22}$ É consenso entre os estudiosos que este oráculo não faz parte do ciclo das visões, sendo antes o epílogo do livro. No entanto este oráculo está relacionado no presente estudo por conectar-se ao livro como um todo, através de termos e temas que são recorrentes. Cf. LIMA, M. L. C., "Am 9,1115 e a Unidade do Livro dos Doze Profetas". In: ATeo, 14 (2003), pp. 190-195.

${ }^{23}$ Cf. ALONSO SCHÖKEL, L., Profetas, Vol.2, p. 1024.
} 
Os vv.9-14 descrevem o terror, o alcance e a severidade do juízo por vir. Os vv. 9 e 10 anunciam um eclipse solar que, associado ao tema do terremoto do versículo anterior, faz entender que céus e terra voltam-se contra Israel. O eclipse está relacionado possivelmente ao yôm $\mathrm{YHWH}^{24}$ (cf. Am 5,18-20), através da referência ao "dia" ${ }^{25}$ que, aqui, será de trevas. O fim virá e trará calamidade, o que é demonstrado através dos contrastes festas / luto e cânticos / lamentações; e pelas expressões de profunda tristeza: pano de saco e cabeças raspadas. A dor do povo será tão grande que é comparada à dor que é sentida quando se perde um filho único. A comparação é explicada em função de que, ao perder o filho único perde-se toda a esperança de descendência e continuidade ${ }^{26}$. Estava decretado o fim para Israel. Este dia seria, de fato, um dia de luto e de amargura.

Os vv. 11 e 12 desenvolvem o tema da fome. Este tema aparece em Am 4,6 com a diferença de que em Am 4,6 é fome de alimento e em Am 8,11 é fome de ouvir as palavras de YHWH. Este juízo torna este dia ainda mais insuportável ${ }^{27}$. Recusaram a palavra de YHWH através da rejeição dos seus profetas (cf. Am 2,11$12 ; 7,10-17)$ e agora, sob juízo, buscarão a palavra que rejeitaram, mas sem jamais encontrá-la.

Os vv. 13 e 14, por fim, indicam que não há esperança de futuras gerações no reino do norte porque aqueles que deveriam estar em pleno vigor (virgens e jovens, cf. Am 5,2) haveriam de desfalecer pela $\operatorname{sede}^{28}$. O tema da idolatria é também apontado neste último versículo (v.14), através do juramento que os israelitas faziam em nome dos ídolos. O v.14 é concluído asseverando que estes que tais abominações praticam cairiam e jamais se levantariam.

Então o texto de Am 8,9-14 desenvolve o tema do fim do reino do norte, tema que foi anunciado no início (v.2) e no fim (v.14) do capítulo 8.

A unidade dos vv.9-14 confirma-se não apenas pelo desenvolvimento temático, mas também por aspectos lexicais: a) os versículos 11 e 12 estão conectados pela relação de causa e efeito, respectivamente; b) o vocábulo צָָָׁא

\footnotetext{
${ }^{24}$ Cf. HUBBARD, D.A., Joel e Amós: Introdução e Comentário, p. 246.

25 Para um aprofundamento do tema, ver: FERNANDES, L.A., O Anúncio do Dia do Senhor: significado profético e sentido teológico de Joel 2,1-11, pp.357-360.

${ }^{26}$ Cf. HUBBARD, D.A., Joel e Amós: Introdução e Comentário, p. 250.

${ }^{27}$ Cf. SMITH, G.V., Comentário do Antigo Testamento: Amós, p.371.

${ }^{28}$ Cf. HUBBARD, D.A., Joel e Amós: Introdução e Comentário, p. 252.
} 
aparece nos versículos 11 e 13; c) Os versículos 9, 11 e 13 possuem fórmula com o vocábulo יוֹים

\subsection{2.}

\section{Organização de Am 8,9-14}

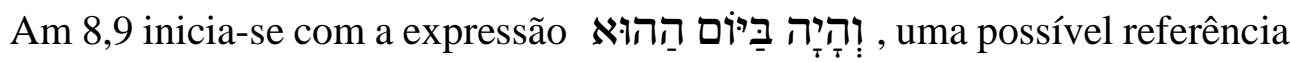
ao yôm YHWH (cf. Am 5,18). Este tema, possivelmente referido no livro em outras partes (cf. Am 2,16; 4,2) torna-se crescente no capítulo 8 (cf. vv. 3,11,13 e 14) e alcança o auge no capítulo 9 (cf. vv.11 e 13). Esta possível referência dá-se pela

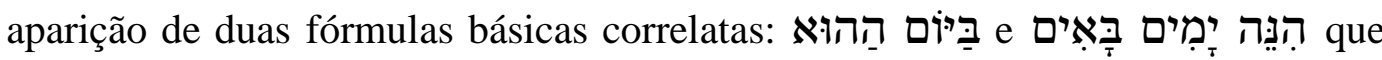
ocorrem, respectivamente, cinco e três vezes no livro, conforme a tabela a seguir:

\begin{tabular}{|c|c|c|}
\hline Seção & Versículos & Fórmula utilizada \\
\hline \multirow[b]{2}{*}{$\begin{array}{l}\text { Livro do Juízo: } \\
\text { Am } 1,1 \text { - } 4,13\end{array}$} & Am 2,16 & בַּיוּוֹם הַהוּא \\
\hline & Am 4,2 & הִנּּה זָמִים בְּאִים \\
\hline \multirow{5}{*}{$\begin{array}{c}\text { Ciclo das } \\
\text { Visões: } \\
\text { Am 7,1 - 9,10 }\end{array}$} & Am 8,3 & בַּיוֹס הַהוּא \\
\hline & Am 8,9 & וְהָיָה בַיַיוֹם הַהוּא \\
\hline & Am 8,11 & הִנּּה יָמִים בָּאִים \\
\hline & Am 8,13 & בַביוֹסט הַהוּא \\
\hline & Am 9,11 & בַּיוֹם הַהוּא \\
\hline
\end{tabular}




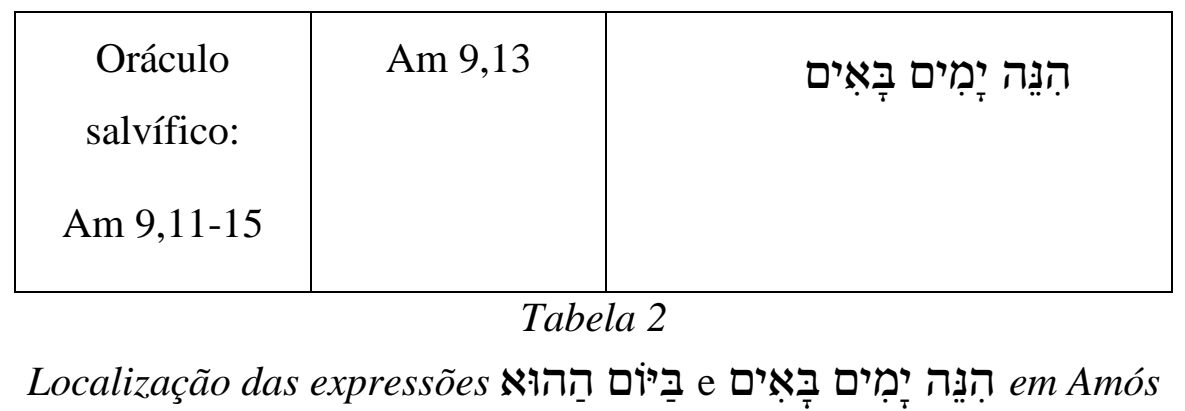

Há uma simetria na distribuição das fórmulas ${ }^{29}$, que ocorrem em pares

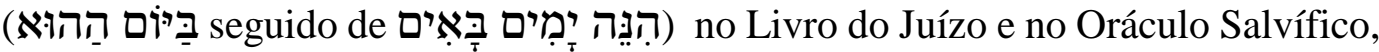
formando assim uma moldura.

Na parte central, no ciclo das visões, aparece a forma בַּיוֹס הַוּא acrescida

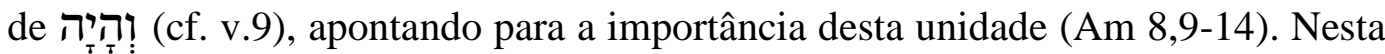
percebe-se uma moldura formada pelos vv. 9 e 13 através da forma הַיוֹס הַהוּא presente nestes versículos, tendo como centro da moldura o v.11 que tem a

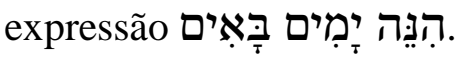

Faz-se distinção temporal aqui nesta seção do texto, entre as fórmulas

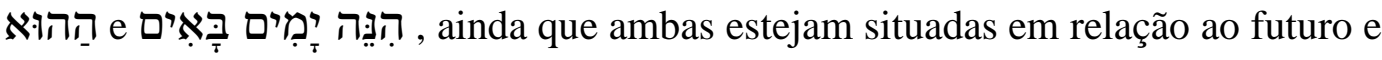
conectadas pelo mesmo tema: enquanto parece ser o tempo do juízo em

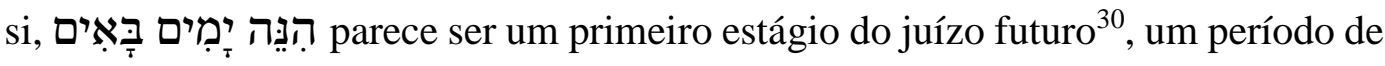
tempo $^{31}$ que integra porém antecede o dia do julgamento.

Os vv. 9 e 10 bem como 13 e 14 anunciam eventos que haveriam de atingir o cosmos bem como os israelitas em sua dimensão física: eclipse solar, lamentação, luto e desmaios pela sede. Em contrapartida os vv. 11 e 12 anunciam eventos que haveriam de atingir os israelitas em sua dimensão espiritual, pois tratam da fome e da sede de ouvir as palavras de YHWH.

A partir das observações acima, constata-se que os vv.11-12 estão no centro da unidade ${ }^{32}$ (vv.9-14) tanto pela fórmula, pelo valor temporal dos eventos anunciados, como pela natureza destes eventos. Os vv.11 e 12 evidenciam que a

\footnotetext{
${ }^{29}$ Cf. ANDERSEN, F, I.; FREEDMAN, D, N., Amos: A New Translation With Notes and Commentary, p.817.

${ }^{30}$ Cf. ANDERSEN, F, I.; FREEDMAN, D, N., Amos: A New Translation With Notes and Commentary, p.825.

${ }^{31}$ Cf. RUDOLPH, W., Kommentar zum Alten Testament: Joel, Amos, Obadja, Jona, p.266. Rudolph fala em período de tempo duradouro.

${ }^{32}$ Cf. BOVATI, P.; MEYNET, R., Le Livre du Prophète Amos, p. 331.
} 
maior necessidade dos israelitas é de natureza espiritual e que negligenciá-la resultaria no fim da nação.

A tabela a seguir traz a síntese do que foi exposto:

\begin{tabular}{|c|c|c|c|}
\hline Versículos & Fórmula & $\begin{array}{c}\text { Natureza do } \\
\text { Evento }\end{array}$ & Localização no Tempo \\
\hline vv.9-10 & וְהָיָה בַּיוֹם הַהוּא & Física & $\begin{array}{l}\text { O dia de julgamento } \\
\text { situado no futuro }\end{array}$ \\
\hline vv.11-12 & הִּנּה יְמִים בָּאִִים & Espiritual & $\begin{array}{l}\text { Dias que precedem o dia } \\
\text { de julgamento situado no } \\
\text { futuro }\end{array}$ \\
\hline vv.13-14 & בַּיוֹס הַהוּא & Física & $\begin{array}{l}\text { O dia de julgamento } \\
\text { situado no futuro }\end{array}$ \\
\hline \multirow{2}{*}{\multicolumn{4}{|c|}{ 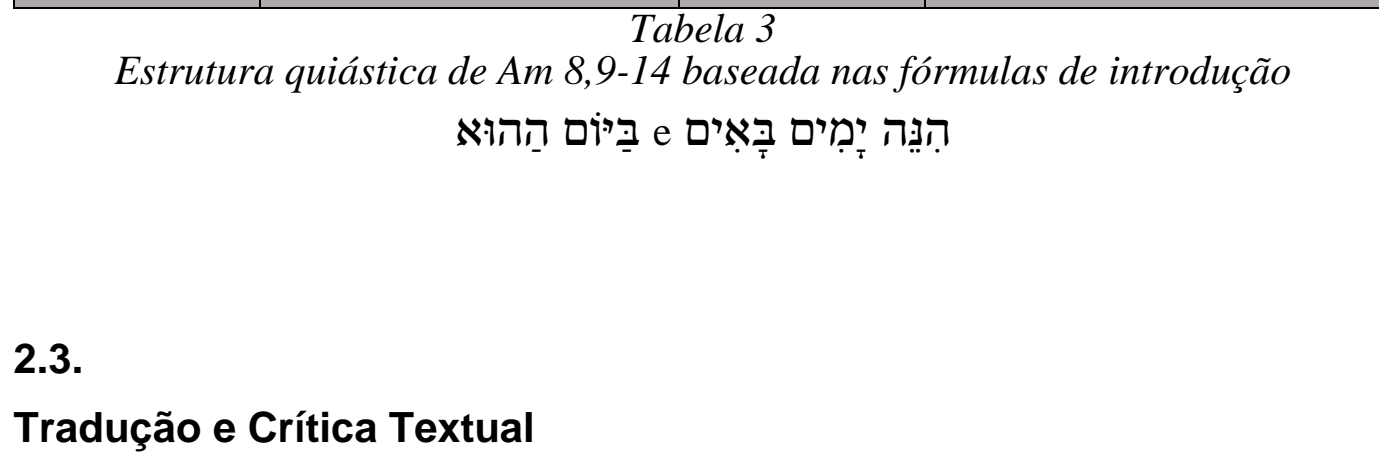 }} \\
\hline & & & \\
\hline \multicolumn{2}{|c|}{ Eis que dias estão vindo, } & $1 \mathrm{a}$ & 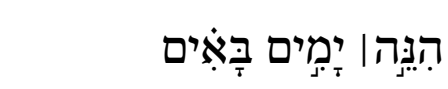 \\
\hline \multicolumn{2}{|c|}{ oráculo do Senhor YHWH: } & $\mathrm{b}$ & 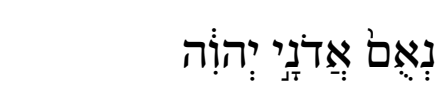 \\
\hline \multicolumn{2}{|c|}{ Enviarei fome sobre ${ }^{33}$ a terra! } & $1 \mathrm{c}$ & 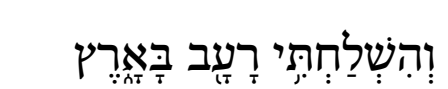 \\
\hline
\end{tabular}

${ }^{33}$ Cf. ALONSO SCHÖKEL, L., Dicionário Bíblico Hebraico Português, p.85; cf. WALTKE, B. K.; O'CONNOR, E. M., Introdução à Sintaxe do Hebraico Bíblico, p. 196. A preposição Э̦ rege o substantivo ao qual está prefixada, assumindo aqui sentido espacial. 


\begin{tabular}{|c|c|c|}
\hline Não fome de pão, & $11 d$ & 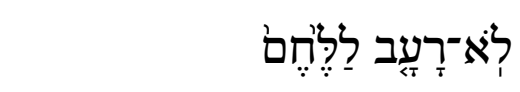 \\
\hline nem sede de água, & $11 \mathrm{e}$ & 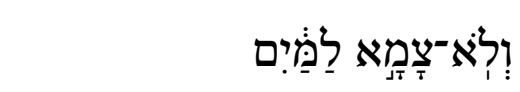 \\
\hline $\begin{array}{l}\text { mas }^{34} \text { de ouvir as palavras de } \\
\text { YHWH. }\end{array}$ & $11 \mathrm{f}$ & 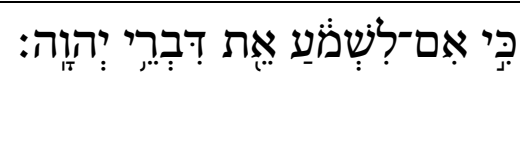 \\
\hline Vaguearão ${ }^{35}$ de mar a mar & $12 \mathrm{a}$ & 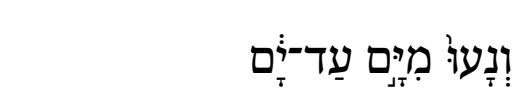 \\
\hline e do norte até o oriente. & $12 \mathrm{~b}$ & 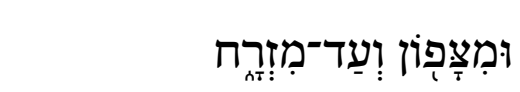 \\
\hline $\begin{array}{l}\text { Percorrerão }{ }^{36} \text { para buscar a } \\
\text { palavra de YHWH }\end{array}$ & $12 \mathrm{c}$ & 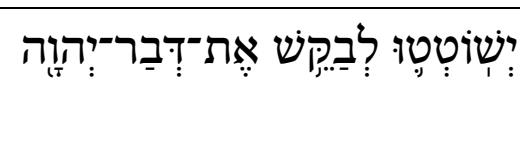 \\
\hline mas não a $\mathrm{a}^{37}$ encontrarão. & $12 \mathrm{~d}$ & וְלְא יִמְצָאוּ: \\
\hline
\end{tabular}

$\mathrm{O} \mathrm{BHQ}^{\mathrm{app}}$ aponta as seguintes variantes de leitura nos versículos abaixo:

\section{v.11}

A LXX, a Vulgata e a versão Siríaca trazem, em 11b, uma leitura distinta: "Senhor" ao invés de "Senhor YHWH"; entretanto, o nome divino composto é atestado no manuscrito 88 de Murabba'at bem como no Targum. O TM do Códice Leningradense atesta ampla ocorrência do nome divino composto no livro de

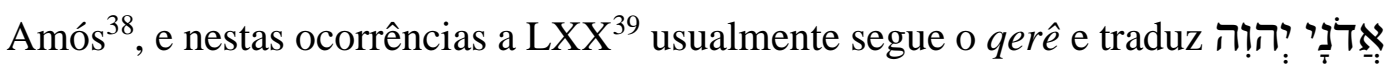

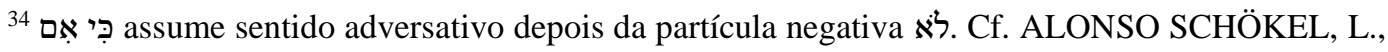
Dicionário Bíblico Hebraico Português, pp. 312-313.

${ }^{35}$ Cf. ALONSO SCHÖKEL, L., Dicionário Bíblico Hebraico Português, p.426.

${ }^{36}$ Cf. ALONSO SCHÖKEL, L., Dicionário Bíblico Hebraico Português, p.663. O verbo aqui em referência tem o sentido de percorrer ou vagar. O complemento do verbo, exigido pela língua portuguesa, está implícito no versículo anterior.

${ }^{37} \mathrm{O}$ complemento verbal é exigido pela gramática portuguesa, embora não conste do texto hebraico.

${ }^{38}$ Cf. Am 1,$8 ; 3,7 ; 3,8.11 .13 ; 4,2.5 ; 5,3 ; 6,8 ; 7,1-2.4-5 ; 7,6 ; 8,1.3 .9 .11 ; 9,5.8$.

${ }^{39}$ Quando a LXX lê "Senhor" recorda o nome divino único. O comentário do aparato crítico da BHQ informa-nos que é uma questão aberta se trata-se ou não de uma "vorlage" hebraica mais curta. Cf. Comentary of the Critical Aparatus, in BHQ, pp.78-79.
} 
por "xúplos ó Өcós", e da mesma forma faz a Vulgata ao traduzir por "Dominus Deus”. Assim sendo faz-se a opção pelo TM do Códice Leningradense.

A LXX, as recensões de Áquila a Teodocião e a Vulgata confirmam, em 11de, a presença dos substantivos צִמָא e רָָָ e De acordo com o comentário ao $\mathrm{BHQ}^{\mathrm{app} 40}$, a versão Siríaca e o Targum vocalizaram צמא e como particípios e não como substantivos, no entanto confirmam a presença destas consoantes. $\mathrm{O}$ manuscrito 88 de Murabba'at traz uma leitura "indeterminada". O TM do Códice Leningradense está amplamente atestado pelos testemunhos acima citados.

Não consta de BHQ ${ }^{\text {app }}$ mas pode-se observar que a LXX acrescentou "fome" em 11e: "mas fome de ouvir a palavra de YHWH", ao invés de "mas de ouvir a palavra de YHWH", conforme o texto do Códice Leningradense. A Vulgata lê conforme o TM. Provavelmente a LXX acrescentou "fome" para que o complemento do verbo "enviar" ficasse explícito. O TM do Códice Leningradense, de leitura mais breve, é preferível.

A LXX, a Vulgata, a versão Siríaca e o Targum, em 11f, lêem Tִִּ (no singular) ao invés de דְִִּר? (plural). O Códice Leningradense, no entanto, é apoiado por alguns manuscritos do Targum. A expressão singular "palavra de YHWH” é muito mais frequente na BH que a expressão plural "palavras de YHWH". Barthélemy prefere não assimilá-la à expressão no singular que aparece no versículo seguinte, embora lhe pareça provável que tenha havido, em 11f, uma ditografia do yod (dbrY YHWH) ocasionando, assim, o plural ${ }^{41}$. Também Andersen-Freedman ${ }^{42}$ optam pelo plural porque, segundo eles, é mais fácil uma alteração partindo do plural (menos comum) para o singular (mais comum) que ao contrário. Assim opta-se pelo texto do Códice Leningradense.

v.12

A LXX traz $̋ \delta \alpha \tau \alpha$, “água”, ao invés de $\theta \alpha \dot{\lambda} \alpha \sigma \sigma \sigma \alpha$, "mar”, em 12a, porque

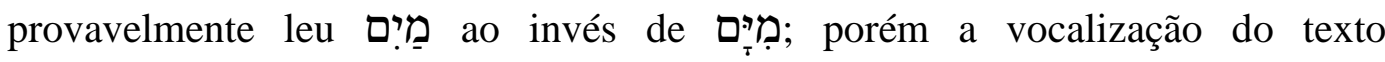

${ }^{40}$ Cf. Comentary of the Critical Aparatus, in BHQ, p. 87.

${ }^{41}$ Cf. BARTHÉLEMY, D., Critique Textuelle de l'Ancien Testament, vol. 3, p.686-687; Também cf. BOVATI, P; MEYNET, R., Le Livre du Prophète Amos, p. 328.

${ }^{42}$ Cf. ANDERSEN, F, I.; FREEDMAN, D,N., Amos: A New Translation With Notes and Commentary, p.823. Para Andersen e Freedman as variantes podem surgir, neste caso, tanto por ditografia (dbrY YHWH) como por hapografia (dbr YHWH). 
Leningradense é apoiada pela Vulgata, pela Siríaca e pelo Targum. O Targum fez uma leitura distinta da segunda ocorrência de "mar", no entanto o manuscrito 88 de Murabba'at bem como a LXX, a Vulgata e a versão Siríaca confirmam o TM. Também aqui faz-se a opção pelo Códice Leningradense.

\section{4 .}

\section{Organização do Texto}

O texto se inicia com o uso da interjeição הנֵ que junto ao verbo no particípio

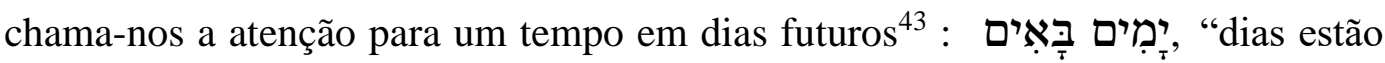
vindo". Esta expressão põe em relevo o aspecto temporal da ação. O evento que será anunciado tem a garantia do seu cumprimento por ser palavra de $\mathrm{YHWH}$, o

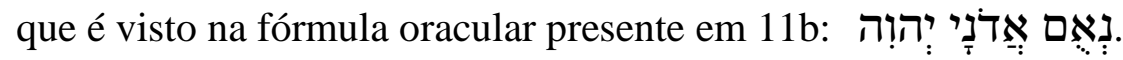

Após as fórmulas iniciais (11ab) é feito o anúncio do evento a ocorrer no

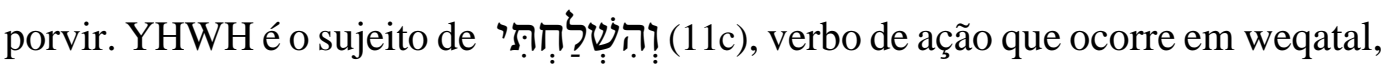
forma que faz referência às ações orientadas temporalmente para o futuro e que se admite como certas ${ }^{44}$. Os complementos do verbo são רָָָּ (ocorre duas vezes: 11c

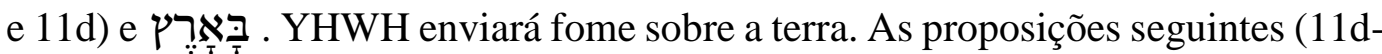
11f) explicam o tipo de fome que será enviada por YHWH. As duas primeiras (11d11e) explicam de forma negativa, mostrando que tipo de fome não será, por meio da partícula negativa לא que ocorre duas vezes: 11d e 11e. Não será fome de pão nem sede de água, o que amplia o sentido da fome; assim este bicólon é caracterizado por um paralelismo sintético ou complementar ${ }^{45}$. A preposição ? ocorre quatro vezes: Em 11d e 11e está prefixada aos substantivos לִ? "מִ , "pão" e מַיִם "água”. Estes substantivos pertencem ao gênero dos alimentos, mostrando assim que não se trata de fome natural. Já as outras duas ocorrências da referida preposição estão em $11 \mathrm{f}$ e $12 \mathrm{c}$, e ali está prefixada a verbos no infinitivo construto: לִבַקְּש של (12d). Estes verbos, aqui, possuem sentido semelhante e têm o mesmo complemento: a palavra de YHWH.

\footnotetext{
${ }^{43}$ Cf. MCCOMISKEY, T. E., The Minor Prophets - Vol 1: Hosea, Joel, and Amos, p.392-393.

${ }^{44}$ Cf. DEL BARCO, F. X., Profecía y Sintaxis. El uso de las formas verbales em los Profetas Menores Preexílicos, pp. 250.

${ }^{45}$ Cf. ANDERSEN, F. I.; FREEDMAN, D. N., Amos: A New Translation With Notes and Commentary, p.702.
} 
A proposição seguinte (11f) é iniciada pela formulação אִ̣ que aqui assume sentido adversativo em relação às duas proposições anteriores e explica, de

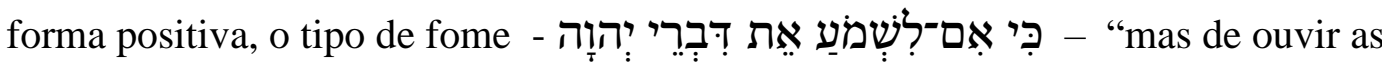
palavras de YHWH”. Assim no v.11, após as palavras iniciais que servem de introdução (11a-b), segue-se uma moldura formada pela ação de YHWH (11c) e da explicação positiva da ação de YHWH (11f). A explicação negativa acerca do que YHWH envia encontra-se no centro (11d-e). Os segmentos $11 \mathrm{c}-\mathrm{f}$ formam um quiasmo, e o v.11 pode ser considerado como construído de forma concêntrica. ${ }^{46}$

A tabela a seguir mostra o que foi dito acima:

\begin{tabular}{|c|c|c|}
\hline $11 \mathrm{c}$ & 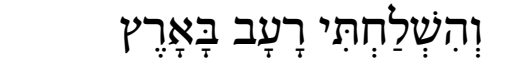 & A \\
\hline $11 d$ & 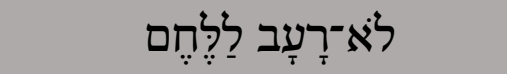 & B \\
\hline $11 \mathrm{e}$ & 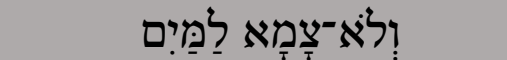 & $B^{\prime}$ \\
\hline $11 \mathrm{f}$ & 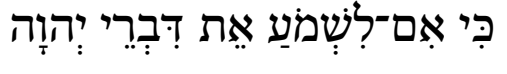 & $A^{\prime}$ \\
\hline
\end{tabular}

Tabela 4

Estrutura quiástica de Am 8,11c-f

A partir do v.12 há uma mudança no sujeito dos verbos. A ação de YHWH em 11c provoca a reação dos homens em 12a. Os homens que estão "sobre a terra" reagirão à fome enviada por YHWH: "vaguearão" - וֹזָעעו - verbo também em weqatal como em 11c. Este é um verbo cujo movimento é assim descrito em nosso

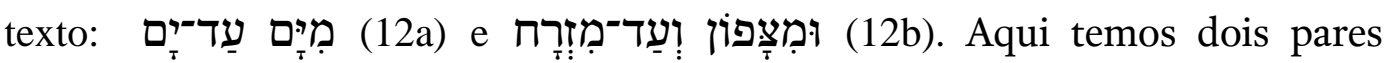
iniciados pela preposição מִין, conectados interiormente pela preposição עַד e entre si pela conjunção aditiva ?! Pode-se perceber um paralelismo sintético entre os referidos pares. A ênfase está no movimento espacial geográfico de um lugar até outro: de leste a oeste (12a) e do norte ao oriente (12b).

O propósito deste movimento é descrito por um outro verbo integrante do mesmo campo semântico da raiz שישוֹטְטוּר ${ }^{47}$ : נוע raiz verbo agora em yiqtol.

\footnotetext{
${ }^{46}$ Cf. BOVATI, P.; MEYNET, R., Le Livre du Prophète Amos, p. 239-240.

47 Em relação à posição deste verbo na segmentação, os massoretas do Códice Leningradense puseram o acento disjuntivo átnah na palavra precedente מִזָָרח, deslocando assim o verbo para o
} 
A finalidade de todo este esforço é especificada em 12c através do verbo no

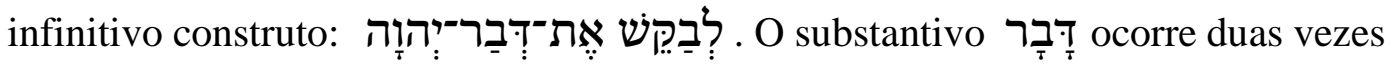
de forma explícita no texto em estudo e uma vez de forma implícita. A primeira em 11f, no plural construto, a segunda em 12c no singular construto e a terceira em 12d por ser o complemento implícito do verbo.

O v.12 encerra-se mostrando o resultado de todo aquele movimento: a busca da palavra de YHWH mostrar-se-á infrutífera - ולְא יִמְצָאו. Assim o v.12 inicia

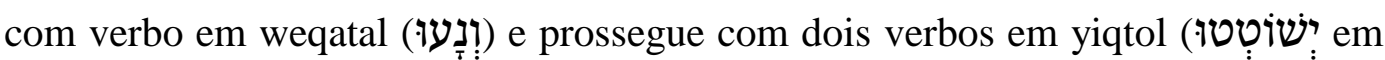
12c e יִמְבָאָו. em 12d) que preservam a orientação futura do weqatal no discurso preditivo $^{48}$. É possível que haja um jogo de palavras ${ }^{49}$ sonoramente semelhantes

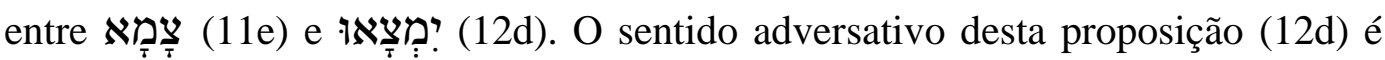

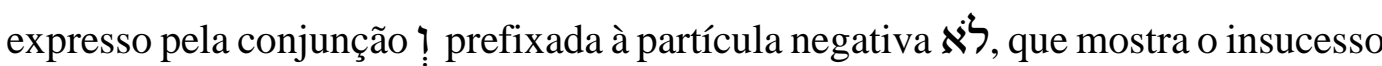
de toda aquela ação empreendida em busca da palavra de YHWH. Há um paralelismo antitético (buscar / não encontrar) entre 12c-d.

Assim, o movimento de $12 \mathrm{a}-\mathrm{c}$ não chega a sua meta em $12 \mathrm{~d}$ pois o resultado é negativo. Pelo exposto, os vv.11-12 estruturam-se da seguinte forma:

I - Introdução temporal - (11a-b)

II - YHWH anuncia o envio da fome (11c-f)

II.1 - O anúncio propriamente dito (11c)

II.2 - Explicação negativa do tipo de fome: não é fome natural (11d-e)

II.3 - Explicação positiva do tipo de fome: é fome espiritual (11f)

início do segmento seguinte (12c). Este arranjo, conforme observaram ANDERSEN e FRIEDMAN, quebra a conexão com o verbo anterior (por serem verbos do mesmo campo semântico). Porém,

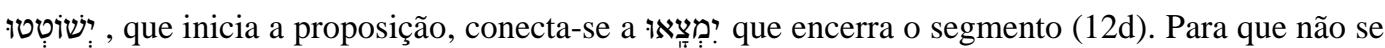
perdesse nenhuma destas possibilidades, ANDERSEN e FRIEDMAN, seguindo C. H. GORDON,

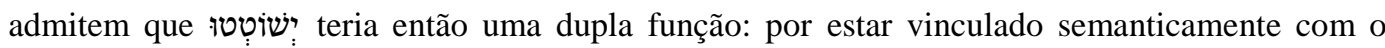
primeiro verbo encerraria o bicólon anterior, e, simultaneamente, inicia o bicólon seguinte, que encerra também com um verbo, estando, assim, no centro do v.12. Cf. ANDERSEN, F, I.; FREEDMAN, D. N., Amos: A New Translation With Notes and Commentary, p. 702.

${ }^{48}$ De acordo com Del Barco, a estrutura com yiqtol é uma estrutura alternativa do weqatal. No discurso preditivo, o (w)-x-yiqtol tem a mesma função do weqatal. Cf. DEL BARCO, F. X. Profecía y Sintaxis. El uso de las formas verbales em los Profetas Menores Preexílicos, pp. 251-252.

${ }^{49}$ Cf. LANDY, F., "Visions and Poetic Speech in Amos", Hebrew Annual Review, vol. 11, 1987, pp. 239-240. 
III - Consequências do anúncio da ação de YHWH (12a-d)

III.1 - O movimento dos homens a partir da ação de YHWH (12a-b)

III.2 - A finalidade do movimento: buscar a palavra de YHWH (12c)

III.2 - O Resultado negativo do movimento: não a encontrarão (12d)

A estrutura de Am 8,11-12 pode ser visualizada também pela tabela a seguir:

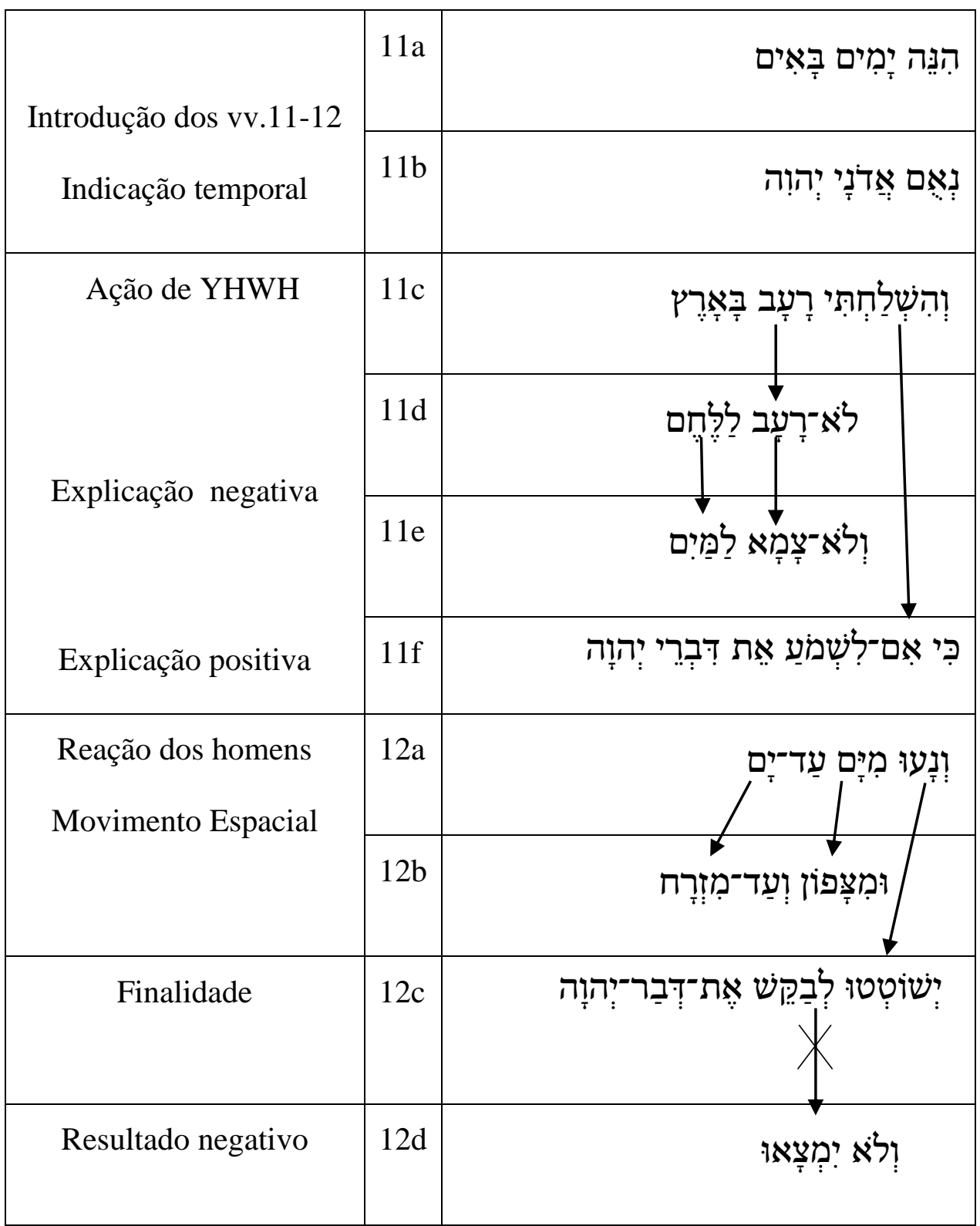

Tabela 5

Estrutura de Am 8,11-12 


\section{5 . \\ Semântica de Am 8,11-12}

\subsection{1. Introdução temporal (11a-b)}

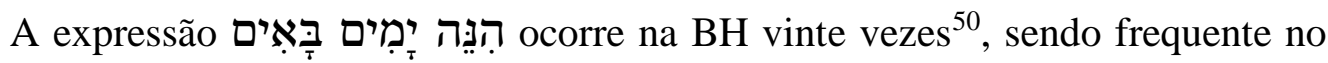
livro de Jeremias (14 vezes) ${ }^{51}$. Em Amós ocorre em Am. 4,2; 8,11; 9,13. A partícula הִּנ:ה aparece em Amós sempre com o propósito de chamar a atenção do receptor da mensagem para YHWH e sua atividade ${ }^{52}$, pois este fará algo novo ou inesperado ${ }^{53}$. A raiz בוא é a quarta mais frequente na $\mathrm{BH}$, cujo sentido primário é "ir, chegar, entrar"54. A referida raiz aqui (11a) aparece no particípio plural

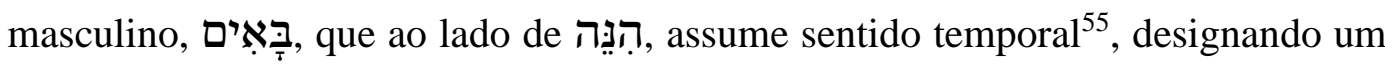
futuro que se aproxima ${ }^{56}$. יוֹ é o mais importante conceito de tempo na $\mathrm{BH}$, que pode referir-se tanto a um momento, quanto a um período de tempo ${ }^{57}$.

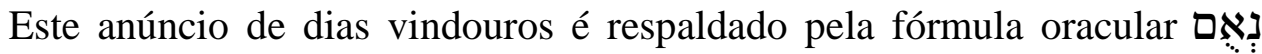

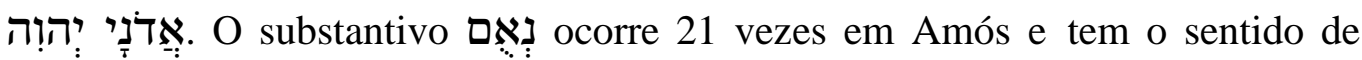
oráculo, vaticínio; é derivado da raiz נאם que significa "pronunciar oráculos, emitir vaticínios" ${ }^{\text {58 }}$.É usado exclusivamente para a voz de $\mathrm{YHWH}^{59}$ chamando a atenção do receptor da mensagem para a autoridade de quem fala e para o conteúdo da fala. O nome divino composto é frequente no livro de Amós, mas a expressão

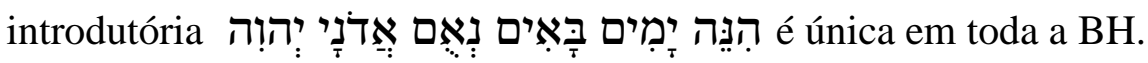

Assim, já na introdução do texto, anuncia-se um período futuro no qual haverá a ação de YHWH que resultará na mudança da sorte do povo ${ }^{60}$. Este tempo por vir será, possivelmente, de julgamento sobre a nação.

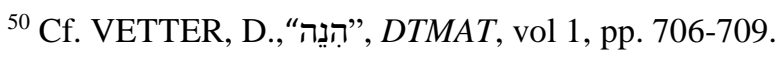

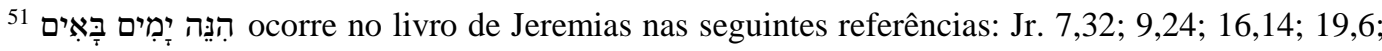
23,5.7; 30,3; 31,27.31; 33,14; 48,12; 49,2; 51,47.52.

${ }^{52}$ WOLFF, H. W., Joel and Amos: A Commentary on the Books of the Prophets Joel and Amos, p.142.

${ }^{53}$ Cf. HARMAN, A., "Partículas", NDITEAT, vol.4, p. 1028.

${ }^{54}$ Cf. MARTENS, E, A., "אilב", DITAT, p.155-157.

${ }^{55}$ Cf. ALONSO SCHÖKEL, L., Dicionário Bíblico Hebraico-Português, p.91.

${ }^{56}$ Cf. PAUL, S.M., A Commentary On The Book of Amos, p.130.

${ }^{57}$ Cf. COPPES, L. J., "יוֹים", DITAT, p.604-606.

${ }^{58}$ Cf. ALONSO SCHÖKEL, L., Dicionário Bíblico Hebraico-Português, p.414.

${ }^{59}$ Cf. COPPES, L. J., "נㅠ", DITAT, pp. 900-901.

${ }^{60}$ Cf. MCCOMISKEY, T.E., Hosea, Joel and Amos, in: The Minor Prophets: An Exegetical and Expository Commentary, vol. 1, p.393.
} 


\subsection{2.}

\section{YHWH anuncia o envio da fome}

\subsubsection{1.}

\section{$\mathrm{O}$ anúncio propriamente dito}

Após a introdução, entra-se no conteúdo do oráculo, em 11c, através de

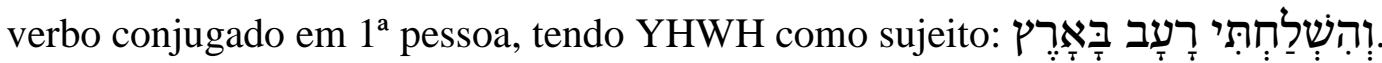
A raiz שלח tem ampla ocorrência na BH. Na diversidade de usos desta raiz há em comum o fato de que o objeto do verbo é afastado do sujeito; se o objeto é afastado completamente a raiz assume o sentido de enviar, ou mandar pessoas ou coisas para alguém ou para algum lugar ${ }^{61}$. Se o objeto está unido ao sujeito, a raiz assume o sentido de estender. Há ainda outros sentidos como soltar, lançar, disseminar, divorciar e acender.

No texto em estudo a raiz está no hifil weqatal, com o sentido de enviar. As cinco ocorrências da raiz שלח no hifil no contexto da BH apresentam a mesma sintaxe e a mesma semântica ${ }^{62}$ : o sujeito é YHWH, o objeto é um flagelo, praga ou desastre $^{63}$. O contexto é sempre de juízo. Portanto trata-se aqui de um oráculo cuja mensagem é desfavorável à nação de Israel, e, provavelmente culminará em juízo sobre o reino do norte.

A tabela abaixo explicita o que foi dito:

\footnotetext{
${ }^{61}$ Cf. DELCOR, M.; JENNY. E; "שלח", DTMAT; p. 1142-1149.

${ }^{62}$ Cf. COLLINS, C. J., "שלח", in: NDITEAT, Vol 4; p.121; Cf. PAUL, S.M., A Commentary On The Book of Amos, p.265.

${ }^{63}$ Cf. WOLFF, H.W., Joel and Amos: A Commentary on the Books of the Prophets Joel and Amos, p.330.
} 


\begin{tabular}{|c|c|c|c|}
\hline \multicolumn{3}{|c|}{ Ocorrências da raiz של no hifil no contexto BH } \\
\hline Referência & Sujeito & Complemento de & O alvo do juízo \\
& & של & \\
\hline Ex 8,17 & YHWH & Enxame de & Egito \\
\hline Lv 26,22 & YHWH & Feras do campo & Israel \\
\hline 2 Rs 15,37 & YHWH & Rezim e Peca & Judá \\
\hline Ez 14,13 & YHWH & Fome & A terra que pecar \\
\hline Am 8,11 & YHWH & Fome & Israel \\
\hline
\end{tabular}

Tabela 6

Ocorrências da raiz שלח no hifil no contexto da BH

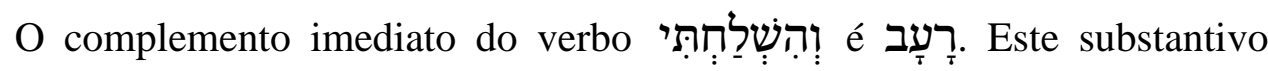
ocorre 101 vezes na BH e a maioria das suas ocorrências está no livro de Jeremias ${ }^{64}$ $(34 x)$, em Gênesis ${ }^{65}(25 x)$ e no livro de Ezequiel $^{66}(16 x)$. Há apenas duas ocorrências no livro de Amós, ambas em Am 8,11. As duas ocorrências de רָָָָ no Deuteronômio estão em Dt 28,48 e em Dt 32,24, em ambas a fome é juízo divino, resultado de não ouvir a palavra de $\mathrm{YHWH}^{67}$; a fome tem o mesmo motivo em Jeremias e em Ezequiel ${ }^{68}$. A fome quando atinge uma região forçosamente leva o

\footnotetext{
64 רָעָ ocorre em Jeremias nos seguintes versículos: Jr 5,12; 11,2; 14,12.13.15(2x).16.18; 15,2(2x); 16,$4 ; 18,21 ; 21,7.9 ; \quad 24,10 ; 27,8.13 ; 29,17.18 ; \quad 32,24.36 ; \quad 34,17 ; \quad 38,2.9 ; \quad 42,14.16 .17 .22$; $44,12(2 x) \cdot 13 \cdot 18.27 ; 52,6$.

רָעָב ocorre em Gênesis nos seguintes versículos: Gn 12,10 (2x); 26,1 (2x); 41,27.30 (2x).31.36 (2x). $50.54(2 \mathrm{x}) .55 .56(2 \mathrm{x}) .57 ; 42,5 ; 43,1 ; 45,6.11 ; 47,4.13(2 \mathrm{x}) .20$.

רָָּּב 66 ocorre em Ezequiel nos seguintes versículos: Ez 5.12.16 (2x).17; 6,11.12; 7,15(2x); 12,16; $14,13,21 ; 18,7.16 ; 34,29 ; 36,29.30$.

${ }^{67}$ Cf. MCCOMISKEY, T.E., The Minor Prophets: An Exegetical and Expository Commentary. Vol 1: Hosea, Joel and Amos, p.475. A escassez da palavra de YHWH era uma maldição decorrente da da desobediência à YHWH.

${ }^{68}$ Cf. SEIDL, T., "רָרָברבר lado de דֶּר como instrumentos de YHWH para punir o seu povo.
} 
povo assolado à migração, para buscar alimento em outros lugares: este foi o caso de Abraão (cf. Gn 12,10), de Isaac (cf. Gn 26,1), de José (cf. Gn 42,5ss), de Rute (cf. Rt 1,1) e de Eliseu (cf. 2Rs 8,1).

\subsubsection{2.}

\section{Explicação negativa do tipo de fome: não é fome natural (11d-e)}

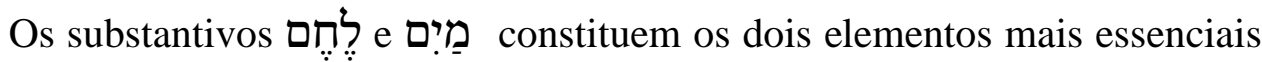
à sobrevivência física humana: pão (alimento) e água. לֶֶ ocorre mais de 470 vezes na $\mathrm{BH}$ tamanha sua importância e presença no quotidiano, principalmente dos mais pobres ${ }^{69}$.

Em Amós ocorre ainda em Am 4,6 com o sentido de alimento físico e em Am 7,12 com o sentido de subsistência. O substantivo צָז amplia mensagem, ocorrendo 17 vezes na BH e duas vezes em Amós (Am 8,11.13). צָמָא expressa a maior necessidade física do ser humano que é ingerir água, pois a falta da água é ainda mais danosa à saúde que a falta de alimento $^{70}$. Em textos como Is 5,13 e Is 65,13-14 a sede é punição vinda da parte de YHWH devido à apostasia do seu povo.

צִ צָמָא רעָב aparecem juntos em cinco versículos da BH: Dt 28,48; $2 \mathrm{Cr}$ 32,$11 ; \mathrm{Ne} 9,15 ;$ Is 5,13 e Am 8,11. Fome e sede estão relacionados com cativeiro e serviço aos inimigos em Dt 28,48 e Is 5,13. O tema da fome e da sede já aparecera em Amós, em Am 4,6-8 bem como nas duas primeiras visões (Cf. Am 7,1.4) ${ }^{71}$.

Assim, a fome e a sede que serão enviadas por YHWH não são de ordem natural $^{72}$, pois não se trata de escassez de pão e água, elementos indispensáveis à vida humana.

\footnotetext{
${ }^{69}$ Cf. DOMMERSHAUSEN, W., "לֶֶ", TDOT, vol. 7, p.521. Cf. Ex 23,25; 2Rs 6,22; Jó 22,7;

Ez 12,18.

${ }^{70}$ Cf. KELLERMANN, D., "צָמָ", TDOT, vol. 12, p. 406.

${ }^{71}$ Cf. PAUL, S.M., Amos: A Comentary on the Book of Amos, p.265.

${ }^{72}$ Cf. RUDOLPH, W., Kommentar zum Alten Testament: Joel, Amos, Obadja, Jona, p.266.
} 


\subsubsection{3.}

\section{Explicação positiva do tipo de fome: é fome espiritual (11f)}

YHWH explica, agora de forma positiva, o tipo de fome que ele enviará à

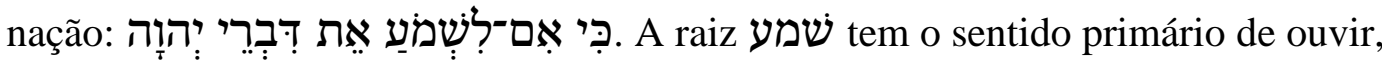
escutar $^{73}$. Ocorre mais de 1159 vezes na BH, em praticamente todos os livros ${ }^{74}$. No livro de Amós esta raiz aparece 10 vezes ${ }^{75}$ e aqui aparece no qal infinitivo construto,

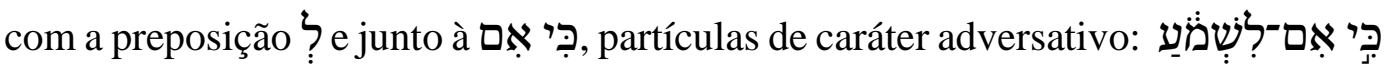
76 , "mas de ouvir".

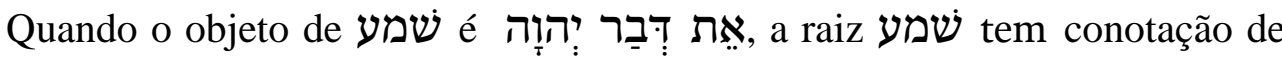
obedecer $^{77}$ (cf. 1Rs 12,24; 2Cr 11,4). YHWH comunica as suas palavras ao seu povo por intermédio dos seus profetas, resultando daí a importância em ouvir: ouvir para compreender ${ }^{78}$ e então obedecer. Já o substantivo רָדָ ocorre aproximadamente 1440 vezes na $\mathrm{BH}$ e é o décimo substantivo mais frequente nas escrituras sagradas ${ }^{79}$.

Uma expressão de grande valor teológico é termo técnico para a revelação profética ${ }^{80}$. Ocorre no singular 225 vezes $^{81}$ e no plural há 17 ocorrências, sendo que a grande parte das ocorrências de está na literatura profética, incluindo textos narrativos referentes aos profetas. é objeto direto em 52 ocorrências e, destas, a maioria (36) é objeto da raiz שמעy. Em Amós a expressão no singular aparece em Am 7,16 e Am 8,12 e no plural apenas em Am 8,11.

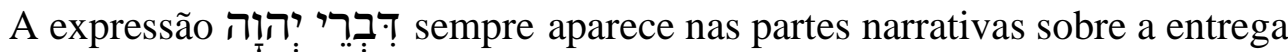
das palavras de YHWH ao povo através dos profetas, nunca aparecendo em

\footnotetext{
${ }^{73}$ Cf. ALONSO SCHÖKEL, L., Dicionário Bíblico Hebraico-Português; p.681.

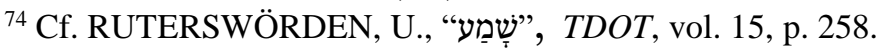

${ }^{75}$ Em Amós a raiz שמע aparece em Am 3,1.9.13; 4,1.5; 5,1.23; 7,16; 8,4.11.

${ }^{76}$ Cf. ALONSO SCHÖKEL, L., Dicionário Bíblico Hebraico-Português; p.312.

${ }^{77}$ Cf. RUTERSWÖRDEN, U., "שַָָׁ", TDOT, vol. 15, p.258.

${ }^{78}$ Cf. AITKEN, A. T., "שמע", NDITEAT, vol 4, p.174. O envolvimento da mente está implícito quando ouve-se palavras.

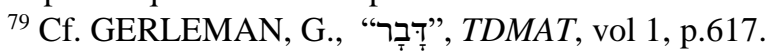

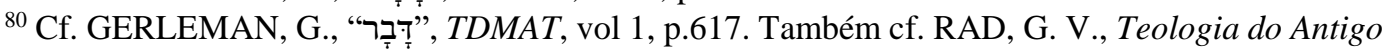
Testamento, p. 523.

${ }^{81}$ Cf. GERLEMAN, G., "דָדָָּ", TDMAT, vol 1, p. 624.
} 
pronunciamentos oraculares ${ }^{82}$. Em contraste com a forma no singular, a forma plural refere-se à forma escrita das mensagens proféticas bem como ao conteúdo do código do decálogo. A forma plural aparece na perícope do Sinai, em Ex 24,3-4 onde Moisés pronuncia as palavras de YHWH ao povo e depois as escreve. Esta relação das palavras de YHWH com o código do decálogo faz o profeta um autêntico herdeiro da tradição mosaica, cabendo-lhe atualizar as palavras de YHWH para a sua geração.

A ameaça anunciada sob a forma do envio da fome de ouvir as palavras de YHWH deve-se ao fato de que a aliança realizada no Sinai envolvia ouvir e obedecer as palavras de YHWH (cf. Ex 19,8; 24,3). A desobediência acarretaria o silêncio divino e o fim do povo (cf. Dt 32,20) pois a escassez da palavra era uma maldição decorrente da quebra da aliança ${ }^{83}$. Aqui e em outros textos na $\mathrm{BH}$ o silêncio divino é presságio da sua ira ${ }^{84}$ (cf. $1 \mathrm{Sm} 14,37 ; 28.6 .15-16$ ).

Portanto, a fome de ouvir palavras de YHWH remete a Dt 8,3, onde surge a percepção de que a vida humana tem necessidades mais profundas que não apenas alimento físico e que somente pode ser suprida com as palavras de YHWH. Sob este panorama o texto aponta para um duplo significado para a fome e para sede ${ }^{85}$ : há o aspecto físico e natural, de pão e água, mas há àquele trancendente, de natureza espiritual. A metáfora da fome aponta para a maior necessidade humana: ouvir (obedecer) as palavras de YHWH (cf. Ez. 33,30-33). A relação entre a palavra de YHWH e o seu povo é vital: Israel viveria e prolongaria sua existência na terra ${ }^{86}$ prometida através da palavra divina (cf. Dt 32,47).

82 Cf. ANDERSEN, F, I.; FREEDMAN, D, N., Amos: A New Translation With Notes and

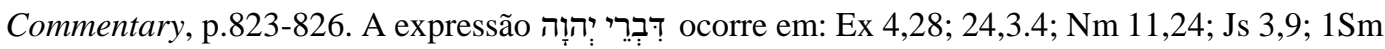
8,10; 15,1; 2Cr 11,4; Jr 36,4.6.8.11; 37,2; 43,1; Ez 11,25 e Am 8,11.

${ }^{83}$ Cf. MCCOMISKEY, T. E., The Minor Prophets: An Exegetical and Expository

Commentary. Vol 1: Hosea, Joel and Amos, p.475.

${ }^{84}$ Cf. PAUL, S. M., Amos: A Comentary on the Book of Amos, p.265.

${ }^{85}$ Cf. ANDERSEN, F. I.; FREEDMAN, D, N., Amos: A New Translation With Notes and Commentary, p. 823.

${ }^{86}$ Cf. SNYMAN, S. D., "The land as a leitmotiv in the book of Amos", pp. 536-537, in: Verbun et Ecclesia, vol. 26, n 2, 2005. 


\subsection{3.}

\section{Consequências do anúncio (12a-d)}

\subsubsection{1.}

\section{O movimento dos homens a partir da ação de YHWH (12a-b)}

O anúncio da ação de YHWH, em 11c-f, faz iniciar a movimentação, em 12a-

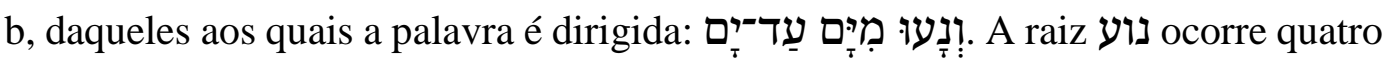
vezes no livro de Amós (cf. Am 4,8; 8,12 e 9,9 (2x)). Tem o sentido primário de um movimento repetido de um ponto a outro, para trás e para a frente; designa também movimento sem direção e instável ${ }^{87}$; se ocorre em pequena extensão assume a idéia de tremer, oscilar; se em grandes extensões, de vagar, cambalear e perambular $^{88}$. Descreve desde o balanço das folhas das árvores ao soprar do vento (cf. Is 7,2), o tremor do povo de Deus no Sinai (cf. Ex 20,18), a perambulação para encontrar água durante a seca (cf. Am 4,8), o vagar sem rumo de um vagabundo (cf. 2Sm 15,20), a vida errante de Caim (cf. Gn 4,12) até o movimento cambaleante de um bêbado ${ }^{89}$ (cf. Is 24,20). Aparece aqui no qal, com o sentido de "vaguear"90 como também Am 4,8. No contexto de Am 4,8 o povo estava buscando água, em Am 8,12 o povo busca a palavra de YHWH. Assim é descrito o movimento daqueles que, sem a palavra para guiá-los, estarão desorientados e cambaleantes ${ }^{91}$.

Ainda em 12a, texto prossegue tratando do deslocamento daqueles homens.

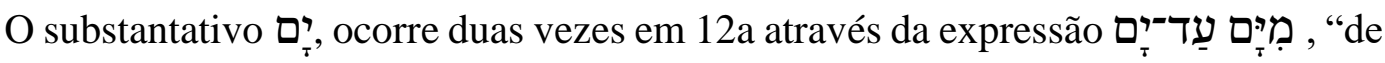
mar a mar”. Esta é uma expressão de difícil interpretação que tem dividido os estudiosos.

Basicamente as linhas interpretativas são:

(1) Para Paul, a expressão “de mar a mar" significa do Mar Mediterrâneo (ao ocidente) ao Mar Morto (ao sul), que formam junto com as expressões "do norte ao oriente" os quatro pontos cardeais, indicando os limites da Palestina. ${ }^{92}$

\footnotetext{
${ }^{87}$ Cf. WOLFF, H, W., Joel and Amos: A Commentary on the Books of the Prophets Joel and Amos p.330.

${ }^{88}$ Cf. BOWLING, A; “נוע", DITAT, p.1328.

${ }^{89}$ Cf. RINGGREN, H., "נוע", TDOT, vol. 9, p.294.

${ }^{90}$ Cf. ALONSO SCHÖKEL, L., Dicionário Bíblico Hebraico-Português, p.426.

${ }^{91}$ Cf. VAN PELT, M.V.; KAISER JR,W.C., "נוע" in NDITEAT, vol. 3, p.64-65.

${ }^{92}$ Cf. PAUL, S.M., Amos: A Comentary on the Book of Amos, p.266.
} 
(2) Para McComiskey, "de mar a mar" é o equivalente hebraico de uma expressão acadiana que significa “do mar superior ao mar inferior", ou seja, do Mar Mediterrâneo ao Golfo Pérsico, entendendo este autor que o povo terá fome das palavras de YHWH no exílio. O norte e o oriente indicam a direção de onde vêm os conquistadores (cf. Is 41,25 e Dn 11,44). Sendo assim estes seriam os limites do império assírio. ${ }^{93}$

(3) Para Wolff, "de mar a mar" sugere os confins da terra. Wolff entende que se a intenção do texto fosse indicar os limites da Palestina, o cólon seguinte não teria sentido ${ }^{94}$.

(4) Andersen e Freedman seguem Wolff, e sugerem que o norte e o oriente seriam direções míticas e lendárias, não havendo, segundo eles, nenhum significado nesta ordem ${ }^{95}$. Parece corroborar com Wolff e com Andersen e Freedman o fato de que a expressão מִיָים עַד־ים ocorrer, além de Am 8,11 apenas em mais dois versículos da $\mathrm{BH}$ : S1 72,8 e Zc 9,10, cujos contextos apontam para toda a terra.

O texto segue tratando da abrangência geográfica deste movimento através

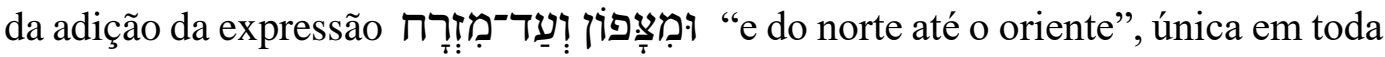
a BH. Os israelitas, privados da palavra de YHWH e portanto desorientados, vaguearão por toda parte. A palavra de YHWH, que antes estava tão disponível, bem próxima deles em sua própria terra, a ponto de não precisarem de grandes esforços para encontrá-la (cf. Dt 30,11-14) agora não lhes é mais acessível, pois foilhes retirada.

\subsubsection{2.}

\section{A finalidade do movimento: buscar a palavra de YHWH (12c)}

O texto segue em $12 \mathrm{c}$ onde encontramos a raiz שוט, que ocorre 5 vezes no polel $^{96}$ e é ocorrência única no livro de Amós. No polel tem o sentido de percorrer,

\footnotetext{
${ }^{93}$ Cf. MCCOMISKEY, T.E., The Minor Prophets: A Exegetical and Expository Comentary. Vol.1: Hosea, Joel and Amos, p.475.

${ }^{94}$ Cf. WOLFF, H, W., Joel and Amos: A Commentary on the Books of the Prophets Joel and Amos, pp.330-331.

${ }_{95}$ Cf. ANDERSEN, F, I., FREEDMAN, D. N., Amos: A New Translation With Notes and Commentary, p.826.

${ }^{96} \mathrm{~A}$ raiz aparece no polel nos seguintes versículos: 2Cr 16,9; Jr 5,1; Dn 12,4; Am 8,12 e Zc 4,10.
} 
vagar, dar voltas. O movimento expresso pela raiz שוּט não é direcionado para um lugar específico ${ }^{97}$, mas retrata o vagar desorientado de um lugar a outro.

A finalidade deste movimento desorientado é expressa pelo uso da raiz בּקט, que ocorre, na $\mathrm{BH}$, quase que exclusivamente no piel (222 vezes, e apenas 3 no pual). Aparece uma única vez no livro de Amós e tem o sentido de buscar, procurar o que se perdeu ${ }^{98}$. Exprime uma busca fervorosa e diligente pelo objeto da procura בקש tem emprego teológico, particularmente quando YHWH é o objeto da busca. Aqui a busca por YHWH está explícita na busca pela sua palavra.

\subsubsection{3.}

\section{O resultado do movimento: não encontrarão a palavra de YHWH (12d)}

Todo o movimento de busca pela palavra de YHWH tem o desfecho em 12d. A raiz מצא tem o sentido primário de encontrar. A finalidade de todo movimento בּקש e מצא empreendido em Am 8,12 é encontrar a palavra de YHWH. As raízes ocorrem juntas cerca de 35 vezes ${ }^{100}$. No texto em questão apesar de toda a busca os israelitas não logram êxito, pois não encontram mais a palavra de YHWH. A relação dinâmica de buscar e não encontrar ${ }^{101}$ é encontrada na BH cerca de 20 vezes, dentre as quais: Is 41,12 e Ez 26,21 em relação aos inimigos; em Ec 7,28 e 8,17 em relação à sabedoria; em Os 5,6 em relação à YHWH, e em Am 8,12 em relação à palavra de YHWH.

Os 5,6 e Am 8,12 possuem uma estrutura sintática similar, conforme tabela abaixo:

\footnotetext{
${ }^{97}$ WASCHKE, E. -J., "שוּט:"in TDOT, vol 14, p. 529.

${ }^{98}$ Cf. PAUL, S.M., Amos:a Comentary on the Book of Amos, p.267. Cf. GERLEMAN, G., בקי in DTMAT, p.484.

${ }^{99}$ Cf. COPPES, L.J., "בקש", DITAT, p. 210-211.

100 Cf. GERLEMAN, G., "מצא", DTMAT, p. 1256.

${ }^{101}$ Cf. SIMIAN-YOFRE, H., Amos: Nueva Versione, Introduzione e Commento, p.167-168.
} 


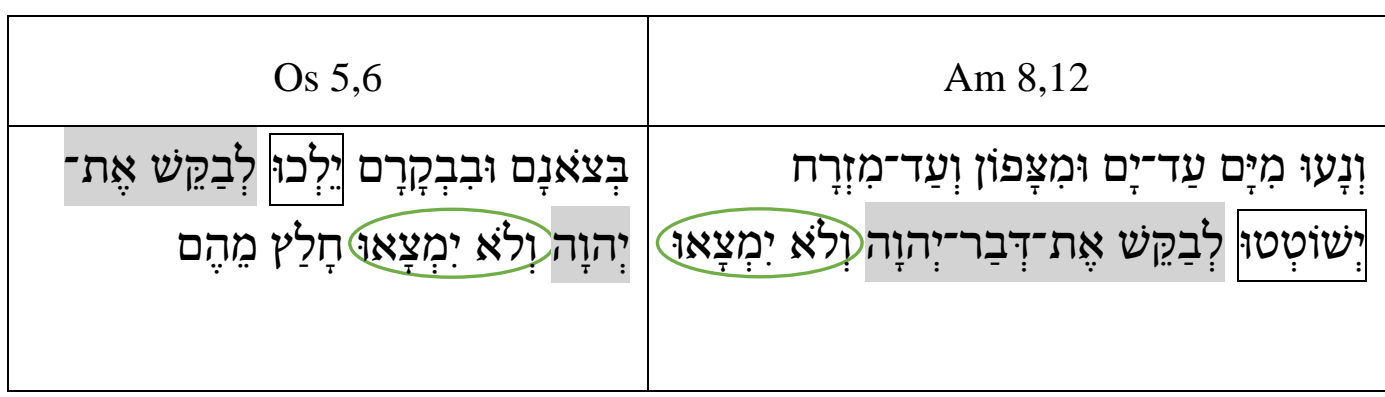

Tabela 7

Comparação entre a estrutura sintática de Os 5,6 e Am 8,12

Em ambos os textos há uma busca por YHWH e em ambos não há êxito nesta busca, pois os homens não o encontram. A razão é que, também em ambos, YHWH tomou a iniciativa de retirar-se e assim ninguém pode encontrá-lo.

Uma possível lição é que se há acesso à palavra de YHWH pela mediação dos profetas é porque YHWH quer comunicar-se e assim poderá ser encontrado. Mas se YHWH não quiser mais revelar-se e retirar a sua palavra, e então ninguém poderá encontrá-lo.

\subsection{4. \\ Conclusão}

Am 8,11-12 integra o conjunto de oráculos de Am 8,4-14 que explicam o fim da nação de Israel anunciado na quarta visão (cf. Am 8,1-3). Se nos dois primeiros pares de visão (cf. Am 7,1-3 e Am 7,4-6) YHWH perdoou o seu povo devido à intercessão do profeta (cf. Am 7,2.5). No entanto, os dois pares seguintes (cf. Am 7,7-9 e Am 8,1-3) mostram que a disposição para perdoar havia terminado.

A nação tal qual um cesto de frutos maduros estava pronta para o juízo porque fora advertida pelo profeta por causa dos seus pecados: injustiça contra os pobres ${ }^{102}$, o luxo exorbitante das elites (cf. Am 3,5; 6,4-6), o culto dissociado da vida (cf. Am 4,4-5; 5,18-27) e a falsa segurança (cf. Am 9,10). YHWH os convocou ao arrependimento (cf. Am 5,4-6; 14-15) mas o povo rejeitou a palavra de YHWH ao rejeitar os seus profetas (cf. Am 2,11-12; 7,12-13.16).

${ }^{102}$ Cf. Am 2,6-8; 3,10.12.15; 4,1; 5,11; 8,4. 
O uso de elementos como pão, água, fome e sede chama a atenção para necessidades inadiáveis do ser humano. Ao fazer a analogia entre pão e palavra o texto alerta para a importância da palavra de YHWH para a nação de Israel: assim como um ser humano pode morrer por falta de pão assim também a nação pela ausência da palavra de YHWH. O israelita deve viver pela palavra de YHWH (cf. Dt 8,3), sendo-lhe esta palavra a sua própria vida (cf. Dt 32,47). Am 8,11-12 anuncia a fome que atinge a dimensão mais profunda do ser: a alma humana, pois esta tem necessidades que estão além de pão e água, pois precisa ser nutrida e orientada pela palavra divina.

Esta procura desorientada pela palavra de YHWH levaria os israelitas aos mais longínquos lugares, de um lado a outro, mas sem nenhum resultado. Sem a palavra divina não poderiam mais retornar a YHWH.

Assim Am 8,11-12 mostra que o fim da nação começa com o silêncio de YHWH. A nação não mais ouvirá as palavras de YHWH. As palavras divinas estarão disponíveis na sua forma escrita mas não haverá mais a proclamação e atualização destas palavras. ${ }^{103}$

${ }^{103}$ Cf. ANDERSEN, F, I.; FREEDMAN, D,N., Amos: A New Translation With Notes and Commentary, pp.823-826. 


\section{Am 7,10-17}

\section{1.}

O contexto imediato

A narrativa de Am 7,10-17 interrompe a sequência das visões iniciada em Am 7,1, estando situada entre a terceira (Am 7,7-9) e a quarta visão (Am 8,1-3). A narrativa mantém coesão temática e linguística com a visão precedente ${ }^{104}$ e também

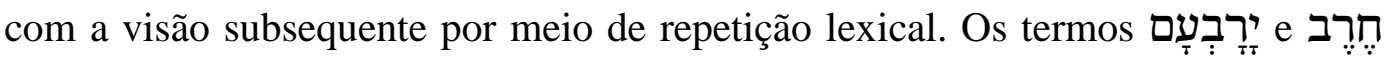

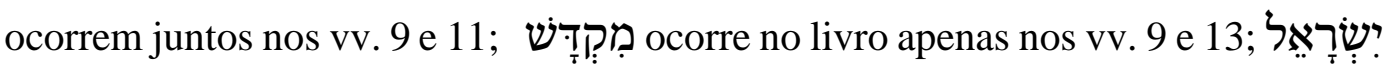

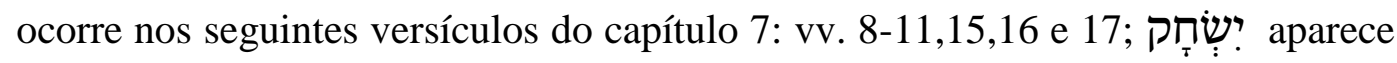
nos vv. 9 e 16; בֵּית aparece nos vv. 9, 10, 13 e 16. Já os seguintes termos e expressões ocorrem tanto na narrativa quanto na terceira e quarta visão: עָממוֹס

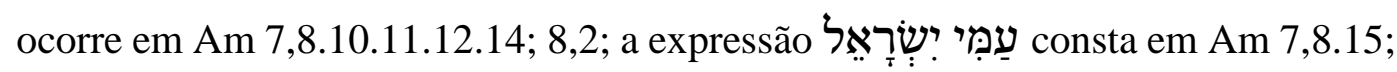
Am 8,2; e por último temos a raiz יסף mais as partículas לעוֹ e עלא formando uma expressão que repete-se em Am 7,8.13; 8,2. Portanto Am 7,10-17 mantém forte conexão linguística com o contexto imediato.

A narrativa tem um início abrupto pois interrompe uma sequência de três relatos de visões. O relato do encontro entre o profeta Amós e o sacerdote Amasias também termina abruptamente quando chega no v.17 105 , sendo sucedida imediatamente por um quarto relato de visão.

Provavelmente o propósito desta narrativa não é fornecer um relato detalhado da vida de Amós ${ }^{106}$, pois nada informa sobre as circunstâncias da sua chegada em Betel e nada diz com respeito ao seu destino após este encontro. $\mathrm{O}$ possível motivo para isto é que o foco da narrativa não está propriamente em Amós,

104 Cf. BULKELEY, T., "Amos 7,1-8,3: Cohesion and Generic Dissonance”, In: ZAW, vol. 121, n 4 , p. 526 ,

${ }^{105}$ Cf. ANDERSEN, F. I., FREEDMAN, D. N., Amos: A New Translation with Notes and Commentary, p. 763.

${ }^{106}$ Cf. JEREMIAS, J., Amos: Traduzione e Commento, p. 176. 
mas sim em Amasias e em sua postura de rejeição à palavra divina da qual Amós é portador.

A narrativa pode ser considerada como um apoftegma ${ }^{107}$, cuja finalidade é tornar compreensível o oráculo contra Amasias e contra a nação ao elucidar as circunstâncias em que o oráculo surgiu.

Portanto, Am 7,10-17 faz a junção da terceira com a quarta visão, tendo a finalidade de explicar a terceira visão e justificar a quarta: explica ${ }^{108}$ a terceira visão na medida em que mostra que a liderança de Israel estava fora de prumo porque rejeitara a palavra de YHWH e por outro lado justifica a quarta visão porque mostra o porquê do fim da nação, uma justa consequência do seu repúdio à palavra de YHWH.

\section{2.}

\section{Tradução e Crítica Textual}

\begin{tabular}{|c|c|c|}
\hline $\begin{array}{l}\text { Amasias, sacerdote de Betel, } \\
\text { mandou dizer a Jeroboão, rei de } \\
\text { Israel: }\end{array}$ & $10 \mathrm{a}$ & 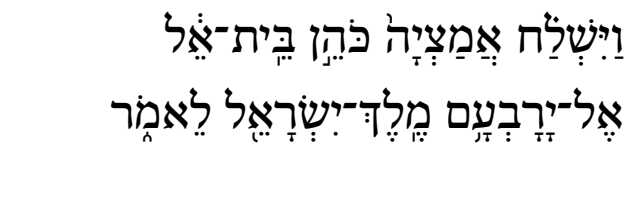 \\
\hline $\begin{array}{l}\text { "Amós conspira contra ti dentro }{ }^{109} \\
\text { da casa de Israel; }\end{array}$ & $10 \mathrm{~b}$ & 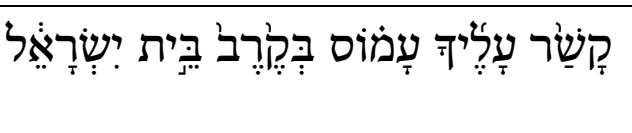 \\
\hline $\begin{array}{l}\text { A terra não pode suportar todas as } \\
\text { suas palavras. }\end{array}$ & $10 \mathrm{c}$ & 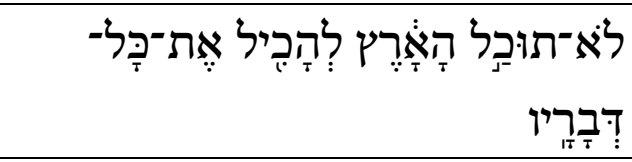 \\
\hline Pois assim diz Amós: & $11 \mathrm{a}$ & כִּי־ذה אָמֵר עָמֹוֹס \\
\hline Jeroboão morrerá pela espada & $11 \mathrm{~b}$ & 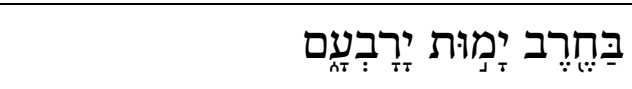 \\
\hline
\end{tabular}

${ }^{107}$ Cf. WOLFF, H, W., Joel and Amos: A Commentary on the Books of the Prophets Joel and Amos, p. 308.

${ }^{108}$ Cf. NOBLE, R. N., "Amos and Amaziah in Context: Synchronic and Diachronic Approaches to Amos 7-8”, The Catholic Biblical Quarterly, vol. 60, n 3, Jul 1998, p. 427.

109 Cf. ALONSO SCHÖKEL, L., Dicionário Bíblico Hebraico-Português, p. 591. קְרִ acrescido com a preposição ?̦ pode ser traduzido por: dentro, adentro, em meio a. 


\begin{tabular}{|c|c|c|}
\hline $\begin{array}{l}\text { e Israel certamente será deportado } \\
\text { de sua terra." }\end{array}$ & $11 \mathrm{c}$ & 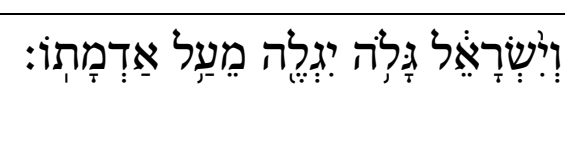 \\
\hline Então disse Amasias para Amós: & $12 \mathrm{a}$ & וַיְּאמֶר אֶמַצַיָה אֶל־עָמוֹס \\
\hline "Visionário!"10 & $12 \mathrm{~b}$ & 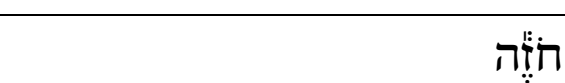 \\
\hline Vai! & $12 \mathrm{c}$ & אלקּף \\
\hline Foge ${ }^{111}$ para a terra de Judá & $12 \mathrm{~d}$ & 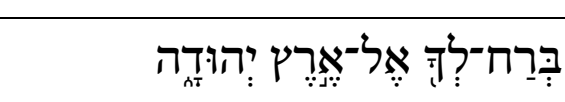 \\
\hline e lá come pão & $12 \mathrm{e}$ & 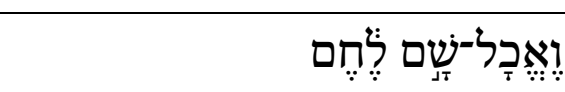 \\
\hline e lá profetiza ${ }^{112}$ & $12 \mathrm{f}$ & 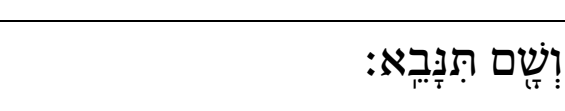 \\
\hline $\begin{array}{l}\text { Mas em Betel não continuarás }{ }^{113} \text { a } \\
\text { profetizar }\end{array}$ & $13 \mathrm{a}$ & 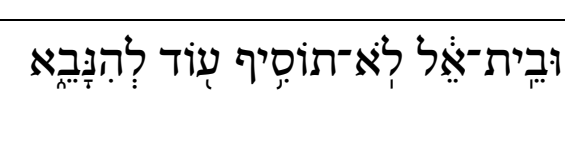 \\
\hline porque é santuário do rei & $13 b$ & 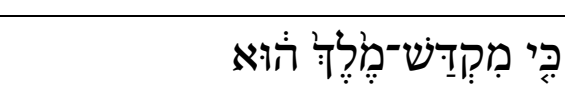 \\
\hline e templo do reino". & $13 \mathrm{c}$ & 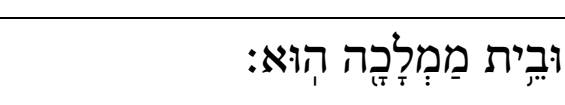 \\
\hline Amós replicou & $14 \mathrm{a}$ & 1ַיְעַַן עָמוֹס \\
\hline e disse a Amasias: & $14 \mathrm{~b}$ & 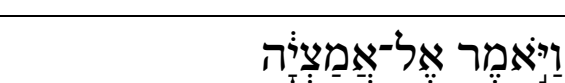 \\
\hline
\end{tabular}

\footnotetext{
${ }^{110}$ A opção de tradução "visionário" deve-se à distinção existente entre רֶֶּ e normalmente traduzido por "vidente".

111 בִּרַח : a preposição ל? aqui tem a função de dativus commodi, pois mostra para quem ou em favor de quem a ação é realizada. Particularmente neste caso a preposição ?̧ está ligada ao sufixo pronominal que também é o sujeito do verbo, assumindo assim um significado reflexivo: "foge-te". Cf. JOÜON, P.; MURAOKA, T., Gramática del Hebreo Bíblico, § 133, p. 520. Nesta tradução dispensou-se o sufixo de $2^{\mathrm{a}}$ pessoa por não fazer-se necessário na língua portuguesa.

$112 \mathrm{O}$ verbo em yiqtol foi traduzido no imperativo porque neste caso o yiqtol substituiu o verbo no imperativo. Cf. COMLEY, A. E., Gesenius' Hebrew Grammar as Edited and Enlarged by the Late E. Kautzch, § 107n. p.317.

${ }^{113}$ Cf. ALONSO SCHÖKEL,L., Dicionário Bíblico Hebraico-Português, p. 482. O uso de עi junto à raiz יסף forma uma construção redundante que se procurou evitar na tradução.
} 


\begin{tabular}{|c|c|c|}
\hline "Eu não sou profeta & $14 \mathrm{c}$ & 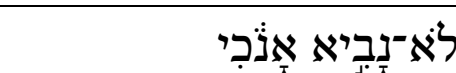 \\
\hline nem $^{114}$ filho de profeta; & $14 d$ & 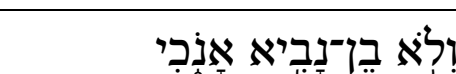 \\
\hline pois sou pastor ${ }^{115}$ & $14 \mathrm{e}$ & 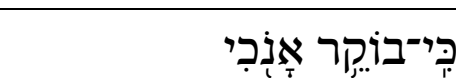 \\
\hline e cultivador de sicômoros. & $14 \mathrm{f}$ & וּבוֹלֵסס שִׁקְמָים: \\
\hline $\begin{array}{l}\text { Mas YHWH me tomou de detrás } \\
\text { do rebanho }\end{array}$ & $15 \mathrm{a}$ & 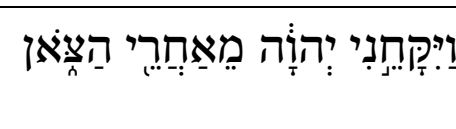 \\
\hline e YHWH disse-me: & $15 \mathrm{~b}$ & 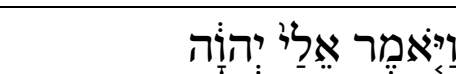 \\
\hline Vai! & $15 \mathrm{c}$ & 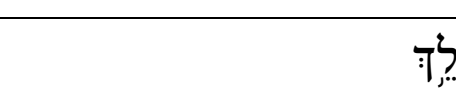 \\
\hline Profetiza ao meu povo Israel. & $15 \mathrm{~d}$ & 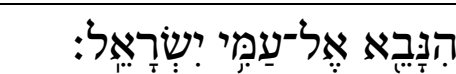 \\
\hline $\begin{array}{l}\text { E agora ouve a palavra de } \\
\text { YHWH: }\end{array}$ & $16 \mathrm{a}$ & 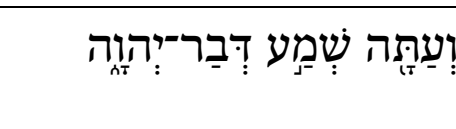 \\
\hline Tu dizes: & $16 \mathrm{~b}$ & 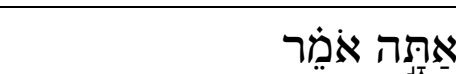 \\
\hline Não profetizes contra Israel & $16 \mathrm{c}$ & 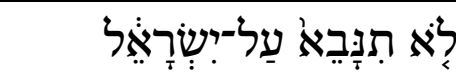 \\
\hline $\begin{array}{l}\text { nem vaticines }{ }^{116} \text { contra a casa de } \\
\text { Isaque. }\end{array}$ & $16 \mathrm{~d}$ & 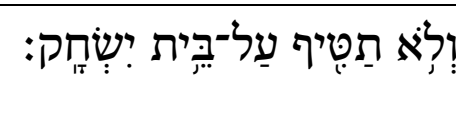 \\
\hline Por isso assim diz YHWH: & $17 \mathrm{a}$ & לָכָּן ذָה־אָמַר יְהָוֹה \\
\hline
\end{tabular}

${ }^{114}$ Uma possível tradução alternativa em 14d seria: "isto é, filho de profeta", devido ao fato do waw copulativum ter, possivelmente aqui, função explanatória, sendo também chamado de waw explicativum. Cf. COMLEY, A. E., Gesenius' Hebrew Grammar as Edited and Enlarged by the Late E. Kautzch, § 154b, nota b, pp. 484-485.

${ }^{115}$ Cf. ALONSO SCHÖKEL,L., Dicionário Bíblico Hebraico-Português, p. 94. Também significa boiadeiro, cf. HOLLADAY W, L., Léxico Hebraico Aramaico do Antigo Testamento, p.48. Cf. MARTENS, E, A., DITAT, p.276. Este termo refere-se àquele que cuida do gado graúdo (דฺָָּ

${ }^{116}$ Cf. ALONSO SCHÖKEL, L., Dicionário Bíblico Hebraico-Português, p. 433. O sentido básico deste verbo é gotejar, escorrer, destilar, pingar, manar, verter. Aqui, porém, está em sentido figurado. 


\begin{tabular}{|c|c|c|}
\hline $\begin{array}{l}\text { Tua mulher se prostituirá na } \\
\text { cidade, }\end{array}$ & $17 b$ & 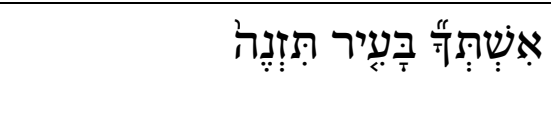 \\
\hline $\begin{array}{l}\text { teus filhos e tuas filhas cairão pela } \\
\text { espada, }\end{array}$ & $17 \mathrm{c}$ & 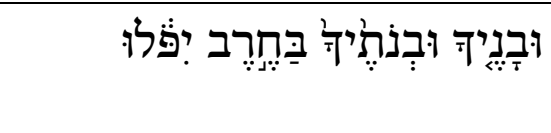 \\
\hline tua terra será repartida a cordel; & $17 d$ & 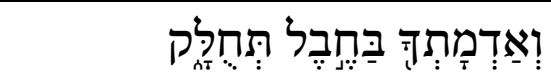 \\
\hline tu morrerás em terra impura & $17 \mathrm{e}$ & 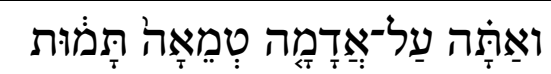 \\
\hline $\begin{array}{l}\text { e Israel certamente será deportado } \\
\text { de sua terra". }\end{array}$ & $17 \mathrm{f}$ & 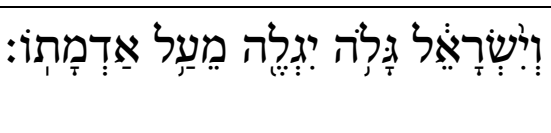 \\
\hline
\end{tabular}

$\mathrm{O} \mathrm{BHQ}^{\mathrm{App}}$ aponta as seguintes variantes de leitura nos versículos abaixo:

v.10

Em 10c a versão Siríaca omite palavras") ao invés de ("a terra não pode suportar todas as suas palavras") conforme o TM. Esta omissão, possivelmente, deve-se a uma abreviação porque considerou

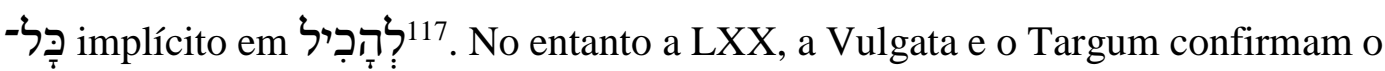
TM. Assim opta-se pelo TM do Códice Leningradense.

v.12

Em 12e aponta uma leitura distinta feita pela LXX que em lugar de וּקָכָלל-

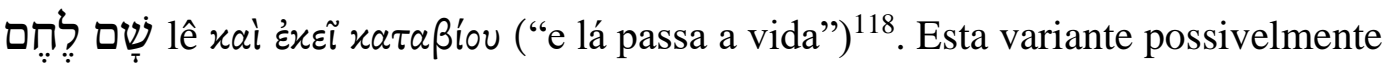
é resultado de interpretação do texto. Porém o TM do Códice Leningradense é confirmado pelo manuscrito 88 de Murabba'ât, pela Vulgata, pela versão Siríaca e pelo Targum. Opta-se assim pelo texto do Códice Leningradense.

${ }^{117}$ Cf. Commentary on The Critical Apparatus, in: BH Quinta, Fascicle 13: The Twelve Minor Prophets, p.86.

118 Cf. MURAOKA, T., A Greek-English Lexicon of The Septuagint, p.368. Também pode ser traduzido como: "e lá vive até o fim", cf. ISIDRO PEREIRA, S.J., Dicionário Grego-Português e Português-Grego, p. 299. 
v.13

O indica a ausência do sinal macrosintático ס no Códice de Alepo que considerou o v.14 no mesmo parágrafo do v.13. Mas o Manuscrito EBP do Códice Leningradense e o Códice dos Profetas do Cairo confirmam a presença do referido sinal macrosintático, considerando o v.14 no parágrafo seguinte. Assim é preferível o texto do Códice Leningradense.

v.14

A LXX e a versão Siríaca em 14e, a trazem aỉónos ("cabreiro") 119 onde o texto hebraico traz בּּוֹקֵר ("pastor"), possivelmente por assimilação ao contexto

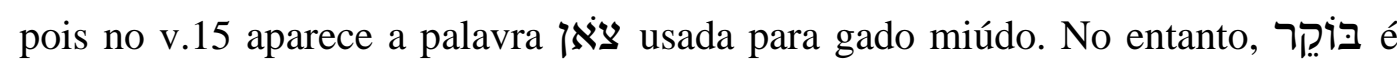
confirmado pelo Manuscrito Grego dos XII Profetas da quarta gruta de Qumran, pelas recensões de Áquila, de Símaco, de Teodocião, da Quinta, pela Vulgata e pelo Targum. Por ser a lição mais difícil, opta-se pelo TM do Códice Leningradense.

v.15

Há a ausência, em 15b, da preposição הِ הִ bem como há uma variante de em 15d no Manuscrito Grego dos XII Profetas da quarta gruta de Qumran; entretanto a LXX, a Vulgata, a versão Siríaca e o Targum confirmam o TM.

Há uma outra variante, ainda em 15d, onde lê-se עַל em lugar de constatada no manuscrito 88 de Murabba'ât, na versão Siríaca e no Targum. Tal variante deve-se provavelmente à assimilação ao contexto. O TM é confirmado pelo Manuscrito Grego dos XII Profetas da quarta gruta de Qumran, pela LXX e pela Vulgata. Em todos os casos de variantes textuais constantes no v.15 opta-se pelo Códice Leningradense porque tem o apoio de importantes documentos em todos os casos referidos.

\section{V.16}

A LXX e a recensão de Teodocião leram éđì ("sobre") ao invés de ("contra") na primeira ocorrência da preposição עַ, em 16c, provavelmente em função da assimilação ao contexto, pelo uso espacial da preposição עַל no versículo 17. No

\footnotetext{
${ }^{119}$ Cf. MURAOKA, T., A Greek-English Lexicon of The Septuagint; p.15. Cf. LIDDELL, H. G.; SCOTT, R., A Greek-English Lexicon, p.41. Cf. ISIDRO PEREIRA, S. J., Dicionário GregoPortuguês e Português-Grego, p. 18.
} 
entanto o TM está confirmado pelo Manuscrito 88 de Murabba'ât, pelo Manuscrito Grego dos XII Profetas da quarta gruta de Qumran, pelas recensões de Áquila e Símaco, pela Vulgata, pela versão Siríaca e pelo Targum.

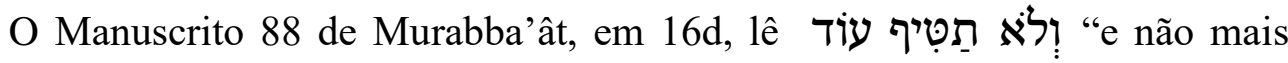
vaticinarás" em lugar de וְל תִִַּיף. Provavelmente houve uma ampliação pelo

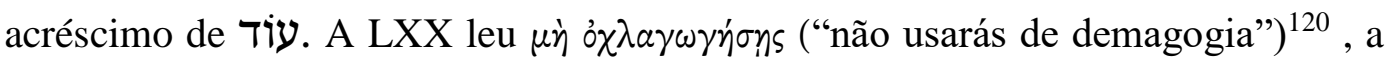

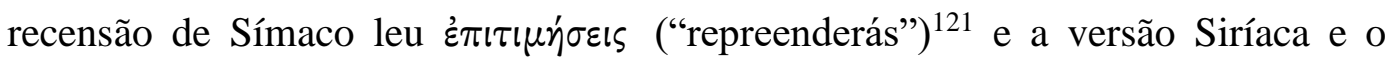
Targum lêem תַת תֵליף (“dar notícias, informar”). Todas estas leituras são possivelmente fruto de interpretação do texto. A favor do TM temos a recensão de Áquila e a Vulgata.

A LXX leu, em 16d, દ̇ $\pi \grave{i}$ ("sobre") ao invés de עַל- "contra" porque possivelmente houve assimilação ao contexto por causa do uso de עַ no v.17, ou em 16c, antes de "Israel". A versão Siríaca lê com lámed, possivelmente por causa de interpretação do texto. A Vulgata e o Targum testemunham a favor do TM.

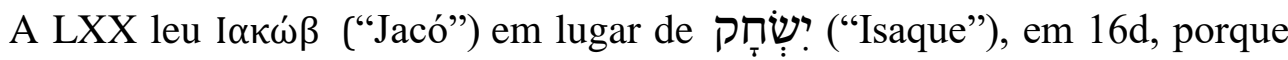
provavelmente houve assimilação ao nome mais usual ${ }^{122}$. A recensão de Áquila leu

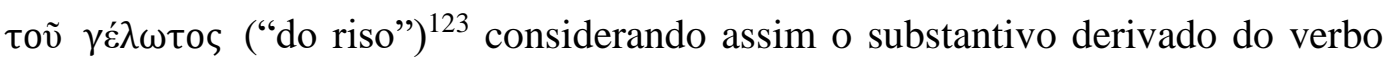
"rir" e não o nome próprio "Isaque"; já a Vulgata traz idoli, possível resultado de interpretação teológica do texto. A favor do TM testemunham as recensões de Símaco, Teodocião e Áquila mesmo que indiretamente, bem como a versão Siríaca e o Targum. Assim opta-se pelo TM do Códice Leningradense.

\section{v.17}

O Manuscrito Grego dos XII Profetas da quarta gruta de Qumran leu, em 17a, o nome divino composto יהוה אדני יהוה em vez de, provavelmente por ser uma expressão usual no livro. Porém a LXX, a Vulgata, a Siríca e o Targum concordam o texto massorético. Assim faz-se a opção pelo TM do Códice Leningradense.

\footnotetext{
${ }^{120}$ Cf. MURAOKA, T., A Greek-English Lexicon of The Septuagint, p.516. Envolve a ação de enganar o povo para fins de charlatanismo.

${ }^{121}$ Cf. MURAOKA, T., A Greek-English Lexicon of The Septuagint, p. 285.

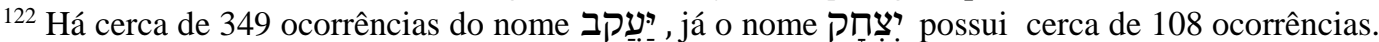

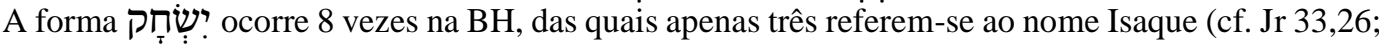
Am 7,9.16). As demais ocorrências referem-se ao verbo rir.

${ }^{123}$ Cf. MURAOKA, T., A Greek-English Lexicon of The Septuagint, p.126.
} 


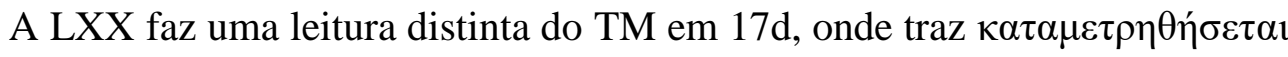
("será medida") ${ }^{124}$, mudando o significado do texto hebraico de "repartir" para “medir". Porém o Manuscrito Grego dos XII Profetas da quarta gruta de Qumran, as recensões de Áquila, Símaco e Teodocião, a Vulgata, a Siríaca e o Targum concordam com o TM. Assim prevalece o texto do Códice Leningradense.

\section{3.}

\section{Delimitação e Unidade de Am 7,10-17}

A delimitação dos vv.10-17 é indicada no TM do Códice Leningradense pela presença de uma petuhá no final de Am 7,9 apontando o início de uma seção nova no v.10. Am 7,9 pertence ao relato da terceira visão que tem início no v.7, no qual é descrita a visão de YHWH com um prumo sobre o muro de chumbo, prossegue no v.8 onde YHWH pergunta a respeito da visão e o profeta responde e termina no v.9 que conclui a unidade textual de Am 7,7-9.

A ruptura com a unidade textual precedente é também confirmada pela mudança de gênero literário, de um relato de visão em $1^{a}$ pessoa para um relato biográfico em $3^{a}$ pessoa. $\mathrm{O}$ aparecimento de personagem até então não mencionado, como Amasias, cujo nome aparece apenas nesta narrativa, e Jeroboão, que aparece no v.9 mas integrando a expressão "casa de Jeroboão" apontam igualmente para uma nova seção.

A narrativa inicia-se com Amasias fazendo uma acusação contra Amós ao rei Jeroboão. A acusação consistiu que Amós estava conspirando contra o monarca de Israel por causa da sua contundente mensagem (vv.10-11).

A narrativa prossegue nos vv.12-17, através do encontro-diálogo de Amasias com Amós. A presença de duas setumás ao longo da narrativa (v.11 e v.13) não indicam rupturas no texto, apenas apontam a mudança de quem faz uso da palavra que, no caso do v.12, é Amasias e no caso do v.14 é Amós. Então estas setumás indicam subunidades que integram o texto, pois a continuidade do texto fica

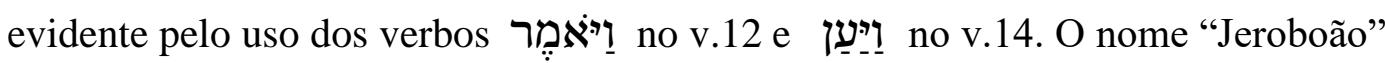

${ }^{124}$ Cf. MURAOKA, T., A Greek-English Lexicon of The Septuagint, p.377. 
ocorre nos vv.10-11 e a partir deste versículo não mais aparece na narrativa. O nome “Amós" ocorre nos vv.10,11,12 e 14. Já o nome "Amasias" ocorre nos vv.10,12 e 14 e referências a este nome aparece nos vv.16 e 17 pelo uso do pronome pessoal de $2^{\mathrm{a}}$ pessoa nos vv.16 e 17, bem como através dos sufixos de $2^{\mathrm{a}}$ pessoa no v.17: "tua mulher", "teus filhos e tuas filhas" e "tua terra". O nome "Israel" aparece nos vv.10 (2x), 11,15,16 e 17. O tema da palavra profética é também proeminente, נבא דaparecendo nos vv.10-17, pela ocorrência do substantivo e da raiz (4x). Estes dados revelam que o desenvolvimento da narrativa põe o foco na atitude do sacerdote de rejeitar a palavra profética bem como em suas consequências.

Os vv.16-17 encerram o relato anunciando as consequências que viriam sobre Amasias e sua família como resultado da rejeição à palavra proclamada por Amós.

O TM do Códice Leningradense ao final do v.17 traz uma setumá indicando o final da seção em Am 7,17 e início de outra em Am 8,1. Aqui há uma ruptura temática no texto com a mudança de gênero literário de relato biográfico para relato de visão, onde dá-se início a quarta visão que traz o tema do fim da nação.

Pelo que foi exposto conclui-se que o texto de Am 7,10-17 é uma unidade textual homogênea pois apresenta coesão temática e linguística, não apresentando tensões ou rupturas internas.

\section{4 .}

\section{Organização do texto}

O relato do encontro de Amós com o sacerdote Amasias inicia-se nos vv.1011 nos quais o sacerdote Amasias relata ao rei Jeroboão as palavras de Amós. Há um paralelismo termo a termo em v.10a através da correspondência dos

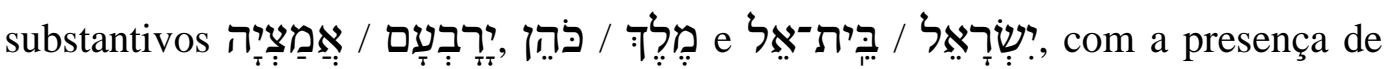

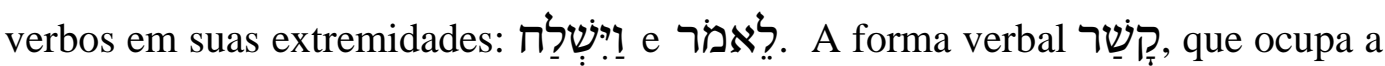
extremidade inicial do segmento 10b, corresponde ao substantivo na extremidade final de 10c: a conspiração suposta por Amasias reside nas palavras

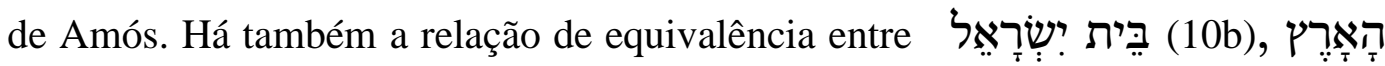
(10c) e אַדְמָת (11c), referências ao povo e ao local onde Amós desenvolve sua 
atividade profética. Em 10c há uma paronomásia que pode ser observada nos

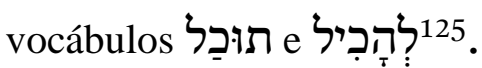

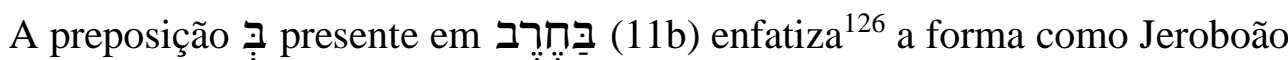

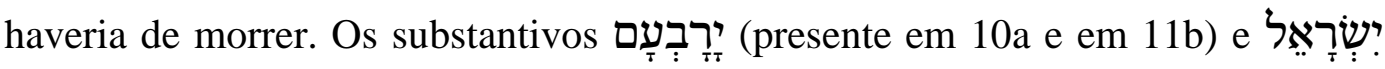
(10b e 11c) constituem os extremos dos vv.10-11, formando uma moldura. O centro

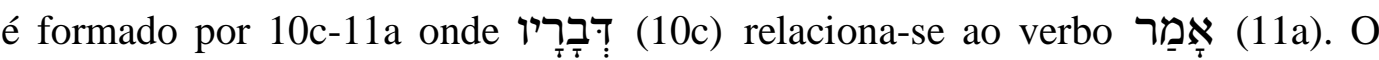
esquema abaixo mostra o que foi dito:

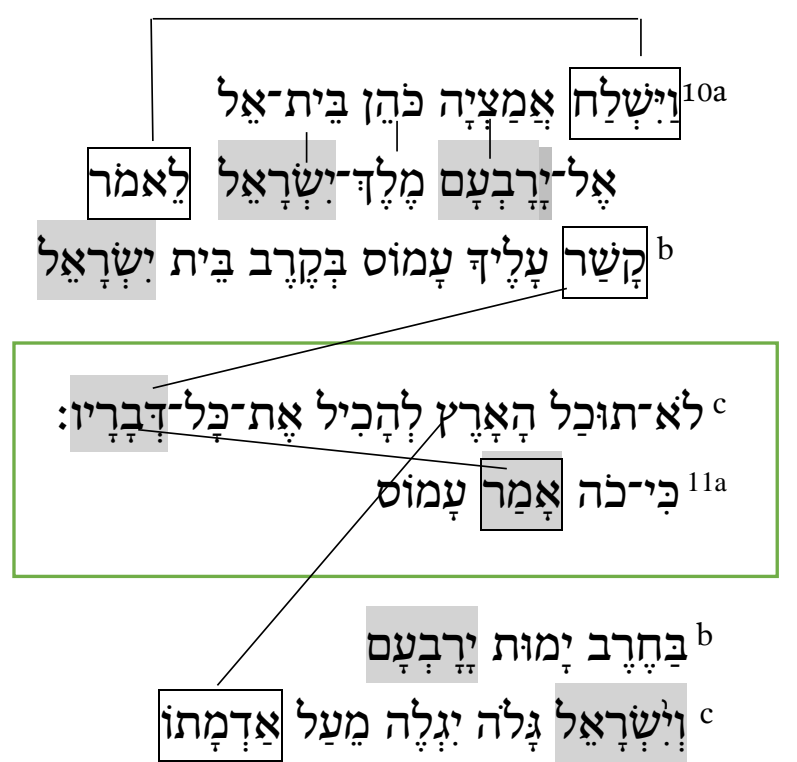

Amasias fala a Amós nos vv.12-13. É notável a sequência de imperativos no

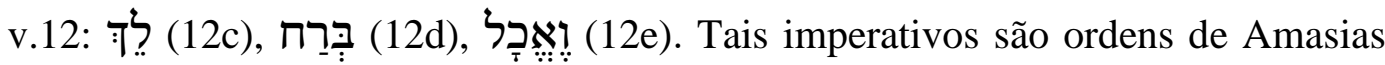
para Amós. Os segmentos $12 \mathrm{ef}$ são paralelos, com a presença da partícula adverbial שָׁ (12d) e conectados pela conjunção I. Os segmentos 12b-f estão em oposição a 13a, pois naqueles é dito para Amós profetizar mas neste é dito que não profetizasse mais. A explicação de 13a está em 13bc através da conjunção ?ִִ̣ .

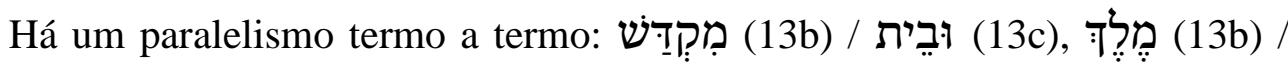

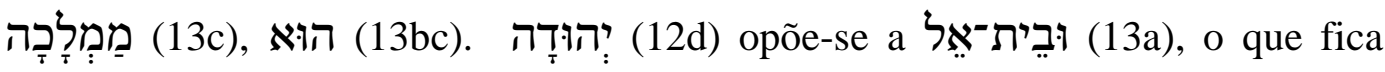
evidente pelo contraste do uso da partícula adverbial שָָ (12ef) que direciona para Judá em oposição a (13bc), uma referência ao santuário de Betel.

\footnotetext{
${ }^{125}$ BOVATTI, P.; MEYNET, R., Le Livre du Prophète Amos, p. 298. Também cf. SHALOM, M. P., A Commentary on the Book of Amos, p. 240.

${ }^{126}$ Cf. PAUL,S. M., A Commentary on the Book of Amos, p. 240.
} 
Amós fala a Amasias nos vv.14-17, sendo os vv.14-15 uma réplica de Amós

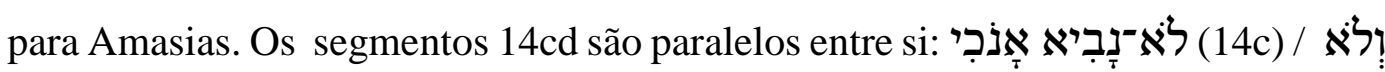

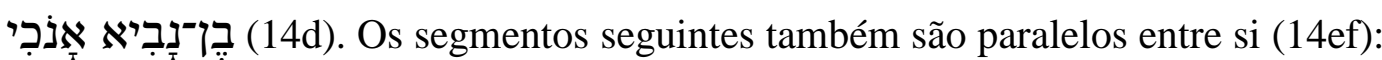

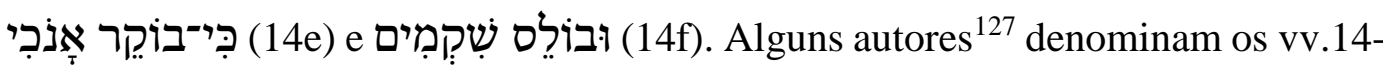
15 como a apologia de Amós na qual fala de sua experiência pessoal e chamado, sendo notáveis as três repetições do pronome (14) (14cde). Por outro lado, 14cd e 14ef estão em oposição evidenciando o contraste entre as atividades de profeta $\mathrm{x}$ boiadeiro. $\mathrm{O}$ verbo no imperativo לִ ocorre duas vezes nesta narrativa: a primeira, em 12c, que expressa a vontade de Amasias para Amós e a segunda ocorrência está em 15c expressando a vontade de YHWH para o profeta ${ }^{128}$. O substantivo

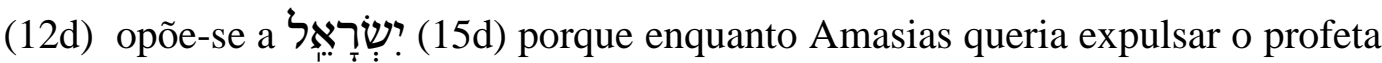
para a terra de Judá, lugar onde Amós nasceu, viveu e trabalhou, YHWH enviou Amós para a terra de Israel, lugar onde o seu ministério de profeta deveria atuar ${ }^{129}$. Os substantivos עַ (15a) (15a) são opostos entre si na medida em que YHWH retira o profeta do rebanho e o leva a profetizar ao povo de Israel. A raiz נבא dְבְיא duas vezes (14cd). Os extremos dos vv.12-15 são os segmentos $12 \mathrm{~cd}$ e $15 \mathrm{~cd}$ e o centro está em 13bc, pois expressa o motivo pelo qual Amós não podia profetizar ali.

O esquema abaixo ilustra o que dito:

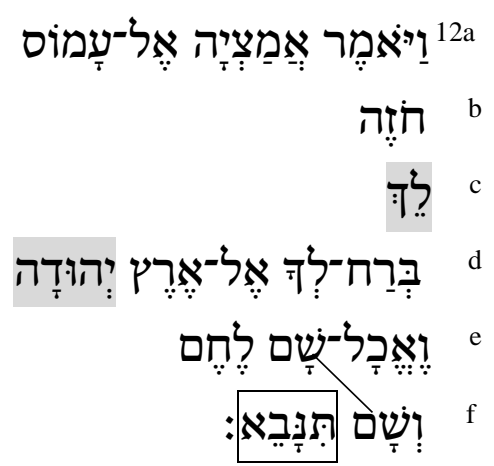

127 Cf. ANDERSEN, F. I., FREEDMAN, D. N., Amos: A New Translation with Notes and Commentary, p. 776.

128 Cf. BOVATTI, P., MEYNET, R., Le Livre du Prophète Amos, p. 302.

129 Cf. ANDERSEN, F. I., FREEDMAN, D. N., Amos: A New Translation with Notes and Commentary, p. 770. 

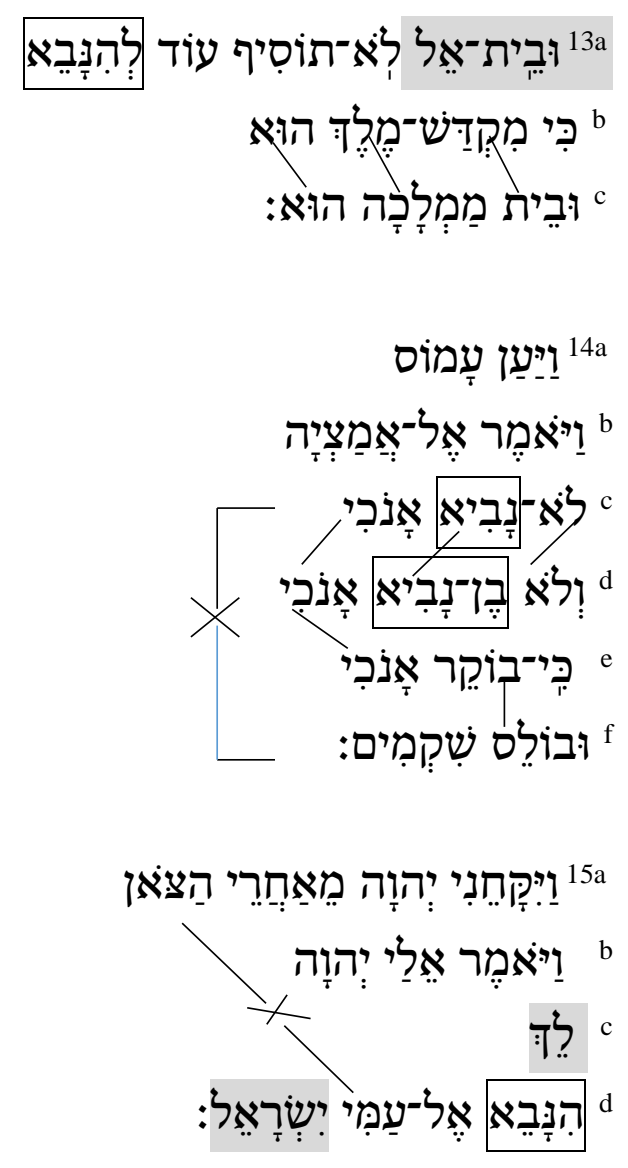

Encerrando a narrativa temos as palavras de Amós para Amasias citando as palavras de Amasias (16c-d) e citando a palavra de YHWH (v.17b-f). Há uma

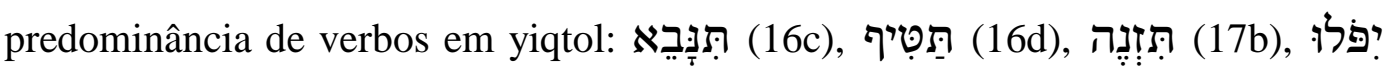

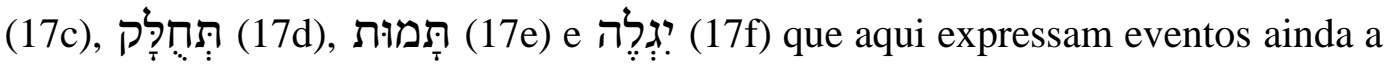
ocorrer no futuro. Os verbos em 16cd expressam proibições de Amasias para Amós e os demais (17b-f) expressam sentenças condenatórias de YHWH para Amasias, sua família, sua terra e sua nação, o que pode ser observado pela frequência do pronome de $2^{\mathrm{a}}$ pessoa em $16 \mathrm{~b}$ e $17 \mathrm{e}$ bem como pela presença do sufixo de $2^{\mathrm{a}}$ pessoa

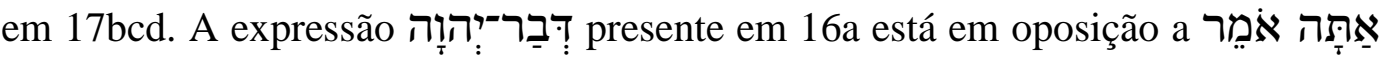
presente em 16b: a palavra de YHWH está em colisão com a palavra de Amasias. $16 \mathrm{c}$ e 16d são paralelos membro a membro: ambos iniciam com a partícula negativa

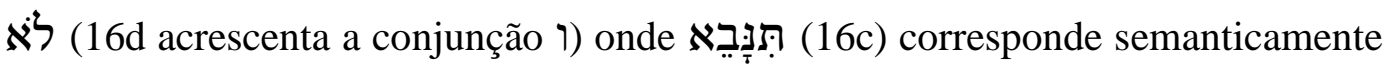

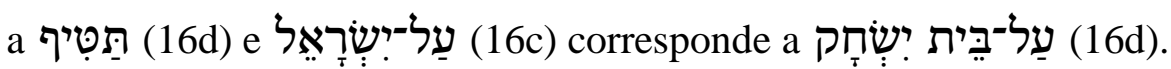


O segmento 17 a retoma 16 a através da fórmula do mensageiro. Há um padrão ${ }^{130}$ que se repete em $17 \mathrm{bcde}$ : sujeito - substantivo com preposição prefixada - verbo em yiqtol. Há um paralelismo entre 17b e 17c, onde

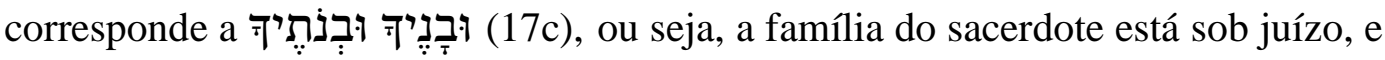
(17b) são raízes verbais que aqui expressam o tipo de juízo. Há

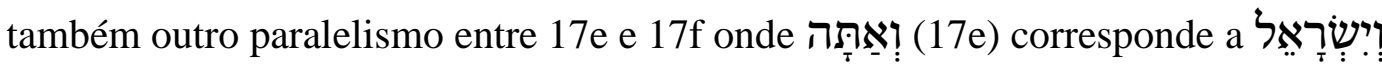
(17f) que quer dizer que o sacerdote Amasias e a nação de Israel compartilharão do

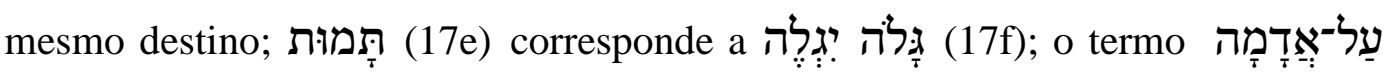
(17f), pois Amasias e sua nação serão deportados da terra sagrada de Israel para uma terra profana.

Há dois segmentos paralelos entre si no v.17: 17bc e 17ef, e entre eles está $17 \mathrm{~d}$ que não é paralelo a nenhum outro e por isso está no centro ${ }^{131}$ desta última parte

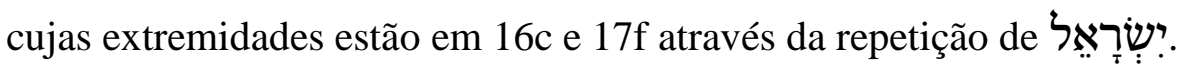

O que foi exposto pode ser visto no esquema abaixo:

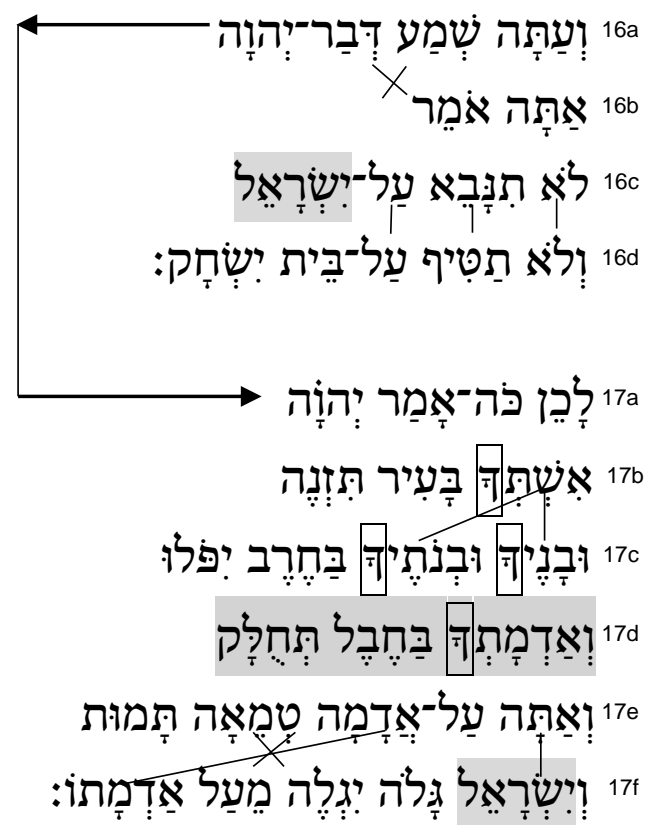

${ }^{130}$ Cf. ANDERSEN, F. I., FREEDMAN, D. N., Amos: A New Translation with Notes and Commentary, p. 777.

${ }^{131}$ Cf. BOVATTI, P., MEYNET, R., Le Livre du Prophète Amos, p. 303. 
Os vv. 16-17 constituem um oráculo de juízo individual ${ }^{132}$ proferido por Amós contra Amasias e que além de atingí-lo, incluiu também sua esposa, seus filhos e filhas, sua terra e seu povo. Os elementos que constituem este tipo de oráculo estão presentes nestes versículos ${ }^{133}:(1)$ em 16a temos um convite para ouvir a palavra; (2) em 16b-d há uma acusação; (3) em 17a há a fórmula do mensageiro e (4) em 17b-f há o anúncio propriamente dito.

\begin{tabular}{|c|c|c|}
\hline $16 \mathrm{a}$ & $\begin{array}{c}\text { Convite a ouvir a palavra de } \\
\text { YHWH }\end{array}$ & 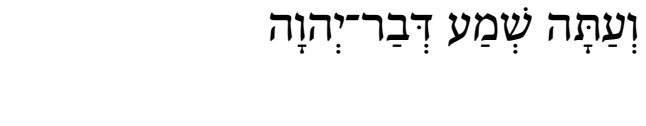 \\
\hline $16 b-d$ & Acusação & 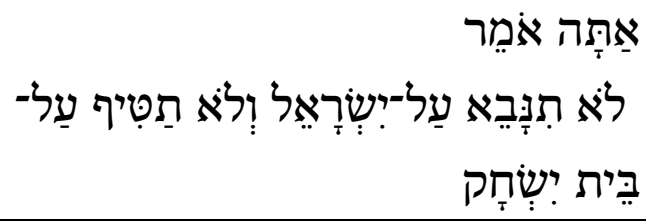 \\
\hline $17 \mathrm{a}$ & Fórmula do mensageiro & לְכְן פּה־אָמַר יְהוּה \\
\hline $17 b-f$ & Anúncio & 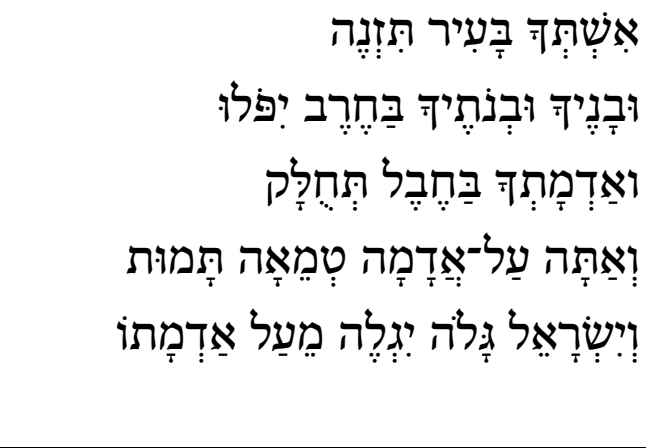 \\
\hline
\end{tabular}

\section{Tabela 8}

Oráculo de juízo individual em Am 7,16-17 e seus elementos constitutivos

A passagem considerada por inteiro tem extremidades em 11c e $17 \mathrm{f}$ pela

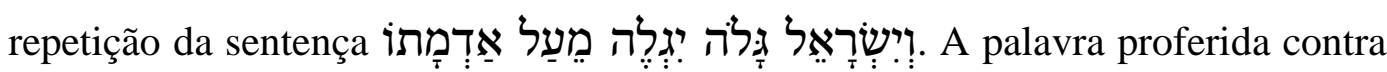
Jeroboão em $11 \mathrm{~b}$ tem o seu paralelo na palavra contra Amasias em 17e pela repetição das formas verbais derivadas da raiz יָמזוּת : (11b) e (17e).

Oח חֶרב ocorre em 11b contra Jeroboão e em 17c contra os filhos

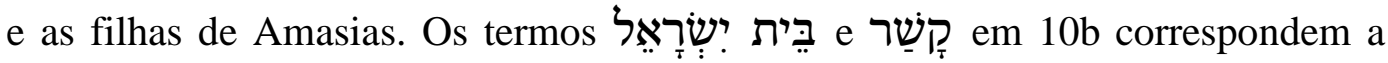

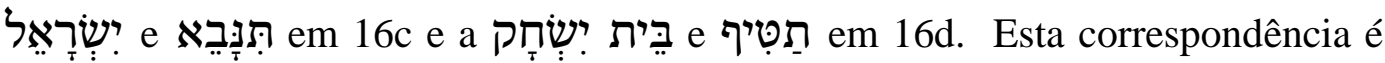

${ }^{132}$ WESTERMANN, C., Basic Forms of Prophetic Speech, pp. 142-163.

${ }^{133}$ Cf. LIMA, M. L. C., Mensageiros de Deus: Profetas e Profecias no Antigo Israel, p.100. 
justificada pela associação feita por Amasias, em 10bc, entre as palavras proféticas de Amós e uma suposta atividade conspiratória. O centro da narrativa está nos Vv.12-15.

O esquema abaixo mostra o que foi dito:

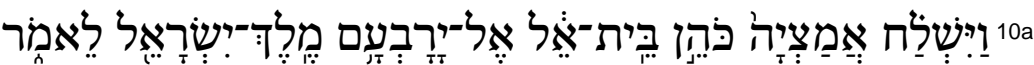

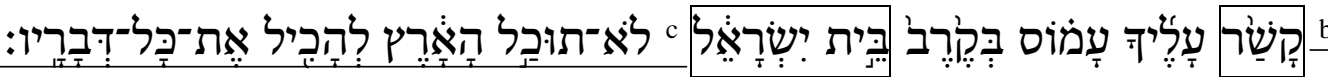

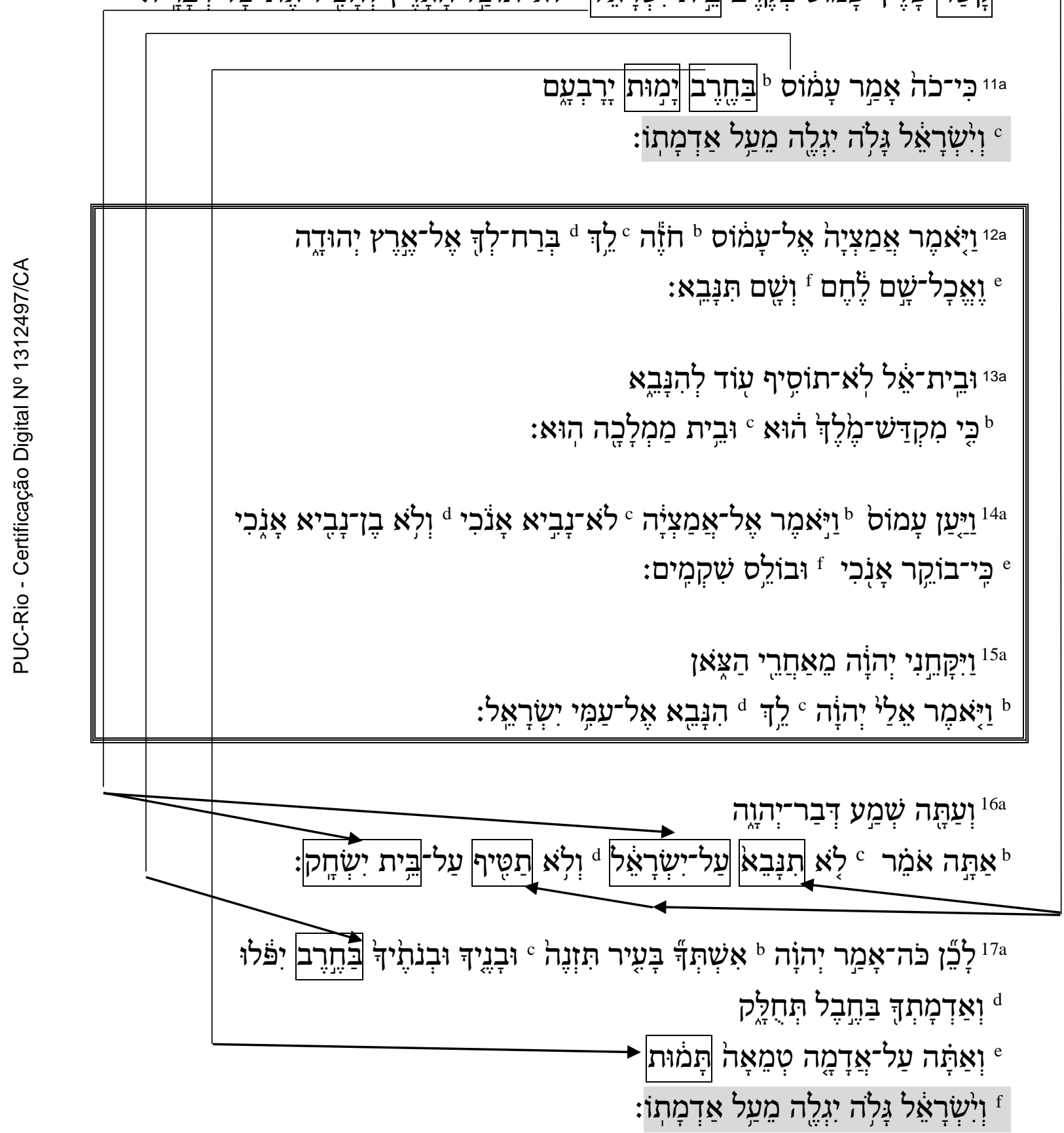


Pelo exposto conclui-se que a narrativa tem três partes, ou cenas ${ }^{134}$ : a primeira parte, que serve de introdução, está nos vv.10-11 e que consiste nas palavras de Amasias dirigidas a Jeroboão. No v.10 Amasias usa as suas próprias palavras ao acusar Amós de conspiração e no v.11 Amasias cita as palavras de Amós nas quais anuncia a morte de Jeroboão e a deportação da nação.

A segunda parte ou cena está nos vv.12-15 onde ocorre o confronto entre Amasias e Amós. Aqui há duas partes. Os vv.12-13 registram as palavras de Amasias a Amós, nas quais o sacerdote ordena a Amós que não profetize mais em Betel e que este fuja para Judá (cf. v.12) e a seguir justifica a sua proibição (cf. v.13). Nos vv.14-15 há a réplica de Amós a Amasias, na qual Amós fala a respeito da sua vida: quem ele não é e quem ele é; como foi chamado por YHWH e qual o comissionamento que dele recebeu.

A terceira e última parte está nos vv.16-17 onde Amós dirige a palavra à Amasias e também tem duas partes: o v.16 no qual Amós cita as palavras proibitivas de Amasias para que ele não profetize mais e o v.17 onde Amós cita a palavra de YHWH contra Amasias, sua família, sua terra e seu povo.

A tabela abaixo sintetiza o que foi dito:

\begin{tabular}{|l|c|c|c|c|}
\hline \multicolumn{5}{|c|}{ Estrutura de Am 7,10-17 } \\
\hline Vers. & $\begin{array}{c}\text { Quem usa } \\
\text { a palavra }\end{array}$ & $\begin{array}{c}\text { De quem são } \\
\text { as palavras }\end{array}$ & $\begin{array}{c}\text { O conteúdo das } \\
\text { palavras }\end{array}$ & $\begin{array}{c}\text { A quem é } \\
\text { dirigida } \\
\text { a palavra }\end{array}$ \\
\hline 10 & Amasias & Amasias & $\begin{array}{c}\text { Amós é acusado de } \\
\text { conspiração } \\
\text { Profecia contra } \\
\text { Jeroboão e Israel }\end{array}$ & Jeroboão \\
\hline
\end{tabular}

${ }^{134}$ Cf. WOLFF, H, W., Joel and Amos: A Commentary on the Books of the Prophets Joel and Amos, p. 308. Em geral, os autores concordam com esta tríplice divisão da estrutura: $1^{\mathrm{a}}$ cena: vv.10-11 (Amasias fala à Jeroboão); $2^{\mathrm{a}}$ cena: vv.12-13 (Amasias fala à Amós) e $3^{\mathrm{a}}$ cena: vv. 14-17 (Amós fala à Amasias). Assim também cf. PAUL, S. M., Amos: A Comentary on the Book of Amos, p. 238239. Bovatti também estrutura em três partes, com uma diferença: ele divide em dois momentos a fala de Amós: no primeiro momento da fala (vv.14-15) o referido autor a situa na segunda cena (vv. 12-15); já no segundo momento da fala, Amós toma a iniciativa e entrega um oráculo contra Amasias (vv.16-17). Cf. BOVATTI, P., MEYNET, R., Le Livre du Prophète Amos. P. 297. Neste trabalho optou-se por seguir Bovati (vv.16-17). Cf. BOVATTI, P.; MEYNET, R., Le Livre Du Prophète Amos, p. 297. Optou-se por seguir Bovatti e Meynet na estruturação do texto, dado o detalhamento da sua análise da forma e pelo fato dos vv.14-15 estarem relacionados com os vv.12-13, sendo uma resposta de Amós às colocações feitas por Amasias. 


\begin{tabular}{|c|c|c|c|c|}
\hline $12-13$ & Amasias & $\begin{array}{l}\text { Amós / } \\
\text { YHWH }\end{array}$ & $\begin{array}{l}\text { Ordem para Amós } \\
\text { fugir de Betel e não } \\
\text { profetizar mais ali } \\
\text { seguida de justificativa } \\
\text { Quem Amós não é e } \\
\text { quem ele é; como foi } \\
\text { chamado por YHWH e } \\
\text { a ordem que dele } \\
\text { recebeu para profetizar }\end{array}$ & Amasias \\
\hline 16 & Amós & Amasias & $\begin{array}{l}\text { A ordem proibitiva de } \\
\text { Amasias como } \\
\text { justificativa para a } \\
\text { profecia seguinte }\end{array}$ & Amasias \\
\hline 17 & & YHWH & $\begin{array}{c}\text { Profecia contra } \\
\text { Amasias, sua família, } \\
\text { sua terra, seu povo. }\end{array}$ & Amasias \\
\hline
\end{tabular}

Tabela 9

Estrutura de Am 7,10-17

\section{5}

\section{Semântica do texto}

\subsection{1.}

\section{Palavras de Amasias a Jeroboão (vv.10-11)}

\subsubsection{1.}

\section{Amasias acusa Amós de conspiração (v.10)}

O nome ocorrências estão na narrativa de Am 7,10-17 (cf. vv. 10.12.14). Ele era sacerdote ${ }^{135}$

\footnotetext{
135 Vários autores afirmam que Amasias era o principal sacerdote do santuário de Betel pelos seguintes motivos, dentre outros: (1) a expressão construta כَהַן בַּית é definida e portanto ele não era qualquer sacerdote, cf. STUART, D., Hosea-Jonah, p.375; MCCOMISKEY, T, E., The Minor Prophets - Vol 1: Hosea, Joel, and Amos, p.460. (2) Tinha acesso imediato ao rei. Cf. HUBBARD, A, D., Joel e Amós, p.238; JACOB, E.; KELLER, C. A.; AMSLER, S., Commentaire de L'Ancien Testament: Osée, Joël, Amos, Abdias, Jonas, p. 228-229. (3) Provalmente exercia funções de
} 
do santuário de Betel (cf. 10a) e enviou uma mensagem ${ }^{136}$ a Jeroboão II, rei de Israel, contendo uma séria acusação contra o profeta Amós ${ }^{137}$.

O sacerdote Amasias acusa Amós nos seguintes termos: קָשָׁר עָלֶיף עָמוֹס

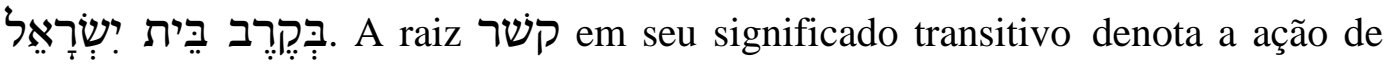
amarrar algo a alguma coisa ou a alguém (cf. Gn 38,28; Js 2.18.21) mas em seu significado estativo pode expressar a união de pessoas pela afeição (cf. Gn 44,30; $1 \mathrm{Sm} \mathrm{18,1)} \mathrm{ou} \mathrm{para} \mathrm{conspiração}{ }^{138}$. A raiz neste último sentido tem uso político e militar ${ }^{139}$ e expressa a associação de pessoas que se vincularam para depor e matar o rei com o propósito de usurpar o trono (cf. 1Rs 15,27; 16,9.20; 2Rs 9.14). As conspirações bem sucedidas normalmente exterminavam a família real inteira e faziam surgir uma nova dinastia, situações não raras no Reino do Norte ${ }^{140}$.

Havia precedentes para que a liderança política e religiosa de Israel ficasse alarmada $^{141}$ : segundo as tradições bíblicas, profetas já ungiram homens que depuseram dinastias vigentes em suas épocas, como foi o caso de Eliseu ao enviar um discípulo para ungir Jeú (2Rs 9,3.14) que iniciou uma dinastia nova da qual Jeroboão II fazia parte ${ }^{142}$. Amasias viu em Amós um elemento subversivo, um agitador político ${ }^{143}$ que oferecia sério perigo para o reino de Jeroboão II e o acusou de conspiração sobretudo por causa da palavra que Amós estava proclamando no seio da casa de Israel, que, possivelmente no parecer do sacerdote, tinha o mesmo efeito subversivo de uma conspiração política ${ }^{144}$.

supervisão, regulamentação e proteção da religião nacional, cf. WOLFF, H, W., Joel and Amos: A Commentary on the Books of the Prophets Joel and Amos, p.310; SMITH, V. G., Comentários do Antigo Testamento: Amós, p.343; ANDERSEN, F, I.; FREEDMAN, D, N., Amos: A New Translation With Notes and Commentary, p.766.

136 Am 7,10-11 contém provavelmente um resumo da mensagem do sacerdote Amasias ao rei Jeroboão II, o que pode ser observado pela ausência das fórmulas epistolares. Cf. ANDERSEN, F. I.; FREEDMAN, D.N., Amos: A New Translation With Notes and Commentary, p.766; GARRET, D. A., Amos: A Handbook On The Hebrew Text, p. 218.

137 Tradições remontam à época do profeta Amós, embora o texto possa ser redacionalmente posterior. Cf. WOLFF, H, W., Joel and Amos: A Commentary on the Books of the Prophets Joel and Amos, p. 108.

${ }^{138}$ Cf. COOPES, J. L., "קשר", DITAT, p. 1380-1381.

${ }^{139}$ Cf. SIMIAN-YOFRE, H., Amos:Nueva Versione, Introduzione e Commento, p. 155; BOVATTI, P., MEYNET, R., Le Livre du Prophète Amos, p. 298.

${ }^{140}$ Cf. CONRAD, J., "קשרר", TDOT, vol. 13, p. 199.

${ }^{141}$ Cf. JACOB, E.; KELLER, C. A .; AMSLER, S., Osée, Joël, Amos, Abdias, Jonas: Commentaire de L'Ancien Testament, vol 1,:, p. 228.

${ }^{142}$ Cf. PAUL, S. M., Amos: A Comentary on the Book of Amos, p. 239.

${ }^{143}$ Cf. NOBLE, R. N., "Amos and Amaziah in Context: Synchronic and Diachronic Approaches to Amos 7-8", The Catholic Biblical Quarterly, vol. 60, n 3, p. 428. Noble argumenta que em nenhum momento o texto dá a entender que Amasias viu em Amós um autêntico profeta de YHWH mas sim um conspirador que utiliza-se da atividade profética para fins políticos (cf. Am 7,10) e financeiros (cf. Am 7,12).

${ }^{144}$ Cf. CONRAD, J., “קשר", TDOT, vol. 13, p. 199. 
O receio de Amasias com respeito à atividade profética de Amós foi a ponto

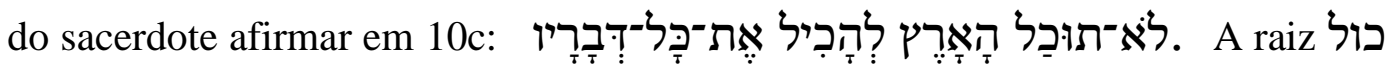
ocorre 38 vezes $^{145}$ na $\mathrm{BH}$ e entre estas aparece 12 vezes no hifil ${ }^{146}$, grau no qual a raiz descreve a capacidade que dado recipiente contém em termos de volume de água $^{147}$, como a descrição do mar de fundição e da pia de bronze do templo de Salomão (1 Rs 7,26.38; 8.64). Em Jr 2,13 as cisternas rotas que o povo fez para si não retiveram (כול) as águas. Em seu sentido metafórico a raiz כול torna-se uma figura de tolerância - resistência, ocorrendo no livro de Jeremias onde o profeta vê a si mesmo como um vaso que não é capaz de conter a ira divina (cf. Jr 6,11; 10,10).

A única ocorrência da raiz כול no livro de Amós está em Am 7,10 e está em sentido figurado: Amasias retrata a terra como um vaso ${ }^{148}$ cuja medida está completamente cheia, prestes a explodir por causa da pressão exercida pela mensagem do profeta $^{149}$.

Aqui entende-se אֶּר como sendo uma entidade geopolítica, ou seja, a nação de Israel, no reino de norte, considerada com as suas instituições oficiais e respectivos representantes, com o seu povo e com o seu território ${ }^{150}$.

Pode-se saber que a referida terra é a terra de Israel pelas referências indicadas no contexto: (1) no v.10b, há a acusação de que Amós conspira dentro da "Casa de Israel"; (2) no v.13a, Amasias proíbe Amós de profetizar em "Betel”; (3) no v.15d, YHWH ordena o profeta, que era do reino do sul, profetizar ao "meu povo Israel"; (4) e em v.16d, "Casa de Isaque" há um paralelismo sinonímico membro a membro com v.16c, onde "Casa de Isaque" é sinônimo de Israel.

\subsubsection{2.}

\section{Amasias cita as palavras de Amós a Jeroboão (v.11)}

A fundamentação da acusação de Amasias contra Amós está no v.11 ${ }^{151}$. Amasias fez uma possível paródia ${ }^{152}$ com a convencional fórmula oracular do

\footnotetext{
${ }^{145}$ Cf. OSWALT, J. N., “כול", DITAT, p.706; Também cf. BAULMANN, A., "כול", TDOT, p. 86.

${ }^{146}$ Referências da BH onde כול aparece no hifil: 1Rs 7,26.38; 8,64; 2Cr 4,5; 7,7; Jr 2,13; 6,11; 10,10; Ez 21,33; 23,32; Jl 2,11 e Am 7,10.

${ }^{147}$ Cf. KONKEL, A. H., "כול", DITEAT, p. 614.

${ }^{148}$ Cf. PAUL, S. M., Amos: A Comentary on the Book of Amos, p. 240.

${ }^{149}$ Cf. BAUMANN, A., "כול", TDOT, Vol. 7, p. 88.

${ }^{150}$ Cf. MCCOMISKEY, T, E., The Minor Prophets - Vol 1: Hosea, Joel, and Amos, p.460.

${ }^{151}$ Cf. SMITH, G., Comentário do Antigo Testamento: Amós, p. 344.

152 Cf. ANDERSEN, F. I.; FREEDMAN, D. N., Amos: A New Translation With Notes and Commentary, p.768.
} 


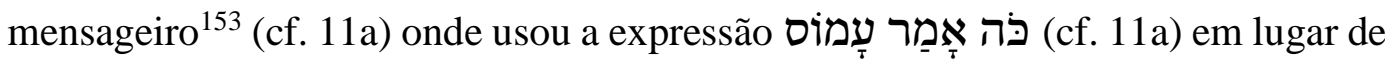

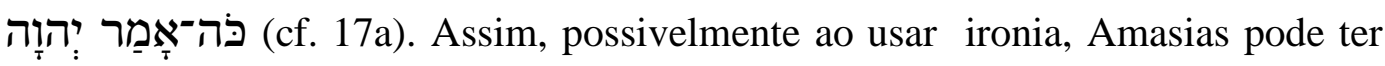
insinuado ao rei que Amós era um insurgente e não arauto de $\mathrm{YHWH}^{154}$ pelo fato de sugerir que Amós falava por si mesmo.

O sacerdote de Betel cita, supostamente, as palavras de Amós nestes termos:

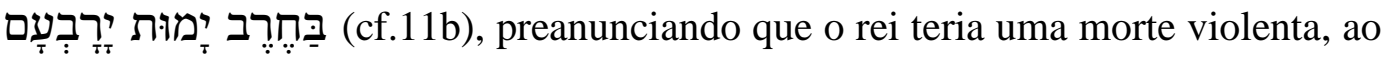
usar a expressão "pela espada"155. É possível que seja uma referência a Am 7,9156 onde o oráculo expressamente afirma que a espada seria levantada contra a "casa de Jeroboão". Para Andersen e Freedman bem como para Hubbard, não há diferença entre "Jeroboão" e "casa de Jeroboão" por causa do entendimento hebraico da estreita identificação da pessoa com sua família e assim um termo poderia incluir o outro. Já Wolff entende que o v.9 é uma revisão posterior para acomodar o fato de que Jeroboão não morreu assassinado e sim um descendente dele ${ }^{157}$ (cf. 2Rs 15.811).

Apesar do contexto demostrar claramente que não se trata de insurreição e sim de punição divina, Amasias interpretou a mensagem como sedição contra o reino $^{158}$, utilizando as palavras de Amós como fundamento para a sua acusação.

A outra citação feita por Amasias encontra-se em 11c na qual menciona o

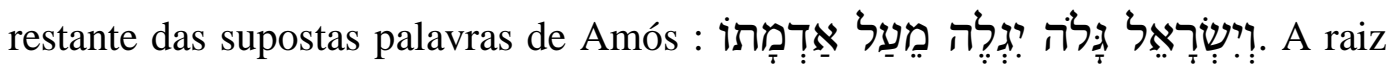
no qal significa descobrir, revelar, ir embora, ir ao exílio ${ }^{159}$. Ocorre 187 vezes na $\mathrm{BH}$ e no sentido de ir ao exílio ocorre 74 vezes $^{160}$. A referida raiz neste mesmo

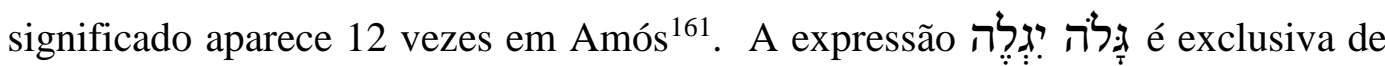

\footnotetext{
${ }^{153} \mathrm{O}$ conceito da fórmula oracular do mensageiro é tratado nas pp. 75-76 deste trabalho.

${ }^{154}$ Cf. ALONSO SCHÖKEL, L., SICRE DIAZ, J. L., Profetas, Vol. 2, p. 1017.

155 O termo חֶרֶ ocorre 9 vezes em Amós, todas as ocorrências em contexto de juízo; Am 1,11; 4,10; 7,9.11.17; 9,1.4.10.

${ }^{156}$ As únicas referências à Jeroboão no livro de Amós fora da presente perícope narrativa estão em Am 1,1; 7,9.

157 Cf. ANDERSEN, F, I.; FREEDMAN, D, N., Amos: A New Translation With Notes and Commentary, p. 768; Cf. HUBBARD, D. A., Joel e Amós: Introdução e Comentário, p. 238.. Cf. WOLFF, H, W., Joel and Amos: A Commentary on the Books of the Prophets Joel and Amos, p.310. ${ }^{158}$ Cf. PAUL, S. M., Amos: A Comentary on the Book of Amos, p. 239-240. Paul faz mais algumas observações com respeito a citação que Amasias faz de Amós: (1) que não incluiu em sua citação as causas pelas quais a dinastia de Jeroboão haveria de ser derrubada; (2) não menciona as ameaças aos santuários de Israel (aproxidamente dois terços dos oráculos). Paul sugere que ao omitir o que diz respeito a si e ao concentrar-se nas ameaças ao rei, Amasias teria ocultado seus interesses pessoais.

${ }^{159}$ Cf. WESTERMANN, C.; ALBERTZ, R., “גלה", DTMAT, p.596.

${ }^{160}$ Cf. HOWARD, D. M., "גלה", NDITEAT, vol 4, pp. 835-836.

161 Cf. WALTKE, B. K., “גלה", DITAT, p. 264. Em Amós esta raiz aparece em: Am 1,5.6; 3,7; $5,5.27 ; 6,7 ; 7,11.17$.
} 
Amós ocorrendo além do v.11 também em Am 5,5 e Am 7,17. A referida expressão denota a certeza ${ }^{162}$ do exílio na Assíria.

\section{5 .2}

\section{O confronto entre Amasias e Amós (vv.12-15)}

\subsubsection{1.}

\section{Amasias fala a Amós (vv. 12-13)}

Amasias dirige a palavra ${ }^{163}$ a Amós nesta segunda cena e o chama de חזֶ, forma nominal ${ }^{164}$ derivada da raiz חזה, de origem aramaica ${ }^{165}$, que possui os seguintes significados: ver, ter uma visão, olhar, contemplar, perceber, observar. A raiz refere-se tanto a visão natural dos olhos como às visões sobrenaturais ${ }^{166}$. Na BH a raiz חזה relaciona-se, em particular, com a raiz נבא: em alguns textos profetas têm visões e em outros visionários profetizam ${ }^{167}$, sendo este último o caso da narrativa em estudo, especificamente dos vv.12-17. A utilização da raiz põe em relevo a revelação recebida pelo a forma nominal חזְֶ significa vidente ou visionário e ocorre 17 vezes ${ }^{169}$, sendo associada, quando no singular, a algum nome em 11 passagens da BH: a Gade (2Sm 24,11; 1Cr 21,9; 29,29; 2 Cr 29,25); a Hemã (1Cr 25,5); a Asafe (2Cr 29,30); a Jeú (2Cr 19,2); a Jedutum $(2 \mathrm{Cr} 35,15)$, a Ido $(2 \mathrm{Cr} 9,29 ; 12,15)$ e a Amós $(\mathrm{Am} 7,12)$." $\Rightarrow$ "a Gade (cf. 2Sm 24,11; 1Cr 21,9; 29,29; 2Cr 29,25); a Hemã (cf.1Cr 25,5); a Asafe (cf. 2Cr 29,30); a Jeú (cf. 2Cr 19,2); a Jedutum (cf. 2Cr 35,15), a Ido (cf. 2Cr

${ }^{162}$ Quando uma forma verbal está no infinitivo absoluto junto a verbo finito, ambos de mesma raiz, o sentido da raiz é reforçado. Cf. COMLEY, A. E., Gesenius' Hebrew Grammar as Edited and Enlarged by the Late E. Kautzch, §113.3, p.342.

${ }^{163}$ É assunto controverso entre os autores se o texto diz que Amasias dirige-se a Amós com a resposta do rei Jeroboão ou se falou com Amós a partir de sua própria autoridade. Paul observa que o texto não deixa claro esta questão por não ser este o propósito da narrativa. Cf. PAUL, S. M., Amos: A Commentary on the Book of Amos, 240. Já Bovatti e Meynet entendem que as palavras de Amasias expressam a vontade do rei. Cf. BOVATTI, P. ; MEYNET, R., Le Livre du Prophète Amos, p. 309. 164 VETTER, D., "חזה", DTMAT, p.745. Cf. MCCOMISKEY, T. E., The Minor Prophets: An Exegetical and Expository Commentary, p. 461.

${ }^{165}$ Cf. JPESEN, A., "חזדה", TDOT, vol 4, p. 280.

${ }^{166}$ Cf. NAUDÉ, J. A., "חזדז", NDITEAT, vol 2, p. 56.

${ }^{167}$ LIMA, M. L. C., Mensageiros de Deus: Profetas e Profecias no Antigo Israel, p. 61. Os seguintes textos da BH exemplificam profetas tendo visões: Ez. 13,4.6-9; 22,28; Os 12,11; Mq 3,6; Hab 1,1; Lm 2,14.

${ }^{168}$ LIMA, M. L. C., Mensageiros de Deus: Profetas e Profecias no Antigo Israel, p. 61.

${ }^{169}$ Cf. JPESEN, A., "חָָזָ", TDOT, vol 4, p. 282. Na BH aparece nas seguintes passagens:

2 Sm 24,11; 2Rs 17,13; 1 Cr 21,9; 25,5; 29,29; 2 Cr 9,29; 12,$15 ; 19,2 ; 29,25 ; 29,30 ; 33,18 ; 35,15$; Am 7,12; Mq 3,7; Is 28, 15; 29,10; 30,10. 
9,29; 12,15) e a Amós (cf. Am 7,12). Um חזֶ pode estar bem próximo ao rei, sendo-lhe um conselheiro como no caso de Gade, o visionário de Davi, mas esta porém, não era a situação de todos ${ }^{170}$.

Alguns autores ${ }^{171}$ vêem Amasias reconhecendo a autenticidade do ministério de Amós ao chamá-lo de חזֶ; há outros ${ }^{172}$ que pensam que Amasias não demostrou nenhum apreço por ele, por considerá-lo como aquele que profetiza em troca de pão; porém há ainda outros ${ }^{173}$ que afirmam que o texto não permite chegar a conclusão alguma no que concerne à percepção interior do sacerdote Amasias em relação à Amós, argumentando que a questão central desta narrativa é a atitude do representante da religião de Israel para com o representante da palavra de YHWH. Independentemente do conceito que Amasias possuía em relação ao profeta Amós, o título de חזֶֶ é coerente com a atividade de Amós ${ }^{174}$ : a raiz חזה ocorre no título do livro (cf. Am 1,1) de forma positiva, ao situar Amós como um mediador profético que recebe uma visão; além disso a narrativa está situada dentro do ciclo das visões, onde Amós é descrito como aquele que recebe as visões ${ }^{175}$ da parte de $\mathrm{YHWH}^{176}$.

A raiz do conflito entre Amós e Amasias está no significado do que é ser um profeta. Para Amasias a profecia está a serviço da coroa real e profetas são profissionais que sobrevivem às custas de sua atividade e que portanto escolhem onde exercê-la e procuram não ofender seus patrocinadores ${ }^{177}$. Amós negou ser um

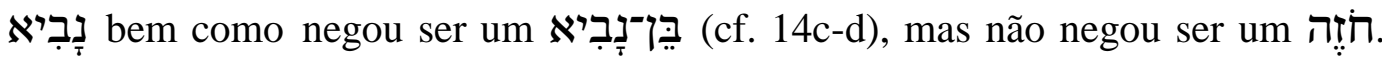
Atua como profeta porque profetiza (cf. Am 7,13.15.16), como visionário (cf. Am

\footnotetext{
${ }^{170}$ LIMA, M. L. C., Mensageiros de Deus: Profetas e Profecias no Antigo Israel, p. 62.

${ }^{171}$ É o caso de Wolff. Este autor vê Amasias como um homem que está oscilando entre a autoridade de rei e a autoridade de YHWH que está em Amós, e que por isso aconselha a Amós para retirar-se de Betel e voltar para Judá, a fim de evitar um confronto com o rei cf. WOLFF, H, W., Joel and Amos: A Commentary on the Books of the Prophets Joel and Amos, p.311. Também pensam assim Jacob, Keller e Amsler, cf. JACOB, E.; KELLER, C. A.; AMSLER, S., Commentaire de L'Ancien Testament: Osée, Joël, Amos, Abdias, Jonas, p. 230.

${ }^{172}$ É o caso de SICRE, J. L., Profetismo em Israel: O profeta, Os Profetas, A Mensagem, p.77.

${ }^{173}$ Cf. JEPSEN, A., TDOT, vol 4, p. 286. Também Cf. ANDERSEN, F, I.; FREEDMAN, D,N., Amos: A New Translation With Notes and Commentary, p.771. Para estes autores é possível que Amasias, ao chamar Amós de ז̊n, tenha reconhecido sua autoridade profética, mas reconhecem que há também a possibilidade de um tratamento desdenhoso.

${ }^{174}$ Cf. SIMIAN-YOFRE, H., Amos:Nueva Versione, Introduzione e Commento, p. 156.

175 Ainda que a raiz que aparece nos relatos de visão seja ראה (cf. Am 7,1.4.7.8; 8,1.2; 9,1) e não חזה, estas raízes pertencem ao mesmo campo semântico, possuindo significado similar. Cf. JEPSEN, A., TDOT, vol IV,p. 281.

${ }^{176}$ Cf. ANDERSEN, F. I.; FREEDMAN, D, N., Amos: A New Translation With Notes and Commentary, p.771.

${ }^{177}$ Cf. BOVATTI, P. ; MEYNET, R., Le Livre du Prophète Amos, p. 310.
} 
1,1) e como vidente (cf. Am 7,1.4.7; 8,1.2; 9,1), mas não está ligado a nenhum grupo profissional. Amós é um חị individual ${ }^{178}$.

O sacerdote Amasias ${ }^{179}$ ordena $^{180}$ a Amos que este fuja de Betel para Judá ${ }^{181}$,

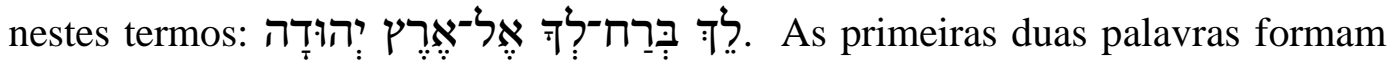
uma hendíades ${ }^{182}$, expressão única na $\mathrm{BH}$, significando que Amós deveria retirarse imediatamente ${ }^{183}$ para a terra de Judá. A expressão בִּרִ ocorre em outras duas passagens (cf. Gn 27,13 e Nm 24,11) ambas em contextos de perigo iminente para aquele a quem é dirigida a ordem: no primeiro caso Jacó e no segundo Balaão. Há elementos em comum entre $\mathrm{Nm} 24,11$ e Am 7,12 ${ }^{184}$ : (1) há a revelação divina por meio de visão; (2) esta revelação é entregue fora da terra natal do profeta; (3) a mensagem não é do agrado da autoridade que ouve; (4) a autoridade ofendida ordena a fuga do profeta para a sua terra de origem.

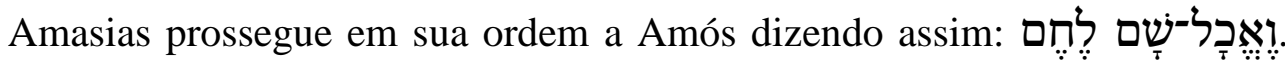

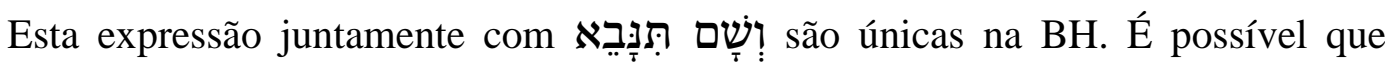
Amasias tenha usado de provocação ${ }^{185}$ aqui ao insinuar que Amós entregasse oráculos em troca de pão, como se este fosse o seu sustento. Há passagens que registram homens trazendo oferendas aos mediadores proféticos (cf. 1Sm 9,8; 1Rs $14,3 ; 2 \mathrm{Rs} 4,42 ; 2 \mathrm{Rs} 8,9)$ mas havia aqueles que profetizavam em troca de donativos e normalmente falavam mentiras (cf. Mq 3,5-7; Ez 13,19). Como será visto adiante

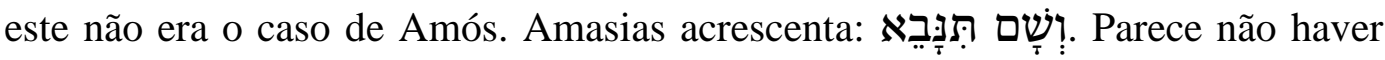
problema para Amasias se Amós continuasse seu ministério em outros lugares, sobretudo em Judá ${ }^{186}$, para onde ordenou que fosse profetizar ${ }^{187}$.

\footnotetext{
${ }^{178}$ Cf. LIMA, M. L. C., Mensageiros de Deus: Profetas e Profecias no Antigo Israel, p.74-78.

${ }^{179}$ Wolff descreve o sacerdote Amasias como um mediador do conflito entre Amós e o rei Jeroboão, sendo solidário ao profeta ao aconselhá-lo a fugir para a terra de Judá. Cf. WOLFF, H, W; Joel and Amos: A Commentary on the Books of the Prophets Joel and Amos, p.311. Andersen discorda veementemente. Cf. ANDERSEN, F, I.; FREEDMAN, D,N., Amos: A New Translation With Notes and Commentary, p.773.

${ }^{180} \mathrm{O}$ texto não deixa claro se Amasias agiu sob ordens de Jeroboão ou se foi por iniciativa própria. Cf. PAUL, S. M., Amos: A Comentary on the Book of Amos, p. 240.

${ }^{181}$ Sweeney compara a expulsão de Amós de Betel com a expulsão de Jeremias do templo de Jerusalém ao argumentar que Amasias tomou as palavras de Amós como séria ameaça. Cf. SWEENEY, M. A., The Twelve Prophets, p. 258.

${ }^{182}$ Cf. GARRETT, D. A., Amos: A Handbook on the Hebrew Text, p. 220.

${ }^{183}$ Cf. MCCOMISKEY, T, E., The Minor Prophets - Vol 1: Hosea, Joel, and Amos, p.461.

${ }^{184}$ Cf. ANDERSEN, F, I.; FREEDMAN, D,N., Amos: A New Translation With Notes and Commentary, p.772. Também cf. PAUL, S. M., Amos: A Comentary on the Book of Amos, p. 242. ${ }^{185}$ Cf. PAUL, S. M., Amos: A Comentary on the Book of Amos, p. 242.

186 Cf. ANDERSEN, F, I.; FREEDMAN, D,N., Amos: A New Translation With Notes and Commentary, p.774.

${ }^{187}$ A raiz נבא é abordada na p.72 deste trabalho.
} 
O versículo 13 informa-nos que a questão principal para Amasias está relacionada ao local onde Amós estava proclamando כי O O Supervisor do santuário nacional de Betel proibiu expressamente o profeta de exercer sua atividade em Betel e os motivos são os que seguem:

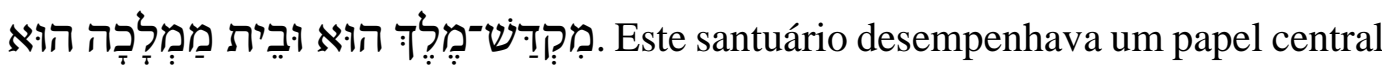
na vida da nação do ponto de vista político e religioso ${ }^{189}$, servindo como elemento de unidade nacional ${ }^{190}$ e por isto estava sob a jurisdição direta do rei Jeroboão II $^{191}$. $\mathrm{O}$ rei tinha as seguintes prerrogativas no santuário de Betel ${ }^{192}$ : (1) nomear o supervisor do santuário; (2) estabelecer os demais sacerdotes; (3) oferecer sacrifícios e queimar incenso.

Era politicamente conveniente que não houvesse perturbações naquele lugar, o que não estava efetivamente acontecendo com a mensagem de Amós. A respeito de Betel, Amós já havia anunciado: (1) que seus altares cairiam (cf. Am 3,14); (2) que cultuar ali é transgressão (cf. Am 4,4); (3) que será desfeito em nada (cf. Am 5,5), ou seja, destruído, tanto o santuário quanto a casa real (cf. Am 7,9).

Amós tornou-se potencialmente nocivo para o reino do norte, uma ameaça à sua estabilidade, e, no parecer de Amasias, um possível fomentador de uma conspiração contra o rei ${ }^{193}$. A proclamação de Amós o tornou persona non grata ${ }^{194}$ em Betel, e por extensão, em toda a nação de Israel.

\subsubsection{2.}

\section{Amós responde a Amasias (vv.14-15)}

Amós responde ao sacerdote de Betel: (14cd). Amós nega ser um נָבְביא. Oְבִיא

${ }^{188}$ Cf. WOLFF, H. W., Joel and Amos: A Commentary on the Books of the Prophets Joel and Amos, p.311.

${ }^{189}$ Cf. AMSLER, S., Commentaire de L'Ancien Testament: Osée, Joël, Amos, Abdias, Jonas, p. 230.

${ }^{190}$ Cf. BOVATTI, P., MEYNET, R., Le Livre du Prophète Amos, p. 310.

${ }^{191}$ Cf. SOUTHWELL, P. J. M., "בֵית־" NDITEAT, vol. 4, p. 434. O santuário nacional de Betel foi estabelecido por Jeroboão I (cf. 1Rs 12,31-33) para fazer oposição ao reino de Judá e ao templo em Jerusalém. O referido rei estabeleceu dois bezerros de ouro para adoração, um em Dã e outro em Betel tornando, assim, sincrético o culto a YHWH (cf. 1Rs 12,28-30).

192 Cf. AMSLER, S., Osée, Joël, Amos, Abdias, Jonas : Commentaire de L'Ancien Testament, p. 228.

193 Cf. BOVATTI, P.; MEYNET, R., Le Livre du Prophète Amos, p. 308.

${ }^{194}$ Cf. BOVATTI, P.; MEYNET, R., Le Livre du Prophète Amos, p. 309. 
atribuída ao verbo acadiano $n a b u^{\prime 195}$, tem o sentido de nomear, chamar. Tem sido assunto de discussão entre os estudiosos se o sentido do substantivo é ativo ou passivo, no entanto, ultimamente tem prevalecido o sentido passivo ${ }^{196}$. Um נָביא então é alguém chamado pela divindade à qual está servindo para ser mediador entre a palavra divina e os homens. Este substantivo é o que mais frequentemente designa figuras proféticas ${ }^{197}$, ocorrendo 315 vezes na $\mathrm{BH}$ e 5 vezes no livro de Amós: Am 2,11.12; 3,7; 7,14 (2x).

O título de נָבְיא tem diversas acepções dependendo se aparece no singular ou no plural. No singular e acompanhado do artigo definido referere-se a personagens individuais como Gad e Natan (cf. 2Sm 7,2; 12,25; 1Rs 1,8) que são pertencentes a corte real, como aqueles que não têm vínculo algum com a corte mas que são ocasionalmente procurados por reis ou seus representantes ou mesmo por sacerdotes ${ }^{198}$ : Aías de Silo (cf. 1Rs 11,29; 14,2.18), Jeú (cf. 1Rs 16,7.12), Elias (cf. 1Rs 17-19,21); 2Rs (1, 2-17) e Eliseu (cf. 1Rs 19,19-21; 2Rs 2-8; 9,1-13; 13,1421), um discípulo de Eliseu (cf. 2Rs 9,4), Jonas (cf. 2Rs 14,25), Isaías (cf. 2Rs 19,2; 20,1.11,14), Hulda (cf. 2Rs 22.14-20) e Débora (cf. Jz 4,4). Mesmo no singular o termo נָבְיא pode apresentar um sentido coletivo (cf. Jr 18,18; Ez 7,26-27; Is 3,23) e nestes casos o נָבְביא está entre as classes influentes da nação.

Já no plural, ְְּבְִִִים, refere-se a um grupo de profetas ou trata-se de uma designação geral. Quando se referem a um grupo podem ser distinguidos entre aqueles formados entre o período dos juízes e o início da monarquia e aqueles formados no período de Elias e Eliseu ${ }^{199}$. Este primeiro grupo de דְּבְִאים tinha as seguintes características: andavam em bandos (cf. 1Sm 10,5.10), reuníam-se em casa (cf. 1Sm 19,20), utilizavam-se de instrumentos musicais para exercerem suas atividades proféticas (cf. 1Sm 10,5) e entravam em êxtase atribuído ao espírito de YHWH (cf. 1Sm 10,6).

Especialmente importante para o estudo em questão é o outro grupo

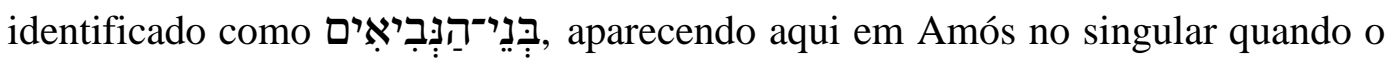

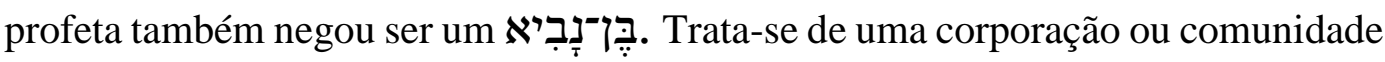
de profetas (cf. 2Rs 2,3.5.7.15; 4,1; 6,1). O propósito desta corporação de profetas

\footnotetext{
195 Cf. VERHOEF, P. A., "Profecia", NDITEAT, p. 1068.

196 Cf. JEREMIAS, J., "נָָבְיא", In: DTMAT, p. 24.

197 Cf. LIMA, M. L. C., Mensageiros de Deus: Profetas e Profecias no Antigo Israel, pp. 56-57. Apesar de נָבִיא ser o substantivo que mais frequentemente designa as figuras proféticas na $\mathrm{BH}$,

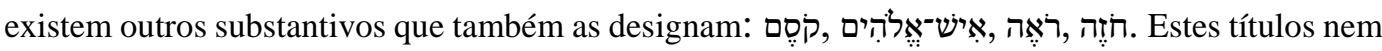
sempre são empregados com sentido positivo. No caso de קסֶֶם o sentido é sempre negativo. ${ }^{198}$ Cf. LIMA, M. L. C., Mensageiros de Deus: Profetas e Profecias no Antigo Israel, p. 58. ${ }^{199}$ Cf. VERHOEF, P. A., "Profecia", In: NDITEAT, vol. 4, p.1072.
} 
reunida em torno de Samuel, Elias ou Eliseu era seguir seus ensinos, preservando a mensagem destes profetas. Os discípulos dos profetas, em geral, não recebiam palavras diretamente de $\mathrm{YHWH}$, mas eram comissionados pelos profetas aos quais serviam $^{200}$ (cf. 2Rs 9,1).

Havia ainda grupos de profetas ligados à corte real. Estes grupos de profetas eram consultados pelo rei e convenientemente profetizavam palavras favoráveis ao regente (1Rs 22,6-8). São retratados de forma de forma negativa ${ }^{201}$ (cf. Jr 5,31; 13,13; Ez 13,3.9).

Sintetizando, pode-se dizer que havia os seguintes tipos de profetas: (1) profetas individuais diretamente ligados ao reino ${ }^{202}$, que serviam ao rei com seus oráculos e conselhos; (2) grupos de profetas que assistiam ao rei na corte, (3) profetas ligados ao templo que exerciam funções cúlticas; (4) profetas vinculados a determinadas corporações reunidas em torno de um profeta, também chamados filhos dos profetas; e por fim (5) profetas individuais que não eram vinculados a nenhuma instituição. Os três primeiros integravam a classe dirigente da nação e eram profissionais que recebiam seus sustentos a partir de suas atividades.

Os estudiosos consideram que os vv.14-15 ${ }^{203}$ são os mais controvertidos do livro de Amós. A questão gira em torno de qual é o tempo correto para traduzir 14c e 14d, se no passado ou no presente, bem como o papel da conjunção ḷ e da partícula לא. Esta questão ocorre pela aparente contradição entre o que é dito no v.14c-d e o que é afirmado no v.15: como pode Amós não ser profeta (cf. 14c) nem discípulo de profeta (cf. 14d) e ainda assim ser levantado por YHWH para profetizar (cf. 15d)? Wolff ${ }^{204}$ entende que o contexto dos vv.14-15 indicam que não há evidência de interesse em contrastar o passado e o presente na vida de Amós. Müller ${ }^{205}$

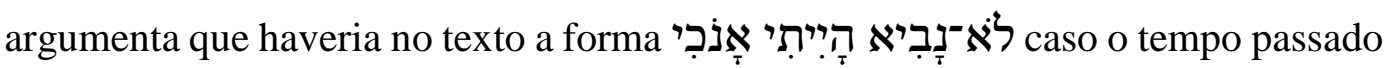
estivesse em foco. O presente trabalho segue Wolff, ao traduzir estas cláusulas nominais no tempo presente por parecerem mais naturais ao texto, considerando que o v.14 é determinado pelos vv.12-13. Deve-se considerar, além disso, que o

${ }^{200}$ Cf. WOLFF, H, W., Joel and Amos: A Commentary on the Books of the Prophets Joel and Amos, p.315.

${ }^{201}$ Cf. LIMA, M. L. C., Mensageiros de Deus: Profetas e Profecias no Antigo Israel, p.60.

${ }^{202}$ Cf. LIMA, M. L. C., Mensageiros de Deus: Profetas e Profecias no Antigo Israel, p.68.

${ }^{203}$ Cf. PAUL, S. M., Amos: A Comentary on the Book of Amos, p. 244. Também cf. SMITH, B. K.; PAGE, F. K., Amos, Obadiah, Jonah, vol 19b: An Exegetical and Theological Exposition of the Holy Scripture, p. 139. Para uma visão mais abrangente das possibilidades das cláusulas nominais de Am 7,14 ver HASEL, G. F., Understanding The Book of Amos: Basic Issues in Corrent Interpretations, Michigan, Baker Book House, 1991, p. 41-47.

${ }^{204}$ Cf. WOLFF, H, W., Joel and Amos: A Commentary on the Books of the Prophets Joel and Amos, p.311-312.

205 Cf. MÜLLER, H. -P., "“נָבְיא", TDOT, vol. 9, p.138. 
waw do v.14d pode ser entendido como waw explicativo ${ }^{206}$ que explicita ou explica o sentido da primeira cláusula: "não sou profeta, isto é, não sou filho de profeta". Assim, a atividade profética de Amós não deriva de um título de profeta oficialmente reconhecido mas de uma intervenção inesperada de $\mathrm{YHWH}^{207} \mathrm{em}$ sua vida, quando deu-lhe a comissão de profetizar, sendo Amós pastor e colhedor de sicômoros.

Os vv. 14-15 consistem em uma resposta de Amós à ordem dada por Amasias para que ele fugisse para Judá e lá viesse a sustentar-se de sua atividade profética. A resposta de Amós teve o objetivo de corrigir a avaliação que o sacerdote fez a respeito dele e consiste, mediante três clásulas nominais, afirmar quem ele não é (14c-d) e quem ele é (14e-f). Ao afirmar não ser profeta ${ }^{208}$ em 14c bem como não ser discípulo de profeta em 14d, Amós demostrou não ter vínculo com qualquer instituição, seja a corte real, seja o templo, seja uma corporação de $\operatorname{profetas}^{209}$. Amós pretendeu deixar claro que não era um profeta cúltico ou profissional, rejeitando, assim, qualquer identificação com essas figuras proféticas. Além disso, sua resposta deixa claro que não tem nenhum interesse em aferir ganhos econômicos por meio dos seus oráculos, fato não raro entre aqueles que exerciam atividade profética (cf. Mq 3,5; Ez 13,19).

Para Amós um profeta é chamado a partir de outra atividade, quando recebe um comissionamento para ser um mensageiro, e neste caso não escolhe a quem anunciar nem onde proclamar, mas sim fazer a vontade daquele que o chamou, YHWH.

Após afirmar quem ele não é (cf. 14c-d), Amós afirma quem é (cf. 14e-f):

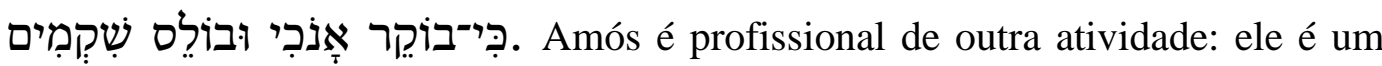

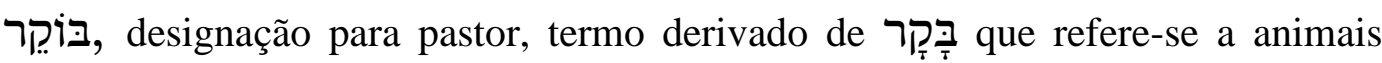

\footnotetext{
${ }^{206}$ Cf. ERLANDSSON, S., Några exempel på Waw Explicativum, In: Svensk Exegetisk Årsbok, vol. 41-41, 1976, pp. 69-76. Cf. COMLEY, A. E., Gesenius' Hebrew Grammar as Edited and Enlarged by the Late E. Kautzch, § 154b, nota b, pp. 484-485. Lewis defende que, no caso da sentença em Am 7,14, não há diferença entre os termos "profeta" e "filho de profeta" porque, segundo o referido autor, as cláusulas nominais $14 \mathrm{c}$ e $14 \mathrm{~d}$ conectadas por waw estão em paralelismo sinonímico, onde "filho de profeta" é um semitismo para o termo profeta. Cf. LEWIS, J. P., "A Prophet's Son (Amos 7:14) Reconsidered", Restoration Quarterly, vol. 49, n 4, 2007, pp. 235-239. ${ }^{207}$ Cf. JEREMIAS, J., Amos: Introduzione e Commento, p. 182.

${ }^{208}$ Segundo VIBERG, Amós usou de ironia ao negar ser profeta. Segundo o entendimento deste autor a ironia é um recurso amplamente utilizado no livro (cf. Am 3,1-2; 4,1.4-5; 5.18-20; 6,1.6-7) Amós teria usado de ironia ao humilhar-se diante de Amasias para que a autoridade de YHWH sobre ele fosse evidenciada. Cf. VIBERG, A., "Amos 7,14: a case of subttle irony", pp.107-113, In: Tyndale Bulletin 47.1, 1996, pp. 91-114.

209 Cf. ANDERSEN, F, I. - FREEDMAN, D, N; Amos: A New Translation With Notes and Commentary, p.777.
} 
domésticos: bois, vacas, touros e bezerros. נקָּ compõe o mesmo campo semântico da palavra ذָקָד que aparece na forma plural em Am 1,1 e na forma singular em 2 Rs 3,4, únicas ocorrências deste substantivo em toda a BH. Em 2 Rs 3,4 נפקָ é usado em relação ao rei de Moabe. Este fato levanta a possibilidade de Amós ser mais que um simples pastor, e aponta para um proprietário de rebanhos, um criador de gado $^{210}$, alguém proeminente ${ }^{211} \mathrm{em}$ Tecoa e portanto compunha o quadro de pessoas prósperas da sua época ${ }^{212}$. Além de pastor, Amós identifica-se

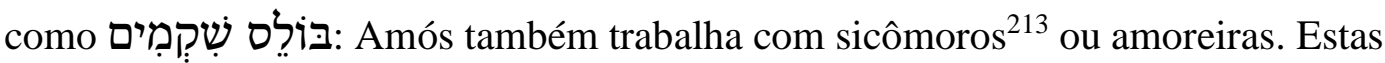
árvores não são encontradas nas regiões próximas de Tecoa ${ }^{214}$, dependem de clima quente e por isso crescem abundantemente na regiões costeiras do mar Mediterrâneo e no vale do Jordão ${ }^{215}$ (cf. 1Rs 10,27. S1 78,47; 1Cr 27,28). Este fato provavelmente levou Amós a ter contato com a realidade social, econômica e espiritual de locais fora de Tecoa ${ }^{216}$.

Portanto, Am 7,14 é uma resposta de Amós ao que Amasias lhe disse em Am 7,12: ao unir "comer pão" e "profetizar" (cf. Am 7,12) Amasias insinuou que Amós dependia financeiramente do profetismo; Amós, ao falar de sua atividade profissional no v.14 deixou claro que não aferia ganhos com sua atividade profética porque tinha outras fontes de renda: vivia do gado e dos sicômoros.

A seguir no v.15 Amós relata a Amasias a experiência do seu chamado. Durante a sua atividade quotidiana, entre os pastores de Tecoa (cf. Am 1,1), em

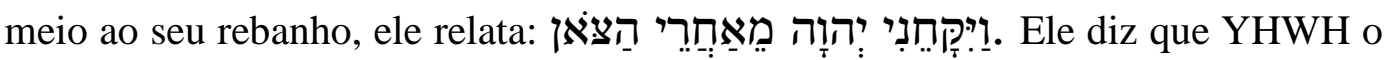

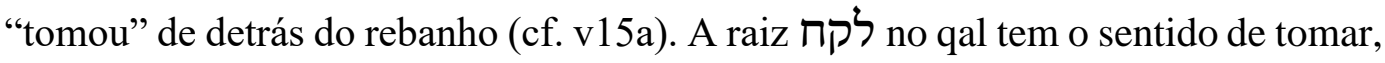
agarrar. Nos textos onde YHWH é o sujeito, o sentido de לקח pode ser o de escolher, selecionar. Tais textos põem em relevo a eleição e a soberania daquele que escolhe: YHWH tomou Israel para ser seu povo (cf. Ex 6,7), sua herança (cf. Dt 4,20); tomou os levitas para um serviço exclusivo para si (cf. Nm 3,12; 18,6); tomou Jeroboão para ser rei de Israel (cf. 1Rs 11,37), tomou Davi de suas ocupações

${ }^{210}$ Cf. SWEENEY, M. A., The Twelve Prophets, p.197.

${ }^{211}$ Cf. WOLFF, H, W., Joel and Amos: A Commentary on the Books of the Prophets Joel and Amos, p.124.

${ }^{212}$ Cf. WOLFF, H, W., Joel and Amos: A Commentary on the Books of the Prophets Joel and Amos, p.314. Já Schwantes discorda que Amós fosse abastado financeiramente, porque, argumenta Schwantes, o exercício de diversas ocupações e de trabalhos sazonais era típico da classe campesina pauperizada. Cf, SCHWANTES, M., A Terra Não Pode Suportar Suas Palavras (Am 7,10-17): Reflexão e Estudo sobre Amós, p. 51-52. Seja como for, Amós não vivia a partir do profetismo.

${ }^{213}$ Smith citando um estudo de Wright sugere que Amós utilizava os figos para alimentar o rebanho. Cf. SMITH, G., Comentário do Antigo Testamento: Amós, p.348

${ }^{214}$ Cf. PAUL, S. M., Amos: A Comentary on the Book of Amos, p.247.

${ }^{215}$ Cf. SMITH, G., Comentário do Antigo Testamento: Amós, p.348.

${ }^{216}$ Cf. HUBB ARD, D. A., Joel e Amós: Introdução e Comentário, p.242. 
para ser rei (cf. 2Sm 7,8) e tomou Amós de detrás do rebanho para uma missão na terra de Israel (cf Am 7,15).

Particularmente interessante para este estudo é comparar este relato do chamado de Amós no v.15 com o relato do chamado de Davi em 2Sm 7,8 e perceber que há raízes e palavras que são comuns à ambos.

As raízes e palavras que se repetem são colocadas em destaque no quadro comparativo abaixo:

\begin{tabular}{|c|c|}
\hline $\begin{array}{c}\text { Amós 7,15 } \\
\text { O chamado de Amós }\end{array}$ & $\begin{array}{c}2 \operatorname{Sm} 7,8 \\
\text { O chamado de Davi }\end{array}$ \\
\hline 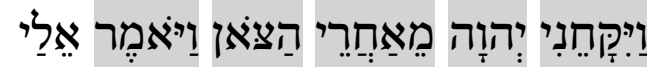 & 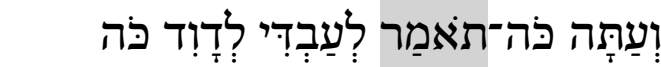 \\
\hline \multirow[t]{2}{*}{ 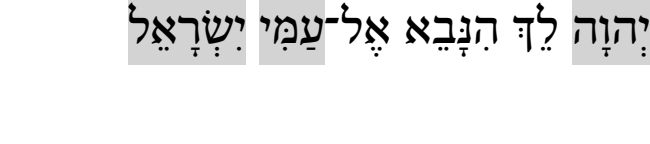 } & 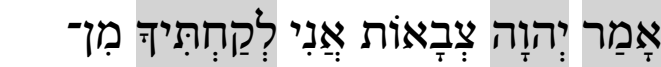 \\
\hline & 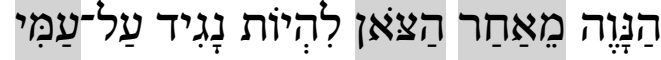 \\
\hline
\end{tabular}

Tabela 10

Quadro comparativo de Am 7,15 e 2Sm 7,8

YHWH é o sujeito do verbo tomar, לקח, em ambos os textos. Amós e Davi estavam envolvidos com seus trabalhos de pastorear o rebanho ${ }^{217}$, צאי, antes dos respectivos chamados; ambos não possuíam formação nem treinamento para a tarefa para a qual foram comissionados; no entanto, por vontade de YHWH foram escolhidos para uma missão junto ao povo de Israel, a quem YHWH chama "meu

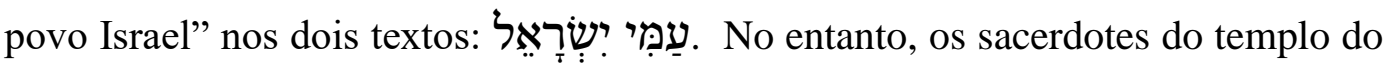
reino do norte eram estabelecidos diretamente por Jeroboão (cf. 1Rs 12,31).

Provavelmente Amós quis ensinar uma lição ${ }^{218}$ ao sacerdote de Betel que acabara de proibí-lo de profetizar ali: verdadeiros reis, sacerdotes ou profetas não são estabelecidos por vontade humana mas somente pelo desígnio soberano de YHWH (cf. Dt 17,15; 18,15).

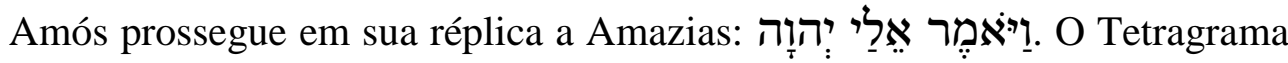
Sagrado aparece quatro vezes na narrativa (cf. 15a, 15b, 16a e 17a), sempre nos

\footnotetext{
${ }^{217}$ A BH registra, além de Davi e Amós, o caso de Moisés, outro ex-pastor de ovelhas que trabalhando no campo recebeu o chamado de YHWH para uma missão específica (cf. Ex 3,1ss).

${ }^{218}$ Cf. MCCOMISKEY, T, E., The Minor Prophets: An Exegetical and Expository Commentary Vol I, Hosea, Joel and Amos, p.463.
} 
lábios de Amós. A finalidade da repetição do Tetragrama, possivelmente, é para enfatizar o caráter divino de sua vocação, atribuindo a YHWH toda a responsabilidade do seu comissionamento e toda a autoridade das suas palavras. Amós estava em Betel não em seu próprio nome ou autoridade, mas como representante e porta-voz de YHWH.

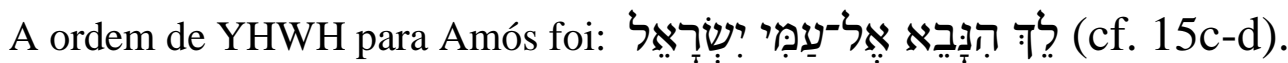
O verbo de raiz נבא נָבִיא é provavelmente denominativo do substantivo e tem significado essencial de falar como um profeta, comportar-se como um profeta, agir como um profeta, profetizar. É encontrado no nifal e no hitpael ${ }^{219}$. O nifal designa a maioria das ocorrências da palavra profética (cf. Jr 19,14; 26,18; Zc 13,3), já o hitpael refere-se aos aspectos mais externos e visíveis da atividade profética incluindo o êxtase (cf. 1Sm 19,24; 1Rs 18,29) - razão pela qual o hitpael é mais frequente nos textos mais antigos ${ }^{220}$ da BH. A raiz נבא ocorre em Amós seis vezes, exclusivamente no nifal (cf. Am 2,12; 3,8; 7,12.13.15.16).

A frequência desta raiz na história do encontro de Amós com Amasias revela o tema da perícope: a palavra profética e a recusa em recebê-la por parte dos líderes da nação.

Amós diz ao sacerdote que YHWH lhe ordenou, através do imperativo ?ך] presente em 15c, que fosse à terra de Israel e profetizasse. A ordem de YHWH a

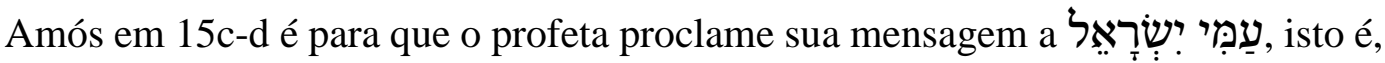
no reino do norte e não a todo o Israel (norte e sul) ${ }^{221}$. Pode-se chegar a esta conclusão através do paralelismo sinonímico em 16c-d, onde "Israel” corresponde a "Casa de Isaque".

O objetivo do arauto de YHWH foi provavelmente mostrar a Amasias que ele, Amós, era um representante de YHWH em missão no reino do norte e que rejeitar o enviado implica na rejeição daquele que o enviou. O líder nacional da religião israelita demostrou estar desalinhado com YHWH, pois enquanto YHWH envia Amós a profetizar em Israel, Amasias ordena a Amós, através do mesmo imperativo לִ em 12c, que fosse para Judá e lá profetizasse. Outro elemento importante a ser destacado em 15d é que YHWH ordena à Amós profetizar

\footnotetext{
219 JEREMIAS, J., "נָבְביא", TDMAT, p. 33.

${ }^{220}$ Cf. VERHOEF, P.A., "Profecia", in: NDITEAT, Vol 4, p. 1068. Com o tempo, provavelmente, o comportamento extático tornou-se suspeito e foi caindo em desuso.

${ }^{221}$ Cf. MCCOMISKEY, T. E., The Minor Prophets: An Exegetical and Expository Commentary Vol I, Hosea, Joel and Amos, p. 464.
} 


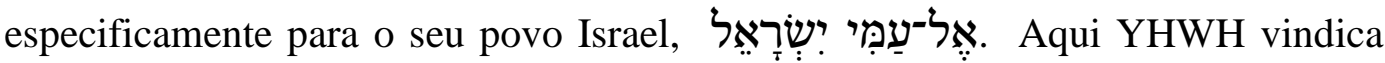
Israel como seu povo, sua propriedade, sua jurisdição (cf. Ex 19,5-6). Nas entrelinhas o texto evoca a noção de aliança pela relação de pertença: "meu povo vosso Deus.".

YHWH requer o direito de falar ao seu povo através do seu mediador; entretanto, Amasias declarou ser outro a ter plenos poderes em Betel (cf. 13b-c): ali é a palavra de Jeroboão que comanda ${ }^{222}$, e assim sendo, não há espaço para a palavra de YHWH.

Assim, as instituições que deveriam ser a legítma expressão da vontade de YHWH, tanto no nível político quanto religioso, estavam em franca rota de colisão contra YHWH, a quem deveriam representar. O palácio real e o templo já não desejavam mais ouvir a palavra de YHWH, por isso não havia mais motivos para que continuassem existindo, restando somente o seu fim.

O quadro comparativo abaixo mostra a oposição entre a palavra de YHWH e a palavra de Amasias:

\begin{tabular}{|c|c|c|}
\hline $\begin{array}{c}\text { Ordem de Amasias } \\
\text { para Amós }\end{array}$ & Oposição & $\begin{array}{c}\text { Ordem de YHWH } \\
\text { para Amós }\end{array}$ \\
\hline 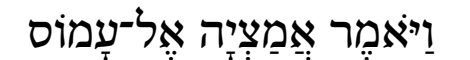 & \multirow{5}{*}{$\begin{array}{l}\text { O sacerdote } \\
\text { ordena } \\
\text { profetizar em } \\
\text { Judá ao passo } \\
\text { que YHWH } \\
\text { ordena } \\
\text { profetizar ao } \\
\text { povo de Israel }\end{array}$} & \multirow{5}{*}{ 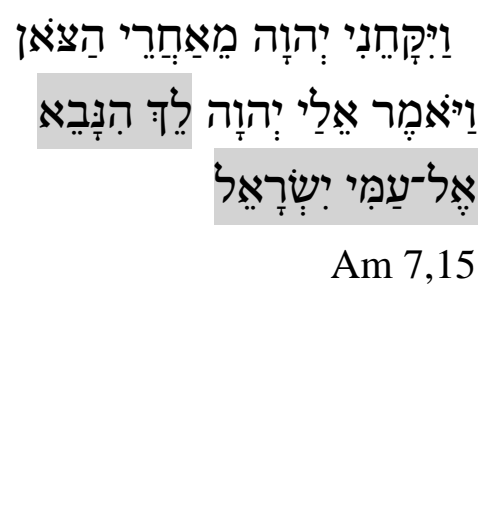 } \\
\hline 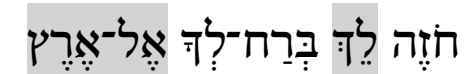 & & \\
\hline 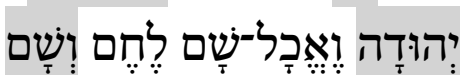 & & \\
\hline תִּנְַּבא & & \\
\hline Am 7,12 & & \\
\hline
\end{tabular}

Tabela 11

Quadro comparativo entre a palavra de YHWH em Am 7,15 e a palavra de Amasias em Am 7,12

${ }^{222}$ Cf. JEREMIAS, J., Amos: Introduzione e Commento, p. 184. 


\subsection{3.}

\section{Amós profetiza contra Amasias (vv.16-17)}

\subsubsection{1.}

\section{A justificativa de Amós para a punição de Amasias (v.16)}

Amós respondeu, nos vv.14-15, as colocações feitas por Amasias nos vv.1213, mas, nos vv.16-17, o mensageiro de YHWH deixa a defensiva e parte para a ofensiva. ${ }^{223}$ Amós pronuncia o único oráculo do livro dirigido pessoalmente a um indivíduo $^{224}$. A BH registra outras situações onde um profeta transmite um oráculo contra um indivíduo em posição de autoridade: Natã fala a Davi (cf. 2Sm 12,1ss); Elias fala a Acabe (cf. 1Rs 21,17-19); Micaías também falou a Acabe: (cf. 1Rs $22,13 \mathrm{ss})$.

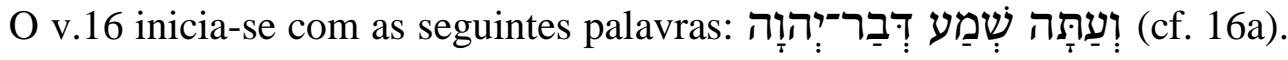
Amós convida Amasias a ouvir a palavra de YHWH, como tem convidado toda a nação ao longo da sua atividade profética (cf. Am 3,1; 4.1; 5.1). A palavra que Amós tem para comunicar não vem dele mas procede de YHWH.

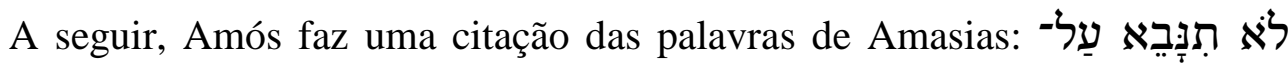

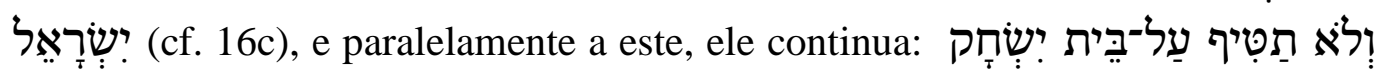
(cf. 16d). A raiz נטך pertence ao mesmo campo semântico de נבא e tem o sentido básico de gotejar, pingar, verter. ${ }^{225}$ Aqui aparece no hifil ${ }^{226}$ e tem o sentido de pregar, proclamar. As raízes נבא e נטף ocorrem juntas, em paralelismo sinonímico, em Am 7,16 e Ez 21,2.7. O verbo também significa gotejar porque pode-se referir as gotas de saliva que os profetas expelem durante suas fervorosas pregações $^{227}$. O uso da raiz נטף, não necessariamente negativo, pode indicar a forma veemente e apaixonada ${ }^{228}$ com a qual Amós, sob a comissão suprema de YHWH, entregou a sua mensagem.

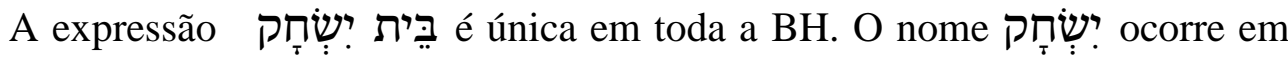
Amós apenas em Am 7,9.16 e são os únicos versículos da $\mathrm{BH}$ onde o nome do

\footnotetext{
${ }^{223}$ Cf. PAUL, S. M., Amos: A Comentary on the Book of Amos, p. 249.

${ }^{224}$ Cf. HUBB ARD, D. A., Joel e Amós: Introdução e Comentário, p. 243.

225 Cf. WILSON, M. R., "נטף", DITAT, pp. 960-961.

${ }^{226}$ A raiz נטף ocorre no hifil nas seguintes passagens da BH: Ez 21,2.7; Am 7,16; 9,13 (gotejar, destilar); Mq 2,6 (3 vezes) e Mq 2,11 (2 vezes).

${ }^{227}$ Cf. PAUL, S. M., Amos: A Comentary on the Book of Amos, p. 250.

${ }^{228}$ Cf. WOLFF, H, W., Joel and Amos: A Commentary on the Books of the Prophets Joel and Amos, p. 315 .
} 
referido patriarca designa seus descendentes, toda a nação especificamente refere-se, provavelmente, ao reino do norte. Pode-se concluir assim pelo paralelismo sinonímico que há entre $16 \mathrm{c}-\mathrm{d}$ bem como pelo fato das peregrinações feitas até Berseba (cf. Am 5,5; 8,14), no sul, que segundo as tradições bíblicas é local do nascimento do patriarca ${ }^{230}$ (cf. Gn 21,33-34) como também onde ele levantou um altar após uma teofania de YHWH (cf. Gn 26,23-25).

A citação que Amós fez das palavras de Amasias servem como acusação contra o sacerdote e tem a finalidade de provar a sua culpa ${ }^{231}$ e assim justificar ${ }^{232}$ a ameaça (cf. v.17).

Amós é acusado de conspiração por Amasias no v.10, e no v.11 Amasias cita as supostas palavras de Amós ao rei Jeroboão, mas aqui em 16c-d, é Amós quem o acusa diante de YHWH, citando as palavras do sacerdote. A acusação que pesa sobre Amasias não reside no título com o qual dirigiu-se a Amós (cf. 12b), nem mesmo nas insinuações feitas pelo sacerdote com respeito às motivações da atividade de Amós (cf. 12e-f). A acusação está na ordem de que Amós não pode mais profetizar em Israel $^{233}$. Amós, assim, incluiu diretamente Amasias e possivelmente Jeroboão na lista daqueles que pecam quando fazem calar os profetas de YHWH, ao proibirem-nos de profetizar (cf. Am 2,12; Jr 11,21; Is 30,10-12). Proibir a atividade profética equivale rejeitar a palavra de YHWH e consequentemente o próprio YHWH.

\subsubsection{2.}

O oráculo contra Amasias, sua família, sua terra e seu povo (v. 17)

O anúncio que Amós faz é precedido com a força e a autoridade da fórmula

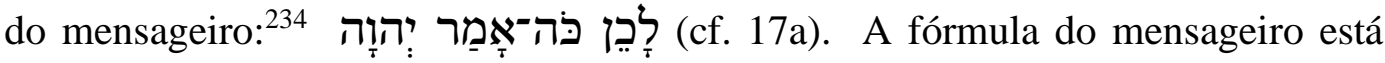
presente sobretudo na literatura profética ${ }^{235}$ da $\mathrm{BH}$, ocorrendo mais de 130 vezes

${ }^{229}$ Cf. HUBBARD, D. A., Joel e Amós: Introdução e Comentário, p.236.

${ }^{230}$ Cf. HUBBARD, D. A., Joel e Amós: Introdução e Comentário, p.236.

${ }^{231}$ Cf. SMITH, G., Comentário do Antigo Testamento: Amós, p.350.

${ }^{232}$ Cf. WOLFF, H, W., Joel and Amos: A Commentary on the Books of the Prophets Joel and Amos, p. 314.

${ }^{233}$ Cf. ANDERSEN, F. I.; FREEDMAN, D. N., Amos: A New Translation With Notes and Commentary, p.779.

${ }^{234}$ Cf. HUBBARD, D. A., Joel e Amós: Introdução e Comentário, p. 243.

${ }^{235}$ Cf. MCCOMISKEY, T, E., The Minor Prophets - Vol 1: Hosea, Joel, and Amos, p.461. 
somente no livro de Jeremias ${ }^{236}$ e 14 vezes no livro de Amós ${ }^{237}$. Esta fórmula confirma e legitima a mensagem perante o seu destinatário como também respalda o mensageiro enviado, pois este não fala por si mesmo mas em nome de YHWH que o enviou ${ }^{238}$. $\mathrm{O}$ anúncio que vem por meio desta fórmula introduz o veredito de YHWH por ser resultado de sua determinação soberana revelada ao profeta. Portanto compete a quem é dirigida a mensagem receber e aceitar as decisões e sentenças já tomadas ${ }^{239}$.

O anúncio propriamente dito sentencia Amasias, sua esposa, seus filhos, sua

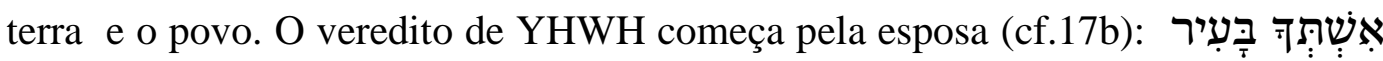

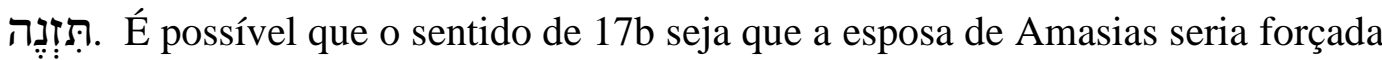
pelo exército estrangeiro. Wolff observa que, de acordo com Dt 22,23-27, se uma mulher desposada for violentada e não gritar por socorro, a mulher é considerada culpada de adultério ${ }^{240}$, o que seria uma completa vergonha e desonra para Amasias.

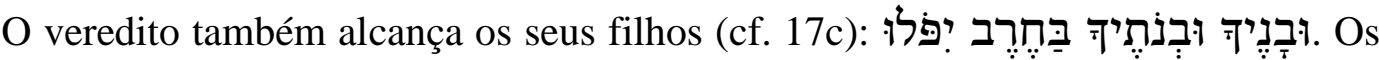
filhos de Amasias deveriam morrer transpassados pela espada, ou seja, morte violenta. O substantivo חֶרֶ ocorre 9 vezes no livro $^{241}$ e a maioria destas ocorrências estão no ciclo das visões, onde por fim a espada alcançará a todos os pecadores dentre o povo (cf Am 9,10). Aqui, como nos demais contextos, חֶרב denota a forma violenta pela qual os filhos de Amasias deveriam morrer. $\mathrm{O}$ fato dos filhos deste sacerdote serem mortos significa que Amasias ficaria sem descendentes, e, consequentemente sua memória não será perpetuada.

$\mathrm{O}$ versículo em questão não é o único na $\mathrm{BH}$ a tratar das consequências sobre os filhos de sacerdotes que rejeitam a palavra de YHWH: ao rejeitar a palavra divina, o sacerdote rejeita o conhecimento de YHWH, e consequentemente ele e seus descendentes são rejeitados (cf. Os 4,6).

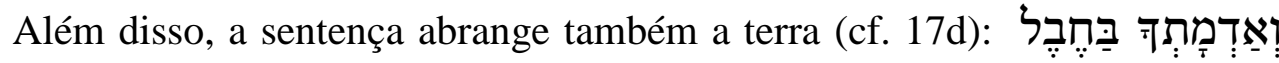

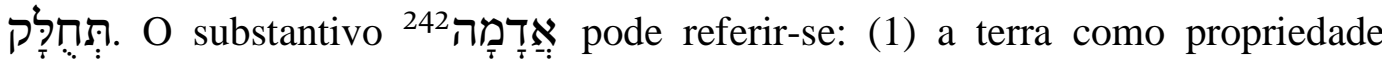

\footnotetext{
${ }^{236}$ FEINBERG, C. L., "אמֵַ", DITAT, p. 91.

237 Ocorrências da fórmula do mensageiro no livro de Amós: Am 1,1.6.9.13; 2,1.4.6; 3,11.12; 5,3.4.16; 7,11.17.

238 WAGNER, S., "אַַ", TDOT, pp. 338-339.

${ }^{239}$ BRUEGGMANN, W., Teologia do Antigo Testamento, pp. 814-815.

${ }^{240}$ Cf. WOLFF, H, W., Joel and Amos: A Commentary on the Books of the Prophets Joel and Amos, p. 315. McComiskey entende que a raiz זנה denota engajamento na atividade de prostituição. Cf. MCCOMISKEY, T, E., The Minor Prophets - Vol 1: Hosea, Joel, and Amos, p.464.

${ }^{241}$ Ocorrências de חֶּ no livro de Amós: Am 1,11; 4,10; 7,9 (2x); 7,11.17; 9,1.4.10.

${ }^{242}$ Cf. GRISSANTI, M. A., “אָדָדָה" , NDITEAT, Vol 1, p. 266.
} 
individual ; (2) o território da nação de Israel (cf. Am 5,2; 7,11); (3) todo território do mundo conhecido de então (cf. Am 3,2); (4) o solo cultivável (cf. Gn 4,3); (5) o solo onde se pisa (cf. Ex 3,5); (6) terra como sinônimo de "pó" (cf. Gn 3,19). A terra ser repartida pode expressar tanto o primeiro quanto o segundo significados ${ }^{243}$. Estrangeiros possuirão a terra que havia sido dada a Israel por YHWH (cf. Am $2,10)$.

Em seguida, o texto diz que é a vez de Amasias ouvir sobre o seu destino

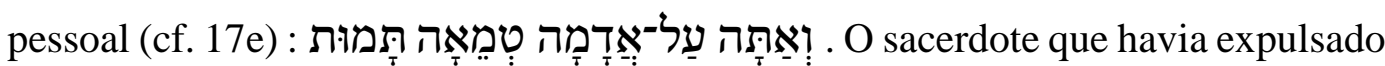
o profeta de Betel, foi condenado a ser deportado da sua terra ${ }^{244}$. Amasias foi sentenciado a morrer numa terra impura ou seja, numa terra onde os ídolos são adorados e não YHWH, pois a idolatria contamina a terra (cf. Ez 36,18.25; 37,23). Amasias, desonrado, sem descendência, está destinado a ser deportado e passar o final dos seus dias sem poder exercer o seu sacerdócio e terminar a vida no completo esquecimento. $\mathrm{O}$ texto mostra que Amasias compartilha da desgraça que também

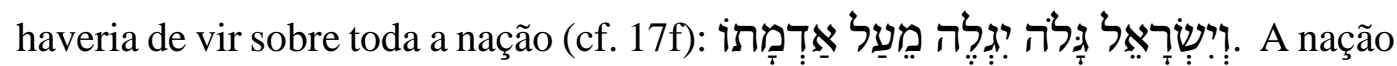
será desterrada e levada ao exílio na Assíria (cf. Am 5,5.27; 6,7).

\section{6. \\ Conclusão}

A narrativa do encontro de Amós com Amasias tem como foco central a palavra profética e seu destino: se YHWH tem direito de falar ao seu povo ou não. Assim, a narrativa põe em relevo o conflito entre a autoridade de YHWH e autoridade real e sacerdotal de Israel ${ }^{245}$.

De um lado está Amós, um pastor e colhedor de sicômoros (cf v.14-15) mas que foi chamado por YHWH e por ele comissionado para profetizar a palavra divina, sendo-lhe mediador diante do seu povo Israel, e de outro lado o sacerdote

${ }^{243}$ Cf. WOLFF, H, W; Joel and Amos: A Commentary on the Books of the Prophets Joel and Amos, p. 315 .

${ }^{244}$ Cf. SNYMAN, S. D., "The land as a leitmotiv in the book of Amos", pp. 537-538, In: Verbun et Ecclesia, vol. 26, n 2, 2005.

${ }^{245}$ Cf. BULKELEY, T., "Amos 7,1-8,3: Cohesion and Generic Dissonance”, In: ZAW, vol. 121, nº 4, p. 525 . 
Amasias, chefe do templo de Betel, o santuário nacional de Israel, representante dos interesses do rei.

A proclamação de Amós causou forte impacto em Israel, a ponto do sacerdote Amasias dizer que a terra não poderia mais conter as suas palavras (cf. Am 7,10), que pareciam transbordar no reino do norte. Amós havia proclamado contra as duas instituições basilares da nação: o templo e a monarquia (cf. Am 4,4; 5,5; 7,9). A narrativa de Am 7,10-17 mostra porque o juízo de YHWH haveria de atingir tanto a instituição religiosa quanto política (cf. Am 7,9): o santuário deveria ser domínio de YHWH passou a ser templo do rei Jeroboão ${ }^{246}$ e terminara por rejeitar a palavra de YHWH.

O sacerdote o acusou de conspiração diante do rei (cf. Am 7,10-11), ordenou que fugisse para Judá (cf. Am 7,12) e o proibiu de continuar profetizando em Betel (cf. Am 7,13). Proibido de falar por parte de Amasias, Amós não pode calar-se porque não tem vínculos institucionais, não é subordinado à monarquia, nem ao templo, mas única e exclusivamente a YHWH. Se Amós se cala, estaria reconhecendo a autoridade de Jeroboão, representada por Amasias, como sendo maior que a autoridade de $\mathrm{YHWH}$.

Por isso Amós relatou o seu chamado a Amasias (cf. Am 7,15), para que o sacerdote soubesse que um autêntico profeta não o é por escolha própria mas sim por vocação ${ }^{247}$ e que ele foi a Israel em nome de uma autoridade superior à Jeroboão. Ao contrário de muitos visionários, videntes e profetas profissionais que falavam o que os homens queriam ouvir, desde que lhe pagassem (cf. Mq 3,5), Amós falou somente o que YHWH lhe ordenou, e esta é a marca distintiva de todo autêntico arauto de YHWH: o profeta fala o que YHWH manda (cf. 2Rs 22,14). Amós profetizou o que ouviu da parte de YHWH (cf. Am 3,8) e foi em sua missão à terra de Israel como enviado e representante que fala em nome de YHWH.

O argumento de Amasias foi que o santuário de Betel era domínio de Jeroboão e ao afirmar a jurisdição de Jeroboão e proibir Amós de exercer sua missão no templo, o sacerdote incorreu nos seguintes problemas:

\footnotetext{
${ }^{246}$ NOBLE, R. N., “Amos and Amaziah in Context: Synchronic and Diachronic Approaches to Amos 7-8", The Catholic Biblical Quarterly, vol. 60, no 3, p.431.

247 Cf. TUCKER, G. M., "Prophetic Authenticity: A Form-Critical Study of Amos 7:10-17", Interpretation: A Journal of Bible and Theology, vol. 27, $\mathrm{n}^{\circ} 4$, outubro /1973, p. 434. Segundo Tucker, o propósito da narrativa de Am 7,10-17 é demostrar a autenticidade do ministério profético de Amós, para tanto a narrativa inclui as circunstâncias nas quais quais YHWH chamou o profeta.
} 
(1) Ao rejeitar a palavra de YHWH que estava na boca de Amós, Amasias rejeitou o próprio YHWH;

(2) Ao afirmar que Betel é templo do rei, o sacerdote reconhece que serve ao $\mathrm{rei}^{248}$ e não a YHWH;

(3) Ao servir de instrumento de manipulação do rei, Amasias deixa de cumprir seus verdadeiros deveres sacerdotais ${ }^{249}$. YHWH chamou Israel de "meu povo Israel", mas o chefe da religião de Israel acabara de privá-lo dos seus direitos sobre o seu povo.

A narrativa posicionada entre a terceira (cf. Am 7,7-9) e a quarta visão (cf. Am 8,1-3) nada fala sobre o que aconteceu ao profeta, se foi preso, assassinado ou se prosseguiu com sua atividade. $\mathrm{O}$ texto, no entanto, mostra que a palavra foi dada por YHWH e rejeitada pela liderança religiosa da nação. O chefe do santuário de Betel negou o direito de YHWH falar ao seu povo argumentando que aquele santuário pertencia ao rei Jeroboão. O relato mostra também as consequências desta rejeição para a nação, a começar pelo sacerdote que deveria ser o exemplo de guardião da palavra de YHWH, mas por haver desprezado a palavra divina, foi rejeitado, ele e sua família (cf. Os 4,6).

${ }^{248}$ Cf. JEREMIAS, J., Amos: Traduzione e Commento, p. 176

${ }^{249}$ Cf. VAUX, R.de., Instituições de Israel no Antigo Testamento, pp. 392-393. O sacerdote não cuidava somente das questões cultuais, mas sua competência estendia-se também para a instrução da torá, ou seja deveria ensinar o povo como deve-se obedecer a torá de YHWH. 
Am 8,11-12 e 7,10-17:

Relações quanto ao profetismo e à Palavra

4.1.

Am 8,11-12 à luz de Am 7,10-17

\subsection{1.}

\section{Am 7,10-17 e sua redação}

Os estudiosos, de modo geral, situam o tempo da atuação profética de Amós no reino do norte em torno do ano $760^{250}$ a.C. Pode-se chegar aproximadamente a esta data por dois motivos: o primeiro é que a atividade do profeta Amós ocorreu durante o reinado de Jeroboão II (782 - 753 a.C.) ${ }^{251}$ em Israel e de Uzias (767 - 749 a. C.) em Judá (cf. Am 1,1). O segundo é porque, segundo Am 1,1, Amós proclamou sua mensagem dois anos antes do terremoto. Este tremor de terra pode ser o mesmo referido no texto de Zc 14,5, onde há menção a um terremoto ocorrido nos dias do rei Uzias, evento sísmico que parece ter marcado a memória dos judaítas.

\footnotetext{
${ }^{250}$ Cf. WOLFF, H. W., Joel and Amos, p. 89. Schmidt, McComiskey e Zenger concordam com a datação de Wolff, cf. SCHMIDT, W. H., Introdução ao Antigo Testamento, p. 190. Cf MCCOMISKEY, T. E., The Minor Prophets: Hosea, Joel and Amos : An Exegetical and Expository Commentary, vol I, p. 316. Cf. ZENGER, E, O Livro dos Doze Profetas, In: Introdução ao Antigo Testamento, p. 490. Fohrer, Sicre e Abrego de Lacy situam entre 760 e 750 a.C., cf. FOHRER G., História da Religião de Israel, p. 315. Cf. SICRE, J. L., Profetismo em Israel: O profeta, os profetas, a mensagem. Cf. ABREGO DE LACY, J. M., Los Libros Profeticos, p. 51. Já Andersen e Freedmann entre 765 e 755 a.C. Cf. ANDERSEN, F. I.; FREEDMAN, D. N., Amós: a New Translation with Notes and Commentary, p. 19.

${ }^{251}$ Cf. FÜGLISTER, N., "Entusiasmado por Javé: Arauto da Palavra". In: O Antigo Testamento: Um Olhar Atento para a Sua Palavra e Mensagem, p. 168. Hubbard sugere que Jeroboão II reinou em Israel de 793 a 753 a. C. e Uzias em Judá no período de 792 a 740 a. C. cf. HUBBARD , D. A., Joel e Amós: Introdução e Comentário, pp. 101-102.
} 
Escavações arqueológicas em Hazor ${ }^{252}$ atestam a possibilidade de um terremoto ter ocorrido em meados do século VIII a.C.

Os estudiosos, porém, divergem com respeito à formação e redação do livro de Amós. Andersen e Freedman entendem que não há motivo para supor que haja partes do livro que não procedam do profeta Amós ou que sejam posteriores ao século VIII a.C, pois entendem que o livro é uma unidade altamente articulada e coerente ${ }^{253}$. Estes autores situam, então, Am 7,10-17 no tempo de Amós, no século VIII a.C.

Porém, segundo Wolff ${ }^{254}$, ainda que o processo de fixação literária do livro tenha começado no período da vida de Amós, a formação completa e final do livro foi resultado de um longo processo que dificilmente antecedeu o pós-exílio. O referido autor postulou que é possível encontrar as palavras "genuínas" de Amós, que seriam o estrato primário do livro, sobre o qual redações posteriores teriam sido adicionadas.

Wolff propõe seis camadas redacionais para o livro ${ }^{255}$ : a primeira seria constituída pelos ditos "autênticos" de Amós (capítulos 3 a 6), a segunda pelo ciclo das visões (Capítulos 7 a 9), a terceira pela “antiga escola de Amós” (Am 1,1 e Am 7:9-17). Estas três primeiras camadas pertenceriam, segundo Wolff, ao século VIII a.C. A quarta camada pertenceria à era josiânica (Am 3,14 e outros), a quinta à uma redação deuteronomista, exílica ou pós exílica, (Am 2,11-12; 3,7; 8,11-12) e a sexta pertenceria à uma redação pós-exílica (cf. Am 9,11-15). De acordo com Wolff, a "antiga escola de Amós", formada por discípulos do profeta, redigiu em um momento um pouco posterior à redação dos ditos e do ciclo das visões, talvez entre

252 Cf. DELL, K. J., "Amos and the Earthquake: Judment as Natural Disaster", p.2, In: HAGEDORN, A. C.; MEIN, A., Aspects of Amos: Exegesis and Interpretation, York Road, T\&T Clark International, 2011. Também cf. MCKENZIE, J. L., "Terremoto". In: Dicionário Bíblico, p. 924; DEVER, W. G., “A Case Study in Biblical Archaeology: The Earthquake of 760 B.C.E.”. In: Avraham Biran, Vol. 23, pp. 27-35; PERNANBUCO, M. N., Os Textos Doxológicos de Amós no Contexto do Livro, em Especial Relação com Am 1,1; 8,8 e 9,1: A Relevância da Menção do Terremoto na Mensagem do Livro, p. 92.

253 Cf. ANDERSEN, F. I.; FREEDMAN, D. N., Amos: A New Translation With Notes and Commentary, p. 144. Também cf. SMITH, G., Comentário do Antigo Testamento: Amós, p. 54. Hubbard defende que o pano de fundo histórico do ministério de Amós corresponde ao tempo da edição do livro, cf. HUBBARD, D. A., Joel e Amós: Introdução e Comentário, p. 102.

${ }^{254}$ Cf. WOLFF, H. W. , Joel and Amos, pp. 106-113. Schmidit também entende ser possível chegar a este núcleo original dos ditos de Amós. cf. SCHMIDT, W. H., Introdução ao Antigo Testamento, p. 190.

255 Cf. WOLFF, H. W., Joel and Amos, pp. 106-113. 
760 e 730 a.C, possivelmente no sul, em Judá, após a ordem de Amasias para que o profeta retornasse para a terra de Judá (cf. Am 7,12). Schmidt ${ }^{256}$, de modo geral, concorda com Wolff quanto à datação dos textos.

Jörg Jeremias observa o extremo grau de incerteza ${ }^{257}$ a respeito da possibilidade de estratos mais antigos remontarem às palavras genuínas de Amós. Mesmo assim propõe que os textos mais antigos sejam os capítulos relativos ao ciclo das visões, de 7-9, seguidos dos oráculos contra as nações 1-2 que, segundo ele, justificam as visões. Jeremias diverge de Wolff quanto à formação do livro e atribui os capítulos 3-6 à redação posterior de outros autores.

Simian-Yofre ${ }^{258}$ atribui o texto de Am 7,10-17 à redação deuteronomista devido à peculiaridade desta narrativa, seu vocabulário, a temática da palavra profética (cf. Am 2,11-12 e Am 3,6-8) e a proximidade com 1Rs 13,1-10.

Zenger $^{259}$ também acredita ser plausível esta possibilidade pois o texto, segundo ele, visa atender antes a um programa teológico que fazer um relato histórico. Zenger atribui a redação de Am 7,10-17 à época do exílio babilônico ${ }^{260}$.

Hadjiev $^{261}$ reconhece que há aproximações entre a narrativa de Am 7,10-17 e a teologia da obra historiográfica deuteronomista. Estas semelhanças, aponta o referido autor, encontra-se no vocabulário de Am 7,10-17 e textos como 2Rs 17,23 e 2Rs 25,21; como também na função do profeta descrita em Dt 18,15-19 como aplicável à Amós; além disso o tema da rejeição da palavra profética como causa para a queda de Israel $^{262}$.

No entanto, Hadjiev também aponta dessemelhanças que, segundo ele, enfraqueceriam a tese de uma possível redação deuteronomista em Am 7,10-17 e, entre seus argumentos, passa-se a citar alguns: (1) na obra historiográfica deuteronomista, profetas confrontam reis e não sacerdotes; (2) o confronto em Betel

\footnotetext{
${ }^{256}$ Cf. SCHMIDT, W. H., Introdução ao Antigo Testamento, p. 190.

${ }^{257}$ Cf. JEREMIAS, J., The Book of Amos: A Commentary, p.9. Também citado por Coimbra, cf. COIMBRA, A. S., "Debate em torno da redação e composição do livro de Amós: propostas fundamentais para a teoria da criação coletiva de Am 6,1-14".

${ }^{258}$ Cf. SIMIAN-YOFRE, H., Amos:Nuova Versione, Introduzione e Commento, p. 155.

${ }^{259}$ Cf. ZENGER, E., O Livro de Amós, In: Introdução ao Antigo Testamento, p. 486.

${ }^{260}$ Cf. ZENGER, E., O Livro de Amós, In: Introdução ao Antigo Testamento, p. 489.

${ }^{261}$ Cf. HADJIEV, T. S., The Composition and Redaction of the Book of Amos, Berlin, Walter de Gruyter, 2009.

${ }^{262}$ Cf. HADJIEV, T. S., The Composition and Redaction of the Book of Amos, p. 83.
} 
ocorreu não por causa de idolatria ou por ilegitimidade do sacerdócio (cf. 2Rs 23,4.15.15.19), mas por causa do santuário tornar-se domínio do rei Jeroboão ${ }^{263} \mathrm{e}$ portanto não haver mais espaço para YHWH e sua palavra. Hadjev conclui sugerindo que as semelhanças e dessemelhanças com a teologia deuteronomista são explicadas porque Am 7,10-17 reflete a teologia de um "proto" deuteronomista que o referido autor situou no tempo do rei Josias.

O texto de Am 7,10-17, provavelmente, é posterior à época de atuação do profeta Amós, o que parece confirmar-se pelos seguintes indícios:

(1) Há uma mudança de gênero literário bem como na pessoa que narra: de relatos de visão em $1^{\mathrm{a}}$ pessoa passa-se para narrativa em $3^{\mathrm{a}}$ pessoa.

(2) O v.10 identifica as personagens pelas suas funções. Para um israelita que viveu no reino do norte e que fosse contemporâneo de Amós, a menção relativa a Jeroboão como rei de Israel seria desnecessária.

(3) A raiz ראה é frequente no ciclo das visões e define o ato de "ver" o que YHWH mostra ao profeta (cf. Am 7,1.4.7.8; 8.1,2; 9,1). No entanto, em Am 7,12 Amasias o chama de visionário, cuja raiz é חזה. Esta raiz tem apenas mais uma ocorrência, aparecendo em Am 1,1, que é o título do livro, considerado por Wolff 264 como possivelmente posterior ao estrato básico do livro e possivelmente integrante do mesmo estrato redacional de Am 7,10-17.

(4) Am 7,10-17 tem uma impressionante semelhança com 1Rs 13,1-10. Os contextos não são os mesmos, mas há aproximações. As duas narrativas compartilham várias palavras, raízes e expressões. A tabela abaixo relaciona as duas narrativas:

\begin{tabular}{|l|l|l|}
\hline \multicolumn{1}{|c|}{ Semelhança } & \multicolumn{1}{c|}{ Am 7,10-17 } & \multicolumn{1}{c|}{ 1Rs 13,1-10 } \\
\hline $\begin{array}{l}\text { Local de origem do } \\
\text { mensageiro enviado }\end{array}$ & Tecoa, no Reino do Sul & Judá, no Reino do Sul \\
\hline $\begin{array}{l}\text { Quem envia o } \\
\text { mensageiro }\end{array}$ & YHWH & YHWH \\
\hline Local do evento narrado & Santuário de Betel & Santuário de Betel \\
\hline
\end{tabular}

${ }^{263}$ Cf. HADJIEV, T. S., The Composition and Redaction of the Book of Amos, p. 88.

${ }^{264}$ Cf. WOLFF, H. W., Joel and Amos, p. 108. 


\begin{tabular}{|l|l|l|}
\hline Presença de um rei & $\begin{array}{l}\text { Jeroboão (implícito, } \\
\text { representado por } \\
\text { Amasias) }\end{array}$ & Jeroboão \\
\hline $\begin{array}{l}\text { Identificação do } \\
\text { mensageiro }\end{array}$ & Amós & Homem de Deus \\
\hline $\begin{array}{l}\text { Mensagem contrária ao } \\
\text { receptor }\end{array}$ & $\begin{array}{l}\text { Oráculo contra Jeroboão } \\
\text { (v.11) e contra Amasias } \\
(\mathrm{v} .17)\end{array}$ & Imprecação contra o altar \\
\hline
\end{tabular}

Tabela 12

Quadro comparativo entre Am 7,10-17 e 1Rs 13,1-10

Há também uma aproximação vocabular e lexical entre os textos:

\begin{tabular}{|c|c|c|}
\hline Lexema / expressão & Amós 7 & 1 Rs 13 \\
\hline 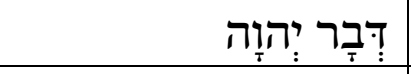 & v.16 & v. 3 \\
\hline בֵּית אִל & v. 10 & vv.1.10 \\
\hline אֶכָל לְחֶם & v.12 & vv.8.9 \\
\hline 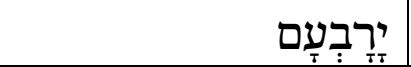 & vv.10.11 & vv.1.4 \\
\hline (יְהוּדָה & v.12 & v.1 \\
\hline שמע & $\mathrm{v} .16$ & v. 4 \\
\hline שלח & v.10 & v.4 (2x) \\
\hline דָּבָר & vv.10.16 & vv.1.2.3.4.5.9.10 \\
\hline כּהֶן & v.10 & v. 2 \\
\hline
\end{tabular}

Tabela 13

Vocabulário comum a Am 7,10-17 e 1Rs 13,1-10

(5) Contribui para a possibilidade de uma redação tardia de Am 7,10-17, o fato dos vv.11 e 17 possuírem a raiz גמעל אַדְמָתוֹ junto à expressão, que só aparece na BH em mais três versículos: 2Rs 17,23; 25,21; Jr 52,27, todos de redação 
deuteronomista ${ }^{265}$, tradição teológica que refletiu sobre as razões da perda da terra e da partida para o exílio.

A única diferença entre os textos de 2Rs 17,23 e 2Rs 25,21 é que o primeiro trata do exílio de Israel, ocorrido em 722 a.C. e o segundo do exílio de Judá em 586 a.C. O texto de Jr 52,27 é o mesmo de 2Rs 25,21.

A tabela abaixo destaca a expressão em comum nos referidos versículos:

\begin{tabular}{|c|}
\hline 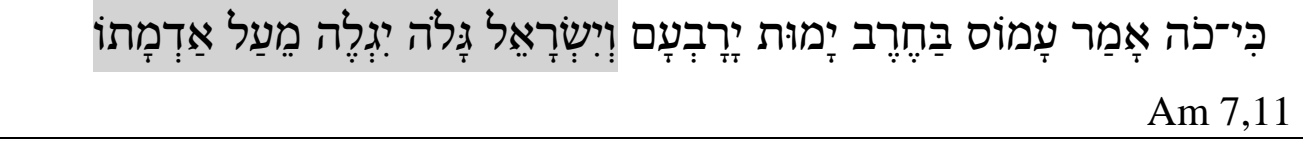 \\
\hline 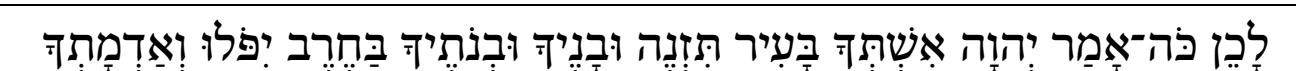 \\
\hline 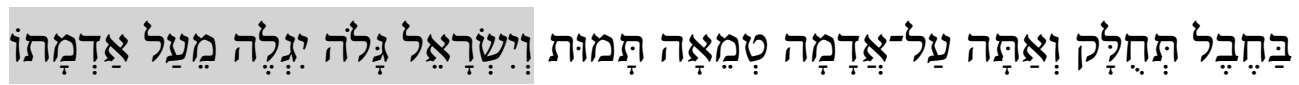 \\
\hline Am 7,17 \\
\hline \multirow{3}{*}{ 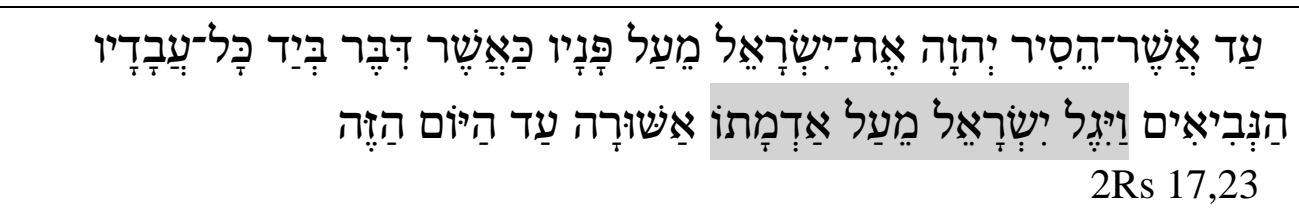 } \\
\hline \\
\hline \\
\hline \multirow{2}{*}{ 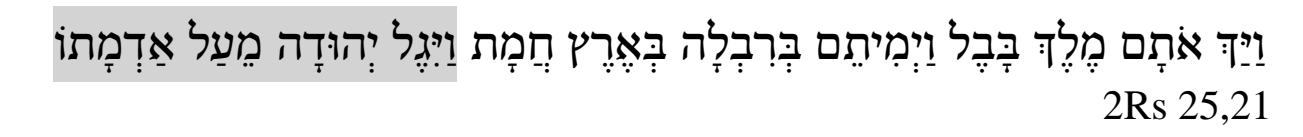 } \\
\hline \\
\hline 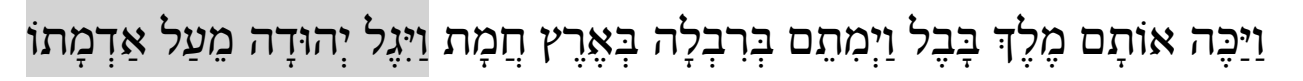 \\
\hline Jr 52,27 \\
\hline
\end{tabular}

\section{Tabela 14}

Textos da BH que compartilham da raiz גַעַל אַדְמָתוֹ junto a expressã

(6) Am 7,16-17 tem relações léxicas, terminológicas e temáticas com Jr 11,21-22. Em cada um destes textos, os versículos estão vinculados em uma relação de causa e efeito, onde o versículo que precede é a causa e o versículo que sucede é a consequência, ou seja: a rejeição da palavra profética trouxe severas consequências que alcançaram até os descendentes daqueles que rejeitaram a mensagem do profeta.

${ }^{265}$ LOHFINK, N., Balanço após a Catástrofe: A Obra Historiográfica Deuteronomística. In: SCHREINER, J. (Org.), "O Antigo Testamento: um olhar atento para a sua palavra e mensagem", p. $270-271$. 
A tabela abaixo traz a relação entre os textos:

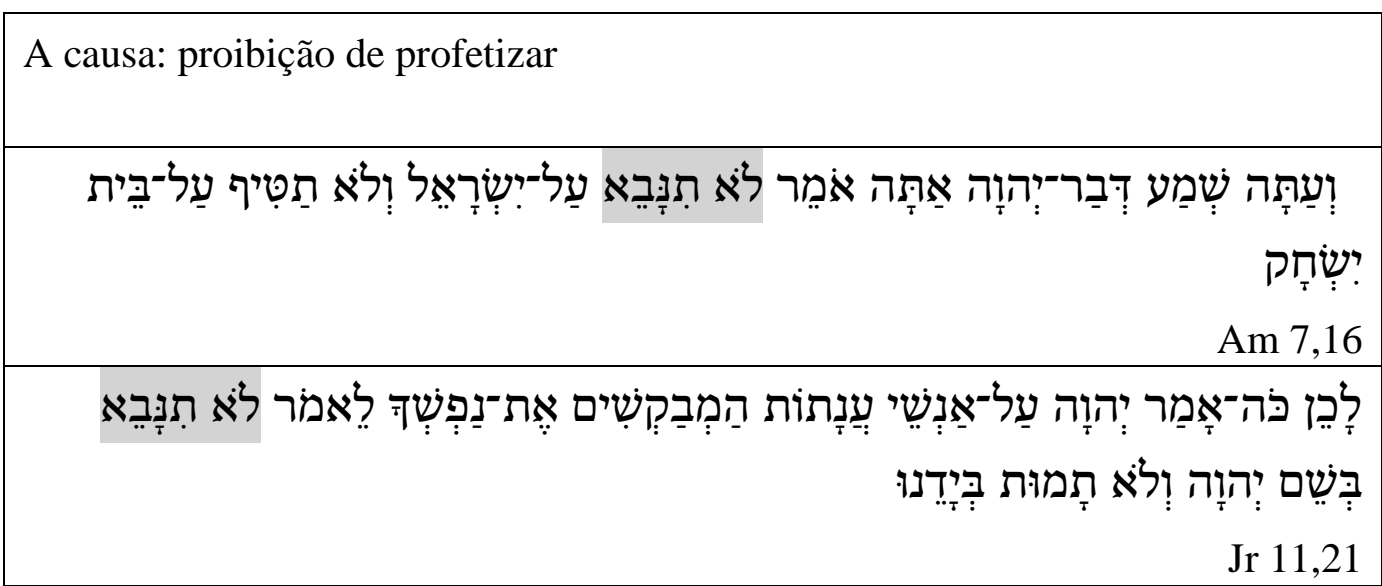

Tabela 15

Quadro comparativo das semelhanças entre Am 7,16 e Jr 11,21

A consequência: a morte pela espada e a expressão filhos e filhas é comum a ambos os textos.

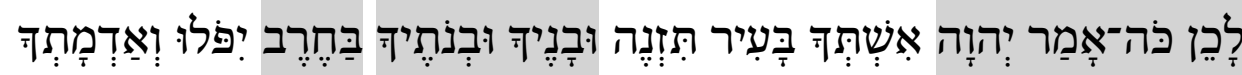

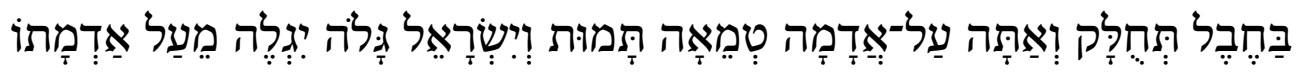

Am 7,17

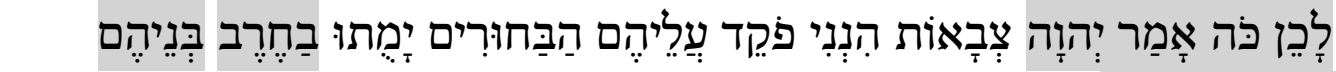

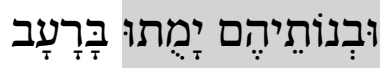

Jr 11,22

Tabela 16

Quadro comparativo das semelhanças entre Am 7,17 e Jr 11,22

Pelo exposto, é bem provável que Am 7,10-17 não faça parte do estrato redacional do ciclo das visões, sendo inserido entre a $3^{\mathrm{a}}$ e a $4^{\mathrm{a}}$ visão em tempo posterior, possivelmente no período neobabilônico ${ }^{266}$, devido à aproximação com outros textos que são parte da obra historiográfica deuteronomista e de sua escola teológica. O propósito teológico da narrativa possivelmente é explicar que Israel e Judá chegaram ao fim devido a rejeição da palavra profética.

266 Cf. RÖMER, T., A Chamada História Deuteronomista: Introdução Sociológica, Histórica e Literária, pp. 133, 152-153. 


\subsection{2.}

\section{Am 8,11-12 e sua redação}

Wolff admite a possibilidade, apesar de sua incerteza, de Am 8,11-12 pertencer à redação deuteronomista ${ }^{267}$ pelo interesse que esta tem pelo fenômeno da profecia, o que pode ser verificado no livro de Amós em textos como Am 2,1112 e Am 3,6b.7.8b.

Zenger $^{268}$ também sugere que Am 8,11-12 seja redação posterior, possivelmente, do tempo do exílio. Schart ${ }^{269}$ também aponta para possibilidade deste texto ser redação deuteronomista por causa da relação entre a palavra de YHWH e pão estabelecida em Dt 8,3. Römer alista Dt 8 entre os textos da edição deuteronomista exílica do período neobabilônico ${ }^{270}$.

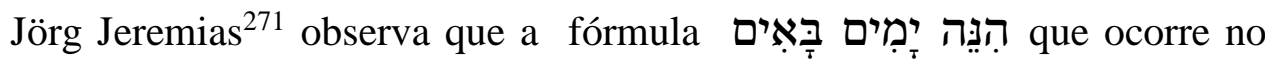
início de Am 8,11 é típica do livro de Jeremias ${ }^{272}$ no qual ocorre quatorze vezes. À parte do livro de Jeremias, a referida expressão ocorre três vezes em Amós (cf. Am $4,2 ; 8,11 ; 9,13)$ e também em $1 \mathrm{Sm} 2,31 ; 2 \mathrm{Rs} 20,17$ e Is $39,6$.

Jörg Jeremias também faz as seguintes observações ${ }^{273}$ :

(1) Am 8,11-12 pressupõe Am 7,10-17, e Am 2,11-12. A pressuposição dá-se pelo fato de Am 8,11-12 ser a consequência de Am 7,10-17.

(2) Am 8,11-12 pressupõe também as pragas da fome, da sede, da peste e da espada enviadas por YHWH (cf. Am 4,6-11), onde Am 4,11 faz referência ao remanescente do exílio. A fome e a sede previstas em Am 8,11-12 são de natureza espiritual: YHWH ameaça retirar a sua palavra.

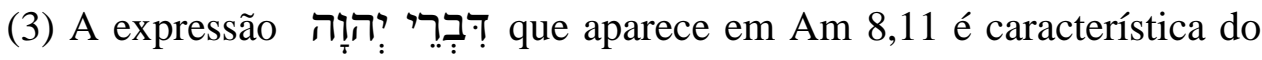
período exílico.

(4) Am 8,11-12 foi dirigido àqueles que sobreviveram à destruição da cidade de Jerusalém em 586 a.C. O propósito desta redação, provavelmente, é alertar que

\footnotetext{
${ }^{267}$ Cf. WOLFF, H. W., Joel and Amos, p. 113.

${ }^{268}$ Cf. ZENGER, E., O Livro de Amós, In: Introdução ao Antigo Testamento, p. 489.

${ }^{269}$ Cf. SCHART, A., Die Entstehung des Zwölfprophetenbuchs, 1998. p. 92.

${ }^{270}$ Cf. RÖMER, T., A Chamada História Deuteronomista: Introdução Sociológica, Histórica e Literária, p. 131.

271 JEREMIAS, J., Amós: Introduzione e Commento, p. 196.

${ }^{272}$ Cf. Jr. 7,32; 9,24; 16,14; 19,6; 23,5.7; 30,3; 31,27.31; 33,14; 48,12; 49,2; 51,47.52.

273 JEREMIAS, J., Amós: Introduzione e Commento, p. 196.
} 
aquela geração não estava salva porque havia sobrevivido a toda aquela devastação. Os exilados deveriam considerar seriamente a palavra de YHWH, pela conversão, retornando à fé em YHWH, antes que YHWH retirasse a sua palavra do meio do povo.

Rösel também vê indícios de redação posterior em Am 8,11-12. O referido

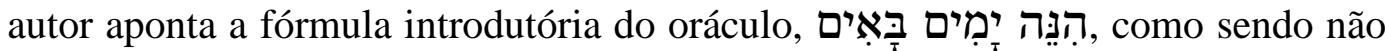
característica de Amós ${ }^{274}$, como também a espiritualização da fome ${ }^{275}$. Para Rösel, a chave para entender o limite geográfico demarcado em Am 8,12 é saber se Am 8,11 pertence ao estrato primário do livro ou não. Como ele entende que Am 8,11 é redação posterior, possivelmente exílica, no parecer dele Am 8,12 tem limite geográfico mais amplo ${ }^{276}$ que Israel e Judá, referindo-se então à busca desorientada no exílio.

Hadjiev comenta que a descrição de uma procura inútil pela palavra de YHWH (cf. Am 8,11-12) encaixa bem em um período exílico. O tema do desaparecimento da palavra de YHWH surge também em S1 74,9, Lm 2,9 e Ez 7,26, textos geralmente datados do período exílico. Am 8,11-12 seria uma atualização de Am 4,6-8 mas à luz de Dt 8,3. ${ }^{277}$

É mesmo provável que o redator de Am 8,11-12 tenha escrito este texto tendo Dt 8,3 diante de si, pois a associação entre pão e palavra de YHWH denota uma reflexão teológica mais tardia em relação ao estrato primário do livro de Amós.

Assim, Am 8,11-12, possivelmente, pertence à redação deuteronomista ${ }^{278}$ do período neobabilônico escrito com o propósito de alertar os exilados quanto à necessidade e importância de obediência à palavra e a conversão à YHWH.

\footnotetext{
${ }^{274}$ Cf. RÖSEL, H. N., "Kleine Studien zur Entwicklung des Amosbushes", Vetus Testamentum, Leiden: E. J. Bill, v.43, p.99.

${ }^{275}$ Cf. RÖSEL, H. N., "Kleine Studien zur Entwicklung des Amosbushes", Vetus Testamentum, Leiden: E. J. Bill, v.43, pp.99-100.

276 Cf. RÖSEL, H. N., "Kleine Studien zur Entwicklung des Amosbushes", Vetus Testamentum, Leiden: E. J. Bill, v.43, p.100.

${ }^{277}$ Cf. HADJIEV, T. S., The Composition and Redaction of the Book of Amos, p. 106.

${ }^{278}$ A respeito de uma revisão deuteronomista do livro de Amós, Schmid citando Schmidt afirma: “... também o livro de Amós foi aparentemente, mais tarde, submetido a uma, se não abrangente, pelo menos marcante revisão deuteronomista... O livro de Amós oferecia-se a uma revisão em perspectiva “deuteronomista' porque Amós - à semelhança de Jeremias na catástrofe do reino do sul - era o profeta que atuava ao tempo do reino do norte.”. Cf. SCHMID, K., História da Literatura do Antigo Testamento, p. 125.
} 


\subsection{3.}

\section{Amós 8,11-12 e Am 7,10-17: cronologia relativa}

Os dois textos relacionam-se de forma contrastante: em Am 7,10-17 há rejeição da palavra de YHWH pois o profeta foi proibido de profetizá-la; porém, em Am 8,11-12 é anunciado o tempo em que haverá fome de ouvir a palavra divina; esta, contudo, não será mais encontrada. Am 7,10-17 mostra que a liderança religiosa rejeitou a palavra de YHWH (cf. Am 7,13). Esta rejeição tornou-se a causa do juízo anunciado em Am 8,11-12: o repúdio à palavra de YHWH resultaria na retirada desta palavra. Portanto, os textos de Am 7,10-17 e Am 8,11-12 vinculamse por uma relação de causa e efeito, respectivamente.

Os dois textos também encontram-se relacionados pela repetição lexical: a raiz שלח ocorre em Am 7,10 onde Amasias envia mensagem ao rei Jeroboão acusando Amós de conspiração; em Am 8,11 é a vez de YHWH “enviar” a fome da palavra divina.

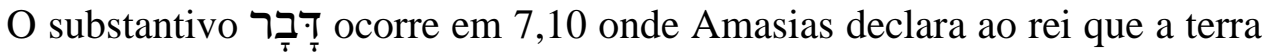
não pode mais suportar as "palavras" do profeta; em 7,16 a "palavra" de YHWH é dirigida a Amasias; em 8,11, é anunciada uma fome desta mesma "palavra" e em 8,12 é dito que a "palavra" não será mais encontrada.

Outro substantivo, אֶרץ, aparece em 7,10 onde é dito que a "terra" não pode suportar as palavras do profeta, e em 7,12 o profeta é ordenado a profetizar em outro lugar, na "terra" de Judá. Já em 8,11 YHWH envia fome da palavra sobre a "terra" de Israel. A terra que antes "transbordava" as palavras de YHWH por meio do seu profeta, agora vai amargar com a escassez destas palavras.

Outro substantivo que ocorre em 7,12 é לֶחם. Havia profetas que exerciam seus ministérios pelo "pão", ou seja, para a sua subsistência. Amasias ordenou que Amós fosse profetizar em Judá e lá comer o seu "pão". Am 8,11 prediz a fome que não será de "pão", mas da palavra.

A tabela a seguir auxilia na visualização do que foi dito acima: 


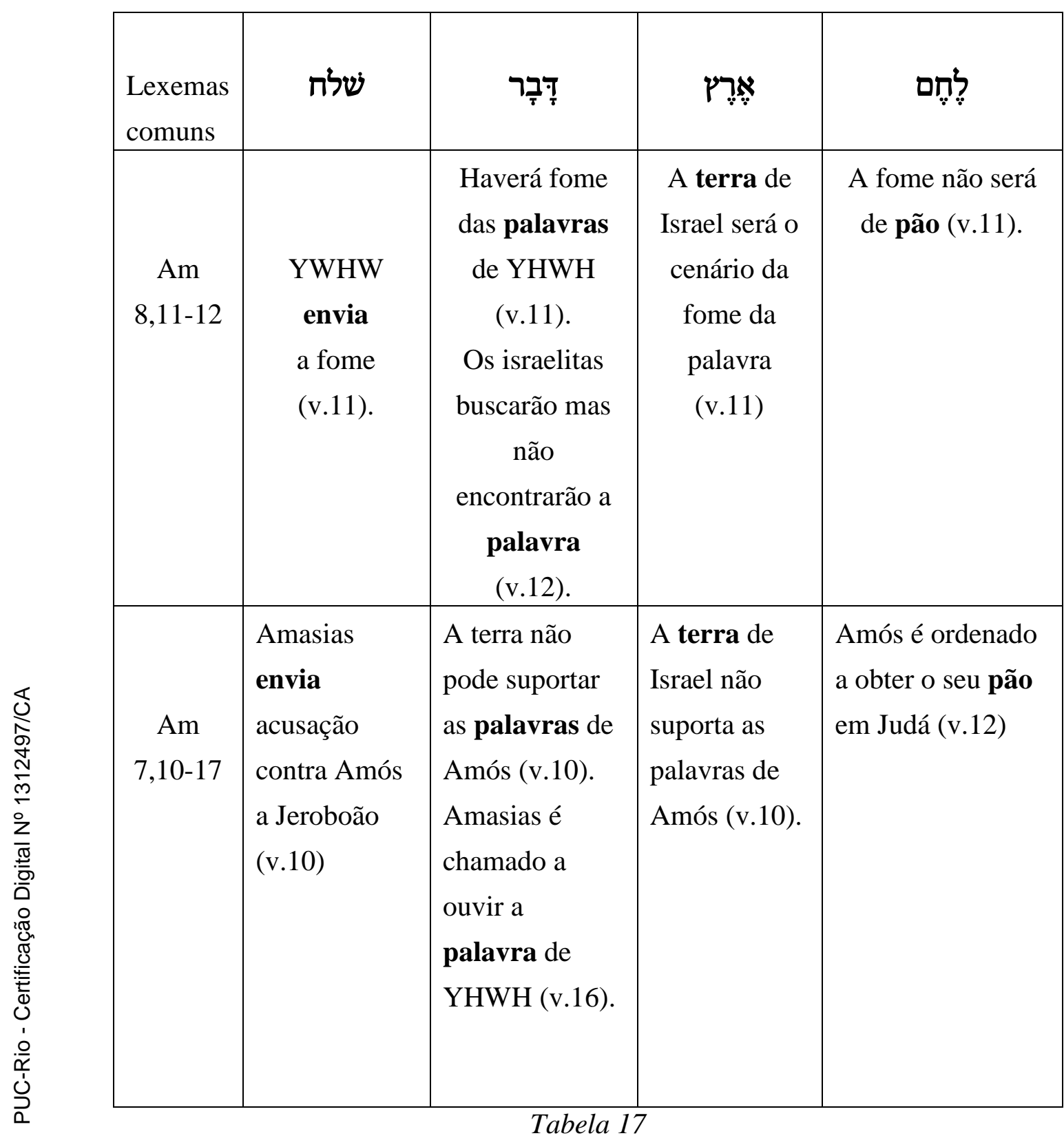

Vocabulário comum a Am 8,11-12 e Am 7,10-17

Am 8,11-12 parece fazer alusão às três personagens de Am 7,10-17: Jeroboão, Amasias e Amós. Conforme constatou Schart, pode-se verificar isto através da observação das três consoantes do substantivo רָָּב que aparecem

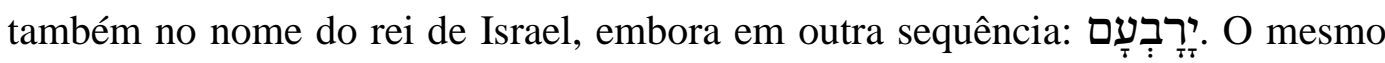
ocorre com o substantivo צָָָָא: são as mesmas consoantes que iniciam o nome do

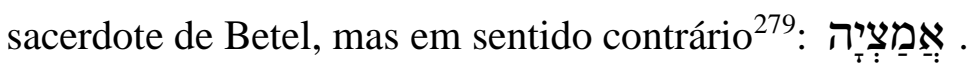

\footnotetext{
${ }^{279}$ Cf. SCHART, A., Die Entstehung des Zwölfprophetenbuchs. Neubearbeitungen von Amos im Rahmen schriftenübergreifender Redaktionprozesse. Berlin / New York: W. de Gruyter, 1998, p. 91.
} 
As consoantes de צָָ צָ aparecem, ainda que em outra sequência, em 8,12: ימצאו. Assim o redator do texto, provavelmente, associou a praga da fome e da sede da palavra aos nomes da liderança política, Jeroboão, e religiosa da nação, Amasias. Neste panorama também é possível que ?ְִׁׁ faça referência a Amós, עָמוֹס o que pode ser verificado invertendo-se a sequência das consoantes do nome do profeta e substituir o shin pelo samech para constatar a semelhança fonética ${ }^{280}$. Desta semelhança sonora entre o nome do profeta e o verbo ouvir depreende-se que a nação teve a oportunidade de ouvir a palavra de YHWH pelo ministério profético de Amós, mas não a acolheu.

O que foi dito acima pode ser resumido na tabela abaixo:

\begin{tabular}{|c|c|c|}
\hline Am 8,11-12 & \multirow{4}{*}{$\begin{array}{c}\text { Alusão } \\
\text { a... }\end{array}$} & Am 7,10-17 \\
\hline רָרָב & & זירָבְעָם \\
\hline צָמָא & & אַמַצְיָה \\
\hline לִשְממעע & & עָמוֹס \\
\hline
\end{tabular}

Tabela 18

Relação entre vocábulos de Am 8,11-12 e Am 7,10-17

As observações acima conduzem à conclusão, com respeito à cronologia relativa, que Am 8,11-12 foi redigido, provavelmente, após Am 7,10-17 porque se assim não fosse as relações estabelecidas entre fome/Jeroboão, sede/Amasias/encontrar, ouvir/Amós ${ }^{281}$ não fariam sentido.

\section{2.}

\section{A função profética e a palavra}

A imagem do que é ser um profeta, qual é a sua missão e as consequências da rejeição de sua mensagem é definida no livro de Amós por meio dos seguintes

${ }^{280}$ Cf. SCHART, A., Die Entstehung des Zwölfprophetenbuchs. Neubearbeitungen von Amos im Rahmen schriftenübergreifender Redaktionprozesse. Berlin / New York: W. de Gruyter, 1998, p. 91.

${ }^{281}$ Cf. SCHART, A., Die Entstehung des Zwölfprophetenbuchs. 1998. p. 92. 
textos: Am 2,12; Am 3,8; Am 7,12.13.15.16. Estes versículos possuem em comum a raiz נבא que define a ação de profetizar.

Em Am 2,12 YHWH queixa-se que Israel proíbe os profetas de profetizar. Os versículos seguintes, Am 2,13-16, tratam das consequências desta proibição. O mesmo acontece em Am 7,13, onde Amasias proíbe Amós de profetizar e as consequências são descritas em Am 7,17. Em Am 3,8 há a pergunta retórica: se YHWH falou quem deixará de profetizar? Em Am 7,15 Amós ouviu a comissão da palavra de YHWH dizendo-lhe: 'vai e profetiza!’.

A tabela abaixo relaciona os referidos versículos de Amós:

\begin{tabular}{|c|c|c|}
\hline Am 2,12 & “...não profetizeis!” & 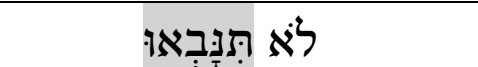 \\
\hline Am 7,12 & “...e lá profetiza;” & וֹשׁשם תתנּבא \\
\hline Am 7,13 & “...não podes mais profetizar" & לאיא-תוֹסִיף עוֹד לְהִנְּבַא \\
\hline Am 3,8 & $\begin{array}{c}\text { "...o Senhor Deus falou, quem não } \\
\text { profetizará?" }\end{array}$ & 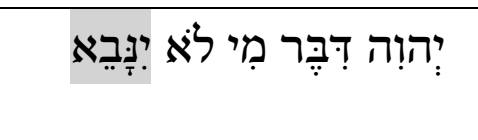 \\
\hline Am 7,15 & $\begin{array}{c}\text { "...YHWH disse-me: vai! profetiza } \\
\text { ao meu povo Israel" }\end{array}$ & 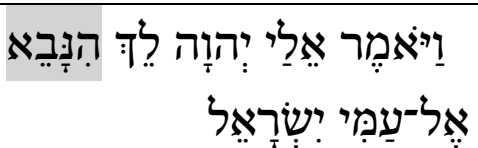 \\
\hline Am 7,16 & $\begin{array}{c}\text { "Tu dizes: Não profetizes contra } \\
\text { Israel..." }\end{array}$ & 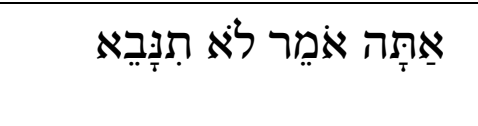 \\
\hline
\end{tabular}

\section{Tabela 19}

Relação de versículos do livro de Amós com a ocorrência da raiz נבא

YHWH comunica-se com o seu povo por meio dos seus profetas. Em diferentes períodos da história do seu povo YHWH levanta profetas e lhes outorga uma missão. Estes mediadores da palavra divina são, muitas vezes, enviados por YHWH em situações emergenciais de crise para falar às autoridades do povo, notadamente aos reis ou aos seus representantes. Assim a BH, a título de exemplo, registra Elias sendo enviado ao rei Acabe (cf. 1Rs 18,1.17; 21,17); Micaías também 
foi enviado ao rei Acabe (cf. 22,8); Isaías enviado ao rei Acaz (cf. Is 7,3-17) e ao rei Ezequias (cf. Is 37,1-7), e Amós, enviado ao reino de norte (cf. Am 7,15), tem um encontro com Amasias, chefe da religião nacional e representante do rei Jeroboão.

Estes servos de YHWH, especialmente despertados pela vocação que receberam, possuem uma consciência missional que lhes toma completamente, pois ao receber a palavra, o profeta precisa proclamá-la (cf. Am 7,15). Os profetas não relacionam-se com a palavra de forma neutra ou objetiva; pelo contrário, quando YHWH dirige-lhes a palavra, esta os "assalta" e os "possui" pois os profetas dela se apropriam e deixam-se preencher pela palavra que receberam ${ }^{282}$.

Os profetas falam porque foram compelidos por YHWH e por isso ninguém pode silenciá-los ${ }^{283}$. Eles têm a consciência de que estão sob suprema autoridade e por isso entregam a mensagem de YHWH aos reis, aos sacerdotes e a qualquer um a quem YHWH lhes enviar. Estes arautos divinos não medem esforços e não pesam as consequências das palavras que como mensageiros devem anunciar, pois o senso da missão é que os motiva.

Os profetas têm ouvidos abertos para ouvir a voz de YHWH (cf. Is 50,4-5) e ao ouvi-la têm o encargo de profetizá-la (cf. Am 3,8). Estes homens estão muito próximos de YHWH (cf. 1Rs 18,15; 2Rs 3,14), vivem em seu conselho (cf. Jr 23,18) e por isso YHWH revela-lhes os seus segredos e lhes anuncia o que há de fazer (cf. Am 3,7). Assim como a instrução está para o sacerdote e o conselho para o sábio, a palavra de YHWH pertence ao profeta (cf. Jr 18,18).

A palavra de YHWH é a vida da nação (cf. Dt 32,47) mas se a nação abandona a palavra, perde os alicerces da sua existência ${ }^{284}$ e é por isso que existem estes arautos divinos que, como mediadores entre YHWH e a nação, trazem a palavra viva para o povo a fim de admoestá-lo com a finalidade pragmática de trazêlo de volta a YHWH. Os profetas sabem que a subsistência de Israel depende da

\footnotetext{
${ }^{282}$ Cf. RAD, G. V., Teologia do Antigo Testamento, p. 520.

${ }^{283}$ Cf. BRUEGGMANN, W., Teologia do Antigo Testamento, p. 806.

${ }^{284}$ Cf. WESTERMANN, C.; Os Fundamentos da Teologia do Antigo Testamento, São Paulo, Ed. Academia Cristã, 2011, p. 144.
} 
palavra de YHWH e que o povo depende desta palavra até os níveis mais vitais de sua existência ${ }^{285}$.

É sinal do favor divino que a palavra esteja acessível ao povo, bem perto de cada um (cf. Dt 30,11-14) e o profeta como dom de YHWH ao povo é o seu portavoz (cf. Dt 18,15). A palavra de YHWH na boca dos profetas é a atualização, a cada geração e época, das palavras de YHWH, reveladas na Torá que é o fundamento da profecia. Portanto, sob prisma canônico, os profetas são legítimos herdeiros da tradição mosaica. Assim os profetas erguem a voz contra as violações aos preceitos da Torá, como o fez Amós (cf. Am 5,10-13.14.15.24; 8, 4-7).

A teologia deuteronomista estabeleceu em Dt 18,15-19 a base para a relação entre a recusa entre ouvir as palavras de YHWH por intermédio dos profetas e o exílio $^{286}$. YHWH promete levantar um profeta semelhante a Moisés (cf. Dt 18,15) para ser mediador entre YHWH e o povo (cf. Dt 18,16); YHWH confiará sua palavra a este profeta (cf. Dt 15,18) e este profeta deve ser ouvido pelo povo, caso contrário este povo será punido (cf. 18,19). Sob a perspectiva canônica, Moisés é o modelo, verdadeiro paradigma para a teologia deuteronomista. Semelhantes a Moisés, servo de YHWH, outros servos haveriam de ser levantados para serem mediadores da palavra divina.

YHWH envia os seus profetas, para falar a sua palavra ao povo; porém se o povo não os ouve é atingido pelo juízo (cf. Jr 29,17-19; 35,13-17). Amós foi levantado e comissionado por YHWH para falar a sua mensagem ao reino do norte nos dias de Jeroboão II. Porém, Amasias, a mais alta autoridade religiosa da nação, rejeitou a palavra de YHWH. Quando uma nação rejeita a palavra de YHWH está rejeitando o próprio YHWH, e por isso tal nação termina por ser rejeitada também. O reino do norte recebeu o juízo do exílio na Assíria por não ouvir as palavras dos profetas de YHWH (cf. II Rs 17,22-23), e o mesmo aconteceu com o reino do sul, ao ser exilado na Babilônia (cf. II Rs 17,10-13; 24:1-3).

Am 8,11-12 trata do anúncio de dias onde YHWH haveria de silenciar-se. O silêncio de YHWH é presságio da sua ira e seu desamparo, como foi o caso de

\footnotetext{
${ }^{285}$ RAD, G. V., Teologia do Antigo Testamento, pp. 527-528.

${ }^{286}$ Cf. RÜTERSWÖRDEN, U., "שמע", TDOT, p. 265.
} 
Saul (cf. 1Sm 14,37; 28.6.15-16). YHWH pune seu povo quando silencia-se, tornando rara a sua palavra em algumas ocasiões (cf. 1Sm 3,1).

O profeta, como mediador, não apenas fala de YHWH ao povo mas também fala a YHWH pelo povo, pois a intercessão integra a função do profeta.

Assim fez o profeta Amós: intercedeu a Deus pelo povo, suplicando pelo perdão nas duas primeiras visões (cf. Am 7,1-6) e YHWH perdoou. Porém nas duas visões seguintes, YHWH já não quer mais perdoar, pois decretou o fim da nação e consequentemente já não há intercessão do profeta, sendo poucas as suas palavras (cf. Am 7,7-8; 8,1-2). Quando é relatada a quinta visão, não há diálogo algum, mas apenas a ordem para a destruição do santuário. Há o completo silêncio do profeta (cf. Am 9,1). O silêncio passa a ser de ambos os lados: o profeta não falará mais ao povo em nome de YHWH, nem o profeta falará a YHWH pelo povo. Deus não mais ouvirá, nem perdoará: em outras palavras, o fim chegou para a nação. Qualquer esforço humano, qualquer ação destinada a mudar a situação revelar-se-á inútil ${ }^{287}$.

A palavra divina é como a luz do sol que brilha primeiro no profeta para então iluminar a vida do povo, mas, quando YHWH retira esta luz, os profetas nada mais podem saber, nem os videntes (cf. Mq 3,6-7). Possivelmente com a metáfora do sol em vista, os redatores de Am 8,9 falaram de um eclipse solar no qual o sol iria pôr-se ao meio dia e a terra de Israel seria coberta de trevas em pleno dia claro, e sem esta luz da palavra inevitavelmente o seu povo tropeçará porque andará nas trevas.

Dentro da mesma seção de Am 8,9, em Am 8,11, é anunciado que a palavra seria ocultada do povo através da metáfora da fome. Muito provavelmente esta metáfora foi utilizada tendo em vista Dt 8,3, no qual YHWH afirma ter deixado o seu povo com fome para que este aprendesse uma lição áurea: não só de pão o homem vive, mas de toda a palavra de YHWH o homem deve viver.

O tema da palavra de YHWH como alimento surge em Dt 8,3 e reaparece em outros textos proféticos, além de Am 8,11: o profeta Jeremias afirma ter comido as palavras de YHWH no momento em que as encontrou (cf. Jr 15,16); Ezequiel recebeu a ordem de YHWH para comer o rolo escrito por dentro e por fora para

287 Cf. BOVATI, P.; MEYNET, R., Le Livre du Prophète Amos, pp. 333-334. 
somente então profetizar ao povo (cf. Ez 2,8 - 3,3). Portanto, se YHWH retira o alimento da palavra, o povo progressivamente morrerá, pois a palavra sustenta o espírito da nação assim como o alimento sustenta a vida física.

Os olhos do povo são os profetas, porque vêem na dimensão divina, mas se estes olhos são fechados, ninguém mais pode ver, e por isso o povo fica vagueando sem alcançar o objetivo (cf. Am 8,12), pois perdeu a direção (cf. Is 29,10) o que inevitavelmente fará o povo tropeçar ao meio dia como se fosse em plena (cf. Is 59,10). Quando, finalmente, deparar-se-ão com a cruel realidade de que o dom lhes foi retirado, pois já não há mais profetas (cf. S1 74,9).

Am 8,11-12 trata da extinção do profetismo no reino de norte ${ }^{288}$ anúncio que pode ter sido utilizado também como alerta e ensino para o reino do sul. Se a profecia acompanhou a história de Israel como um sinal da presença do Deus vivo no meio de seu povo, o fim da profecia é equivalente ao final da história de Israel $^{289}$. O fim do profetismo foi um juízo que precede e integra o juízo que culmina no cativeiro assírio no reino do norte. Sem a palavra de YHWH para orientá-lo, o povo perde a direção e não há como retornar a YHWH, não há como arrepender-se. Am 8,12 afirma que os israelitas buscarão a palavra em todas as direções mas jamais irão encontrá-la novamente, pois não haverá mais profetas (cf. Sl 74,9; Lm 2,9; Ez $7,26)$.

A presença dos profetas é sinal que YHWH quer comunicar-se e favorecer o seu povo se este der ouvidos à sua palavra por meio dos seus mensageiros. Enquanto a palavra divina estiver presente em meio ao povo, através dos profetas, há esperança de dias melhores; no entanto, se a palavra for retirada é sinal que YHWH não quer mais falar, nem favorecer o seu povo. E se YHWH cessar de falar cessará também a esperança de qualquer futuro pois até as virgens e os jovens, símbolos de vigor e perpetuidade, perderão as forças e desfalecerão (cf. Am 8,13).

O silêncio de YHWH, manifesto na ausência de profetas, resulta na queda irreversível do povo (cf. Am 5,2; Am 8,14). É sinal de juízo condenatório decretado do qual ninguém poderá escapar (cf. Am 9,1-4).

\footnotetext{
${ }^{288}$ Cf. FÜGLISTER, N., Entusiasmado por Javé: Arauto da Palavra, in: SCHREINER, J. (Org.), "O Antigo Testamento: um olhar atento para a sua mensagem", p. 172.

${ }^{289}$ Cf. BOVATI, P.; MEYNET, R., Le Livre du Prophète Amos, p. 336.
} 


\section{5 \\ Conclusão}

O estudo do contexto literário maior de Am 8,11-12, que é o ciclo das visões, permitiu compreender a progressão na qual o povo seria atingido pelo juízo divino. Se nos dois primeiros pares de visão (cf. Am 7,1-3 e Am 7,4-6) YHWH perdoa o povo devido à intercessão do profeta, nos dois pares seguintes (cf. Am 7,7-9 e Am 8,1-3) a disposição divina para perdoar havia terminado, não havendo mais intercessão alguma do profeta. Já a quinta visão (cf. Am 9,1-4) descreve a destruição do santuário e da nação. O estudo da perícope de Am 8,9-14 e sua forma revelou que Am 8,11-12 ocupa posição central na estrutura do texto, anunciando um juízo que atingiria o povo espiritualmente.

A análise da forma de Am 8,11-12 mostrou a relação de causa e efeito entre os vv.11-12, onde no v.11 YHWH anuncia a ação de enviar a fome das suas palavras e no v.12 encontramos o resultado da ação divina: uma busca desorientada e infrutífera pela sua palavra. A análise semântica mostrou que através da metáfora do envio da fome, YHWH anuncia a chegada de um tempo no qual as suas palavras não seriam mais ouvidas, pois deixariam de ser proclamadas. Sem a palavra divina para orientá-los, os israelitas haveriam de buscá-la nos mais diversos locais, sem, contudo, encontrá-la. O uso da imagem do pão e da água retrata bem a necessidade vital da palavra para o povo de YHWH. A ausência da palavra resultaria inevitavelmente no fim da nação.

Quando YHWH envia a fome de ouvir suas palavras, YHWH está trazendo juízo sobre seu povo. O juízo anunciado sobre o povo, inicia, então, com o silencio divino. A ausência da palavra divina faz parte da punição recebida por Israel, pois integra, antecede e culmina no cativeiro assírio.

O estudo da narrativa presente em Am 7,10-17, realizado no capítulo três, iniciou-se pelo seu contexto imediato. Verificou-se que há conexões temáticas e linguísticas da narrativa tanto com a visão precedente (cf. Am 7,7-9) como com a visão subsequente (cf. Am 8,1-3) e serviu para compreender o porquê esta narrativa 
está localizada entre a terceira e a quarta visão: o propósito Am 7,10-17 é explicar a terceira visão e justificar a quarta visão, ou seja, o porquê do fim da nação.

A análise da forma permitiu chegar à estrutura do texto que tem como centro a palavra profética. Por trás do embate de Amós e Amasias, estava a tensão entre a autoridade de YHWH, representada por Amós, e a autoridade do rei Jeroboão, representada por Amasias. Quando Amasias, líder da religião nacional, proibiu a Amós de continuar profetizando no santuário de Betel, o sacerdote argumentou que o santuário era jurisdição do rei. Com efeito, o sacerdote negou a YHWH o direito de falar ao seu povo por intermédio do seu arauto Amós.

A análise semântica proporcionou uma compreensão maior a respeito do profetismo, os termos que designam a atividade profética, a vocação pessoal de Amós e a missão que recebeu de YHWH. Amós não é um profeta profissional nem está vinculado à instituição monárquica, religiosa ou a alguma agremiação profética, por isso Amós não se calou diante de Amasias, porque estava representando alguém maior que Jeroboão.

O capítulo quatro tratou de estudar as relações entre Am 8,11-12 e Am 7,1017, a precedência entre eles e possíveis relações literárias. Não há concordância entre os diversos autores com respeito a datação de Am 7,10-17. A maioria, no entanto, compreende que este texto seja de redação posterior ao tempo da atuação do profeta no século VIII a.C.

Possivelmente Am 7,10-17 é redação posterior ao estrato do ciclo das visões. Devido à temática da rejeição da palavra profética como causa para exílio bem como seu vocabulário que a aproxima de textos da obra historiográfica deuteronomista, notadamente textos que refletem sobre a queda de Israel e Judá: 2 Rs 17,23 e 2 Rs 25,21 e Jr 52,27. Assim a narrativa parece pertencer à redação deuteronomista do período exílico ou neobabilônico, e seu propósito teológico parece ter sido atribuir a rejeição da palavra de YHWH como sendo a causa do exílio, tanto para o reino do norte como para o reino do sul.

Em seguida, ainda no capítulo quatro, analisou-se a redação de Am 8,11-12 e verificou-se que o texto também possui temática e vocabulário de período posterior ao séc. VIII a.C. Quanto a Am 8,11-12 existe maior concordância com 


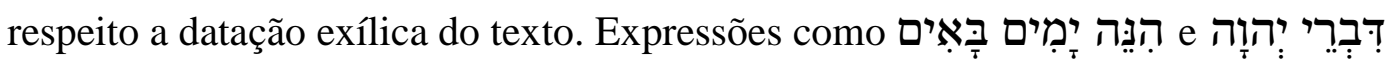
são típicas do livro de Jeremias e geralmente datadas no tempo do exílio. O tema da fome da palavra de YHWH também remete aos escritos deuteronomistas (cf. Dt 8,3). Assim, conclui-se pela possibilidade do texto pertencer ao período neobabilônico, de redação deuteronomista.

A seguir foi feita a comparação da temática dos dois textos e verificou-se que estão vinculados por uma relação de causa e efeito: A rejeição das palavras de YHWH (cf. Am 7,13) resultou na extinção desta palavra (cf. Am 8,11-12). Além disso os textos vinculam-se pela repetição lexical.

Torna-se plausível, dessa maneira, que o redator de Am 8,11-12 tenha tido o relato de Am 7,10-17 diante de si, atribuindo aquele juízo vindouro à liderança de Israel. Assim conclui-se que Am 7,10-17 precede a Am 8,11-12 e estão relacionados numa relação de causa e efeito, comprovando-se, assim, a hipótese levantada no início deste trabalho.

Por fim esta pesquisa não pretendeu esgotar o estudo de Am 8,11-12 e sua relação com Am 7,10-17 nem o tema do profeta e da palavra no livro de Amós. Há questões e aspectos do texto a serem aprofundados. Em primeiro lugar, Am 8,1112 poderia também ser relacionado com outros dois textos do livro: Am 2,11-12 e Am 3,7-8. A respeito dos limites geográficos em que os homens vaguearão em

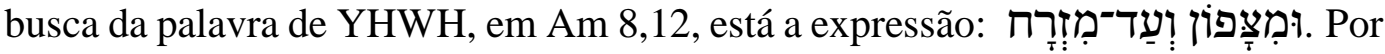
que o texto utiliza a direção norte-oriente e não norte-sul que seria mais natural? Uma outra questão é que ao longo deste estudo verificou-se que expressões presentes em Amós 8,11-12 bem como em Am 7,10-17 são típicas ou frequentes no livro de Jeremias, o que levanta a possibilidade de estudo destes textos em conjunto, seja em dimensão diacrônica (terão provindo de uma mesma mão redacional?), seja em linha sincrônica. São algumas questões abertas para trabalhos posteriores. 


\section{6 \\ Referências Bibliográficas}

\section{1.}

\section{Bíblias, Gramáticas e Manuais de Exegese}

BÍBLIA HEBRAICA QUINTA EDITIONE. GELSTON, A. (Ed.), Stuttgart, Deutsche Bibelgesellschaft, 2010.

BÍBLIA HEBRAICA STUTTGARTENSIA. ELLIGER, K., RUDOLPH, W. (ed.), Stuttgart, Deutsche Bibelgesellschaft, 1997.

COMLEY, A. E., Gesenius' Hebrew Grammar as Edited and Enlarged by the Late E. Kautzch, New York, Oxford University Press, 1910.

FISCHER, A. A., O Texto do Antigo Testamento, Barueri, Sociedade Bíblica do Brasil, 2013.

FRANCISCO, E. F., Manual da BH: Introdução ao Texto Massorético: Guia Introdutório para a BH Stuttgartensia, São Paulo, Vida Nova, 2005.

JOÜON, P.; MURAOKA, T., Gramática del Hebreo Bíblico, Navarra, Editorial Verbo Divino, 2007.

LIMA, M. L. C., Exegese Bíblica: Teoria e Prática, São Paulo, Paulinas, 2014.

NICCACCI, A., Sintaxis del Hebreo Bíblico, Navarra, Editorial Verbo Divino, 2002.

SILVA, C. M. D. da, Metodologia de Exegese Bíblica, São Paulo, Paulinas, 2009.

SIMIAN-YOFRE, H., Metodologia do Antigo Testamento. São Paulo, Loyola, 2000.

WALTKE, B. K., O’CONNOR, E. M., Introdução à Sintaxe do Hebraico Bíblico, São Paulo, Cultura Cristã, 2006.

\section{2.}

Dicionários e Léxicos

ALONSO SCHÖKEL, L., Dicionário Bíblico Hebraico-Português, São Paulo, Paulus, 1977. 
BOTTERWECK, G. J.; RINGGREN, H.; FABRY, H. J., (Ed.), Theological Dictionary of the Old Testament, William B. Eerdmans Publishing Co., 19752004.

BAUMANN, A., "כול", TDOT, vol 7, 1995, pp. 85-89.

CONRAD, J., "קָּשָ", TDOT, vol. 13, 2004, pp. 196-201.

DOMMERSHAUSEN, W., "לֶ?", TDOT, vol. 7, 1995, pp. 521-529.

JPESEN, A., “חָדזָ", TDOT, vol 4, 1980, pp. 280-290.

KELLERMANN, D., “ צָָָָא", TDOT, vol. 12, 2003, pp. 405-409.

MÜLLER, H. -P., "נָָבְיא", TDOT, vol. 9, 1998, pp.129-150.

RINGGREN, H., "נוע", TDOT, vol. 9, 1998, pp. 293-295

RUTERSWÖRDEN, U., “שַָָׁע", TDOT, vol. 15, 2006, pp. 253-279.

SEIDL,T., “רָעָב", TDOT, vol. 13, 2004, pp. 533-543.

WAGNER, S., "אָמַר”, TDOT, vol 1, 1974, pp. 328-345.

WASCHKE, E. -J., שוּט, TDOT, vol 14, 2004, pp. 528-532.

BROWN, F. - DRIVER, S. R. - BRIGGS, C. A. (ed.), The New Brown-DriverBriggs Hebrew and English Lexicon, New York, Hendrickson, 1999.

HARRIS, R. L., ARCHER, JR., WALTKE, B. K. (Ed.), Dicionário Internacional de Teologia do Antigo Testamento, São Paulo, Vida Nova, 1998.

BOWLING, A., "נוע", DITAT, pp.940-94.

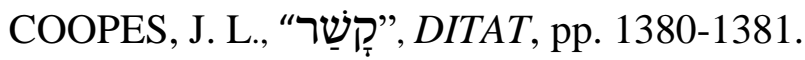

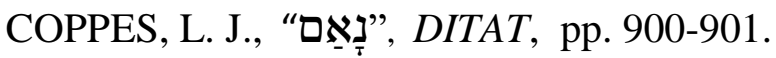

COPPES, L. J., "יוֹס", DITAT, p.604-606.

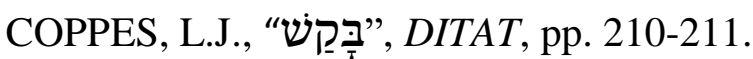

FEINBERG, C. L., "אַָָָר”, DITAT, p. 89-91.

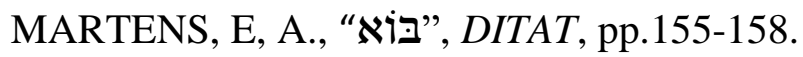

OSWALT, J. N., "כול", DITAT, p. 706.

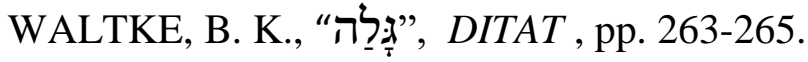

WILSON, M. R., “נטף”, DITAT, pp. 960-961.

JENNY, E.; WESTERMANN, C., Dicionario Teológico Manual del Antiguo Testamento, vol. 1-2, Madri, Ediciones Cristiandad, 1978.

DELCOR, M.; JENNY. E., “שָׁלַח", DTMAT, vol.2, pp.1142-1149. 
GERLEMAN, G., “בקשש", DTMAT, vol.1, pp.483-486.

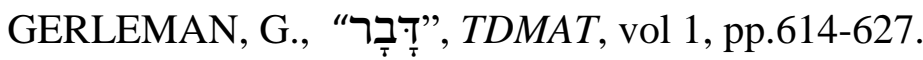

GERLEMAN, G., "מצא", DTMAT, vol.2, pp.1256.

JEREMIAS, J., "נָבְביא", DTMAT, vol.2, p.22-46.

VETTER, D., “חזה”, DTMAT, vol.1, p.744-750.

VETTER, D.,"הנה"ה", DTMAT, vol 1, pp.705-710.

WESTERMANN, C.; ALBERTZ, R., “גלה", DTMAT,vol.1, pp.596-606.

MCKENZIE, J. L., “Terremoto”. In: Dicionário Bíblico, São Paulo, Paulinas, 1983, p.924.

VANGEMEREN, W. A (Org.)., Novo Dicionário Internacional de Teologia e Exegese do Antigo Testamento, vol.1-4, São Paulo, Cultura Cristã, 2011.

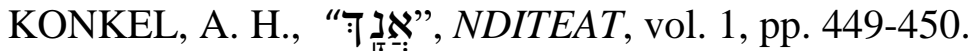

HARMAN, A., "Partículas”, NDITEAT, vol.4, pp. 1024-1038.

COLLINS, C. J., "ששלח", NDITEAT, vol. 4; pp.119-124;

AITKEN, A. T., "שמע", NDITEAT, vol. 4, pp.174-180.

KONKEL, A. H., “כול” , NDITEAT, vol. 2, pp. 614-615.

NAUDÉ, J. A., "חזה” , NDITEAT, vol. 2, pp. 56-61.

SOUTHWELL, P. J. M., "Betel”, NDITEAT, vol. IV, p. 434.

VERHOEF, P. A., "Profecia”, NDITEAT, p. 1068.

GRISSANTI, M. A., “אָדָדָה”, NDITEAT, vol 1, pp. 262-267.

HOLladAY W, L., Léxico Hebraico e Aramaico do Antigo Testamento, São Paulo, Vida Nova, 2010.

MURAOKA, T., A Greek-English Lexicon of The Septuagint, Leuven, Peeters, 2009.

MURAOKA, T., A Greek - Hebrew/Aramaic: Two-way Index to the Sepruagint, Leuven, Peeters, 2010.

ISIDRO PEREIRA, S.J., Dicionário Grego-Português e Português-Grego, Braga, Livraria Apostolado da Imprensa, 1998.

LIDDELL, H. G.; SCOTT, R., A Greek-English Lexicon, New York, Oxford University Press, 1996. 


\section{3.}

\section{Obras em geral e comentários}

ABREGO DE LACY, J. M., Los Libros Profeticos, Navarra, Ed. Verbo Divino, 1993.

ALONSO SHÖCKEL, L.; SICRE DIAS, J. L., Profetas, vol.2, São Paulo, Paulus, 2002.

ANDERSEN, F, I.; FREEDMAN, D, N., Amos: A New Translation With Notes and Commentary, New York, Doubleday, 1989.

BARTHÉLEMY, D., Critique textuelle de l'ancien testament: Tome 3, Ezechiel, Daniel, et les 12 prophètes, Fribourg Suisse Vandenhoeck \& Ruprecht Göttingen, Éditions Universitaires, 1992.

SMITH, B. K.; PAGE, F. K., Amos, Obadiah, Jonah, vol 19b: An Exegetical and Theological Exposition of the Holy Scripture, Nashville, B \& H Publishing Group, 1995.

BOVATI, P.; MEYNET, R., Le Livre du Prophète Amos, Paris, Les Éditions du Cerf, 1994.

BRUEGgMANN, W., Teologia do Antigo Testamento, Santo André, Academia Cristã : São Paulo, Paulus, 2014.

DELL, K. J., “Amos and the Earthquake: Judment as Natural Disaster", p.2, In: HAGEDORN, A. C.; MEIN, A., Aspects of Amos: Exegesis and Interpretation, York Road, T\&T Clark International, 2011.

FERNANDES, L.A., O Anúncio do Dia do Senhor: Significado Profético e Sentido Teológico de Joel 2,1-11, São Paulo, Paulinas, 2014.

FOHRER G., História da Religião de Israel, Santo André, Academia Cristã : São Paulo, Paulus, 2012.

GARRET, D. A., Amos: A Handbook On The Hebrew Text, Waco, Baylor University Press, 2008.

HASEL, G. F., Understanding The Book of Amos: Basic Issues in Corrent Interpretations, Michigan, Baker Book House, 1991.

HADJIEV, T. S., The Composition and Redaction of the Book of Amos, Berlin, Walter de Gruyter, 2009. 
HUBBARD, D, A., Joel e Amós: Introdução e Comentário, São Paulo, Vida Nova, 1996.

JACOB, E.; KELLER, C. A.; AMSLER, S., Commentaire de L'Ancien Testament: Osée, Joël, Amos, Abdias, Jonas, Paris, Delachaux et Niestlé, 1965.

JEREMIAS, J., Amos: Traduzione e Commento, Brescia, Paideia Editrice, 2000. , The Book of Amos: A Commentary, Louisville, Westminster / John Knox Press, 1998.

LIMA, M. L. C., Mensageiros de Deus: Profetas e Profecias no Antigo Israel, Rio de Janeiro, Ed. PUC - Rio: São Paulo, Ed. Reflexão, 2012.

SCHREINER, J. (Org.), O Antigo Testamento: Um Olhar Atento para a sua Palavra e Mensagem, São Paulo, Hagnos, 2012.

LOHFINK, N., "Balanço após a Catástrofe: A Obra Historiográfica Deuteronomística", pp. 259-274.

FÜGLISTER, N., "Entusiasmado por Javé: Arauto da Palavra”, pp.168-195.

MCCOMISKEY, T. E., Hosea, Joel and Amos, in: The Minor Prophets: An Exegetical and Expository Commentary, Vol.1:, Michigan, Baker Book House Company, 1992.

PAUL, S. M., Amos: A Commentary on the Book of Amos, Minneapolis, Fortress Press, 1991.

RAD, G. V., Teologia do Antigo Testamento, São Paulo, Aste / Targumim, 2006.

RÖMER, T., A Chamada História Deuteronomista: Introdução Sociológica, Histórica e Literária, Petrópolis, Vozes, 2008.

RUDOLPH, W., Kommentar zum Alten Testament: Joel, Amos, Obadja, Jona, Gütersloh, Gütersloher Verlagshaus Gerd Mohn, 1971.

SCHART, A., Die Entstehung des Zwölfprophetenbuchs. Neubearbeitungen von Amos im Rahmen Schriftenübergreifender Redaktionsprozesse, Berlin / New York: W. de Gruyter, 1998.

SCHMID, K., História da Literatura do Antigo Testamento, São Paulo, Edições Loyola, 2013.

SCHMIDT, W. H., Introdução ao Antigo Testamento, São Leopoldo, Sinodal, 1994. 
SICRE, J. L., Profetismo em Israel: O profeta, Os Profetas, A Mensagem, Petrópolis, Vozes, 2008.

SIMIAN-YOFRE, H., Amos: Nueva Versione, Introduzione e Commento, Torino, Paoline Editoriale Libri, 2002.

SMITH, G. V., Comentário do Antigo Testamento: Amós, São Paulo, Cultura Cristã, 2008.

STUART, D. K.,: Hosea - Jonah, vol 31, World Biblical Commentary, Dallas, Word Books, 1987.

SCHWANTES, M., A Terra Não Pode Suportar Suas Palavras (Am 7,10-17): Reflexão e Estudo sobre Amós, São Paulo, Paulinas, 2004.

SWEENEY, M. A., The Twelve Prophets, Colegeville, Liturgical Press, 2000.

VAUX, R. de, Instituições de Israel no Antigo Testamento, São Paulo, Vida Nova, 2004.

WESTERMANN, C., Basic Forms of Prophetic Speech in the Old Testament, Cambridge, The Lutterworth Press: Lousville, Westminster / John Knox Press, 1991.

WESTERMANN, C., Os Fundamentos da Teologia do Antigo Testamento, São Paulo, Ed. Academia Cristã, 2011.

WOLFF, H. W., Joel and Amos: A Commentary on the Books of the Prophets Joel and Amos, Philadelphia, Fortress Press, 1977.

ZENGER, E., et al., Introdução ao Antigo Testamento, São Paulo, Edições Loyola, 2003.

\section{4 .}

Artigos, dissertações e teses

BULKELEY, T., "Amos 7,1-8,3: Cohesion and Generic Dissonance", In: Zeitschrift für die Alttestamentliche Wissenschaft, vol. $121 n^{\circ} 4,2009, p 515$ 528 .

COIMBRA, A. S., "Debate em torno da redação e composição do livro de Amós: propostas fundamentais para a teoria da criação coletiva de Am 6,1-14”, Tese 
de Doutorado, São Bernardo do Campo, Universidade Metodista de São Paulo, Faculdade de Filosofia e Ciências da Religião, 1987, 427 p.

DEL BARCO, F. X., Profecía y Sintaxis. El Uso de Las Formas Verbales em los Profetas Menores Preexílicos, Tese (Doutorado), Madri, 2001, 368 p., Universidade Complutense de Madri.

DELL, K. J., "Amos and the Earthquake: Judment as Natural Disaster", p.2, In: HAGEDORN, A. C.; MEIN, A., Aspects of Amos: Exegesis and Interpretation, York Road, T\&T Clark International, 2011.

DEVER, W. G., "A Case Study in Biblical Archaeology: The Earthquake of 760 B.C.E.”. In: Avraham Biran, vol. 23. Jerusalem: The Israel Exploration Society / Hebrew Union College - Jewish Institute of Hebrew Union College - Jewish Institute of religion, 1992, pp. 27-35.

ERLANDSSON, S., “Några exempel på Waw Explicativum”, In: Svensk Exegetisk Årsbok, vol 41-41, 1976, pp. 69-76.

LEWIS, J. P., “A Prophet's Son (Amos 7:14) Reconsidered”, Restoration Quarterly, vol. 49, n 4, 2007, pp. 229-240.

LIMA, M. L. C., “Am 9,11-15 e a Unidade do Livro dos Doze Profetas". In: Atualidade Teológica, Ano VII, fasc. 14 (2003), pp. 182-199. ., "O juízo para Israel / Judá nos livros proféticos”. In: Atualidade Teológica, Ano XII, fasc. 30 (2008), pp. 317-334.

NOBLE, R. N., "Amos and Amaziah in Context: Synchronic and Diachronic Approaches to Amos 7-8", The Catholic Biblical Quarterly, vol. 60, n 3, Jul 1998, pp. 423-439.

PERNANBUCO, M. N., "Os textos doxológicos de Amós no contexto do livro, em especial relação com Am 1,1: 8,8 e 9,1: a relevância do terremoto na mensagem do livro", Dissertação de Mestrado, Rio de Janeiro, Pontifícia Universidade Católica do Rio de Janeiro, Departamento de Teologia, , 2012, 116 p.

RÖSEL, H. N., "Kleine Studien zur Entwicklung des Amosbushes", Vetus Testamentum, Leiden: E. J. Bill, vol.43, pp.88-101, 1993.

TUCKER, G. M., "Prophetic Authenticity: A Form-Critical Study of Amos 7:1017', Interpretation: A Journal of Bible and Theology, vol. 27, $\mathrm{n}^{\circ} 4$, outubro / 1973, pp.423-434. 
VIBERG, A., “Amos 7,14: a case of subttle irony”. In: Tyndale Bulletin , vol.47, $\mathrm{n}^{\circ}$ 1, 1996, pp. 91-114.

LANDY, F., Visions and Poetic Speech in Amos, Hebrew Annual Review, vol. 11, 1987, pp. 223-246.

SNYMAN, S. D., "The land as a leitmotiv in the book of Amos", in: Verbun et Ecclesia, vol.26, n², 2005, pp.527-542. 